University of Louisville

ThinkIR: The University of Louisville's Institutional Repository

Electronic Theses and Dissertations

1935

\title{
Food and drink of Elizabethan England as reflected in the literature of the age.
}

Elizabeth Frederick Baggerly 1901-1988

University of Louisville

Follow this and additional works at: https://ir.library.louisville.edu/etd

Part of the European History Commons, Literature in English, British Isles Commons, and the Social and Cultural Anthropology Commons

\section{Recommended Citation}

Baggerly, Elizabeth Frederick 1901-1988, "Food and drink of Elizabethan England as reflected in the literature of the age." (1935). Electronic Theses and Dissertations. Paper 1672.

https://doi.org/10.18297/etd/1672

This Master's Thesis is brought to you for free and open access by ThinkIR: The University of Louisville's Institutional Repository. It has been accepted for inclusion in Electronic Theses and Dissertations by an authorized administrator of ThinkIR: The University of Louisville's Institutional Repository. This title appears here courtesy of the author, who has retained all other copyrights. For more information, please contact thinkir@louisville.edu. 


\title{
UII VERSITI OF LOOISVI LE
}

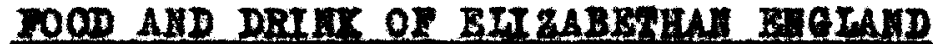

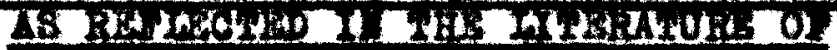 tisats}

\author{
A Berextation \\ Subutted to the Faoulty \\ Of the Gradnate Bohsel of the Jaivereity of Loularilie \\ In Partial Molfillmont of the \\ Regalromente for the Degree \\ of unter of Arte
}

Dopartuont of Inglioh

by

BITZABREH FREDBRT CX BAGOBRT

1985. 


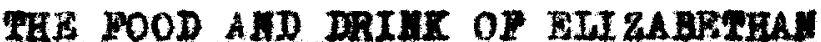

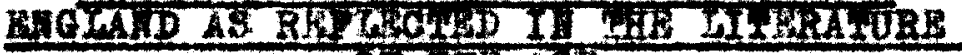
D) HIS AGE. 
Chanter.

Pase.

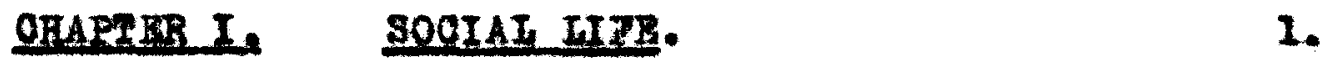

OHAPRER IX, ZOOD OP PHP AGR OF BLTZABPEA.

QHAPTER III. DRIUK OF PHH AGS OF BIIZABBTH. 78

CHAPTER IY, YOOD AID DRTEX AS A EARE OF 100

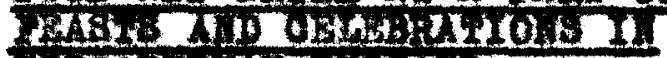

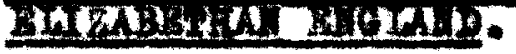

concrosioy.

108

BTBHIOCRAPHX.

118 
CREPT I I.

Boctal IIE 


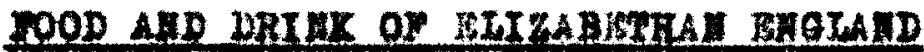

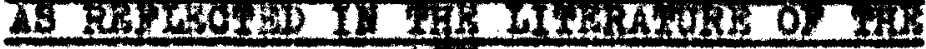

Ale.

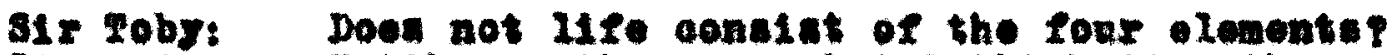

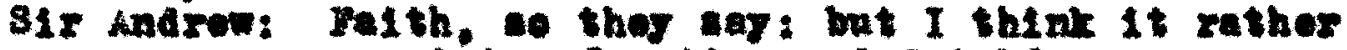
oonusite of catibs and canting.

(rwalish High, II, i11, 2I).

CHAPRAR 1

SOCTAL LIF

Food and drink have alwaya boen of mafor Interest to manking, but a andy of the I1terature of KIIsebothan inglana roveale an abeorption that is alwont unparallelod. However, the Britioh trom the early age of history hare beon alstingulahed for hoarty appotitee: provielone in elxteenth oentury Rngland were both plentitul and chop. ${ }^{2}$ whioh racte in oombination with the extraordinary hourlehing of a realiatio drame. may cooount for the Innumereble allusions to eating and arinking.

1. F. D. Trmi11 and J. S. Kann, SogLa Bagland. London, 1902, Vo1., $3, p, 641$.

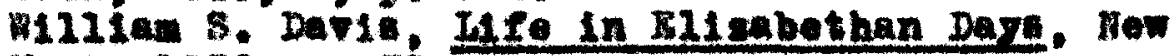
Xork. 1980, 0.79 


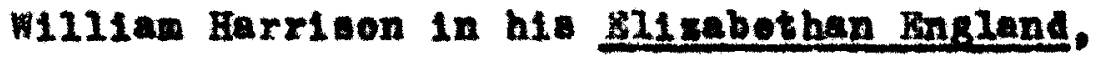
published in 1677, thue nalvely acconate for the Inaty appetites of his coantryaen:

The aftantion af our region. 1 ying near nato the north. loth canes the heat of our etomehe to be of somerbat greater fores: therefore onx bodles do olave a It ie nore ample nonriabment than the Inhabitants of the hotter roglons are coonetemed withal, whose algeative foroe ie not altogether es rehenont. becauas tholr intermal hoat is not to atrong an onre, whioh is rept in by the coldnes of the air that fron time

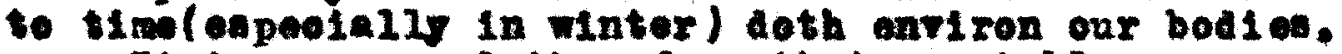

It 1 a wartel therefore that our tables are ortentines wore plentifully garaished than those of othex nation. and this trade hath oontinned with no even elnee the rexy beginning. 1

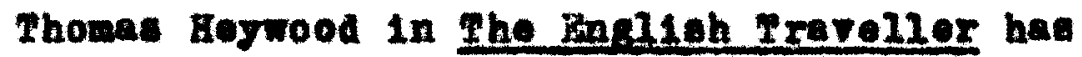

written along the ane lines in the apeoh of young ceral1ne:

A. I obaerte. vach sereral olime, for objeot. Fare, or neo, Afroral Athin lteelf for all of thebe What ia most pleasing to the man there born: Spain, that jields sent of food, afforde the nation A pariinontops stomah, whereas our appetites Are not content bus with the large exoese of a tull tablo; whore the pleasing'et fruite Are found most frequent. there they beat content: Where plenty how. It aske abundant reaste; Yor co hath provident leture dealt ith all. (I. 1. 165$)$

Love of rood and arink was a herltage Irem the 8axone, who were notorlougly intemperate at the teble. It 1. Intereating to note that moh of the food of

1. W121an Harrison, Ellsabethan Fngland, Tondon, 1876. p. e4. 
Blizebethan ingland was diatinotly gedieval in oheraotor and that many of the same dishos had been eaton in anolont Gresoe and Rome. Certainls the Romant on thelr conquest of Britain left their imprint for all time on inglish cookery. Soob typloally linglish dishes as roast boar, roast p1B, weat ples and puddinge were eaten in Groece and Reae. Inkewiae porridge bad been ational dinh of the Romans until whoeten bread was Introdnoed frow Athona. Herbe wore thon as laviahly anod for flavoringa; regetables and moats wero witrosted in tho samo fashion; snd honer dispensed in the sano unrestrained amonnte as was ougar in Blisabeth's time. Too mamerons to mention are other andiart 1 a.

Willaz the Conqueror, whe was somothing of a gourmot for his day, Imported his entire kitahen tafe and consequently bequeathed to Finglish cookerg sone of the refinements of premoh colsinet the Mormens were netrualiy more temperate then the Sexons, but with the rapid agduilation of the two peoples, this restraint soon disappeared. Throughout the medioval period leasting was nothing lase than giuttonone.

Daring Tudor times there were a great many ohanged In the diet, particalariy in that of the well-to-do Fngliehwan. In Henry VII' KeIgn, Angland, Alwage more than normaly ingular, had eateblished oontaot with the continent, and honoe had becomo a new market for forolgn products. Elisabethan Angland wa rloher than erer before and there-

1. K. B. Syage, Soctel Life in Feland, Hew York, 1906, p. 65. 
fore was ablo to enfoy the onltivated laxuried that oone with eopnondo profperity. The rojagen of exploration and discovery, the oponing ap of new trade routes, and the general extenat on of finglith comeroe, all brought adranoes In domentio rafinement whioh oansed wariced obanges in the social 11 e of the poople. 1

Fradesmen had been a little alow in acoepting the changed oondition. The firet forelga luxaries introdnood in the fifteenth oentury had been odied "anthrifty warea" and It is reoorded thet a weluh port refused to take a oargo of apples. "rabblah that would bo wasted in week," in exchange for broadoloth and wool, "the more durable wares of the oountry. 2

How extravaganoes found their way into the country. -trange foods fron dietent lande, amongat whloh were turrers from hoxdoo, potatoes from ch111, aprioote, Iemono and tomstoes, all of whioh oontributed to the national mena. since an interest in travel bad been atimulated, the retumed rojager brought howe with hin an aequired taste for forelgn foods and new fashions whioh set their mark on the soolal 11fe of the tire. And, natnrally the oldera, at has been oustomary with elder: alnoe timo immemorial, lookod upon those changed and feared that acmorallsation of the national fibre wonda

1. H. D. Traili, op.e1t., P. 212.

2. Ibid. p. 211. 
enone. I Will1am Harrison warned thet Pagland would bo ruined by "the nonal gending of noblemen's and meen gentlowen'. and Into Italy, from whones theg bring how nothing bet wore atholam, infidelity, Nolont converation, and embitioue and proud behaviour, wheroby it aoweth to pase that they return far woree men than thej went out." 2 Thoma Neahe in The Onfortunete Fraveller oleiw that "Italy makea eur jonge master a oourtior.... he bringa the art of oplouxieing. $" 8$

The latrodnetion of laxaried into ragland and the returned traveller with hie Continentel pollob did not esoape the satipio darte of the rritere of the poriod. "The follted of the fabkionable had for yeare been jealounly watohed by the Purltan. How the satirist and dramatist both turned to the attack. wen whose temper was that of the mida le olase Knglistanan - Greone, Iashe, Lodge, Chapman, Ha11, Dome, Maraten and Jonson.

Sald Ben Jonson of the traveller in Grathia's

Rerels:

7. doth learn to mske atrange ganoes, to eat anchortes, moneront...........

$$
\text { (II, 1. 264). }
$$

The tooth-plok and fork in partionlex were

1. H. D. Tra111, op.01t., p. 502.

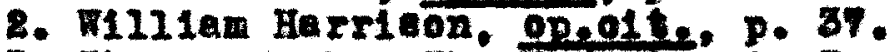

3. Thowas kathe. The Untortanate Irareller, Boston and Hew York, 1920 , P. 96.

4. Char los Reed Baskorvilie, Bnglieh Flemente in Jone on's Berly Comedr, Austin, Texas, 1911, p. 19. 
elngled ont for all maner of ridicale. In those day. whon olennilness of body was at ittle thought of as wae the sanitary cond 1 tione of the house, the afrent of the toothplok was really a narl of adrance in ofviligation. Tooth-piok were ostentationsly carried. Often they were mede of gold with jeweled cenes. Sometimes the mat bave been factened with ribbene as in this extract from Besmont and Flotoher' The Foman-Hater:

Ine10: I woula not have appeared to rou thue ignorantly attired. without a toothplok 1 a ribbana. $(7,1,101)$.

To plok one'e teeth in public beasmo a curely tho wark of a gentlenga a to tall the rabbish set in rogue by foly'a Bephnea." 1

In Yonelear Thomge by Beanmont and Flatober. Sebastian cries ont in bitternede againet travel that has anced his con to "eat with plaks."

47 grand onxee

Hange or the head the thas transform'd the : ravel: (I. 11, 481$)$

In Gratain Rerele by Joneon there is this aketoh of a trave11er:

He that is with hin is Amorphna, A travelier....... He walica most commonly With alere or tooth-piok in hie month. He operk a 11 orean-akimed (attectod). (II. 1. 200).

1. Henry Thew Stephenson. Elizabethan Poople, Hew York. 1912, 1.866 . 
A180 in The Honest Man'a Fortune by Beawnont and Flotoher there 10 thia Indetment of tratel:

You have travell'd like fidrler to make faoes, And brought home nothing but ase of toothpiek. (V, 111, 244).

It it generally enpposed that one Thomas corrat introduoed the fort into bingland. In his cradities, pab11shed in 1556, he gives an socount of the use of the fork In Italy. "The Italian oannot by any mean to bare his dish of meat touohed with IIngers, ceeing that all mon's Pingere are not alike olean!" Thomes had to ondure the jtbes of his untravelled fellowe whon ho used his fork, for exen hit friond oonelderod 1t forelgn affeotation. One elergrman preached against the we of forla "as belng an Inerit to Providenoe not to toreh one's meat with ons's eingers: ${ }^{2}$

In Wouinger's The Great Date of Morenoe, Bansarro, the deke's Favorite, cags:

I have all that's requist te

To the making up of a alghior: ay oproce rafl. 4 hooded oloak, long stooking, and paned bose, 4 case of toothpiers, and oilror fork. To convey an ollve noatly to my morth. (III, 1, 486).

Ben Jonson also flonte the "fork-earting

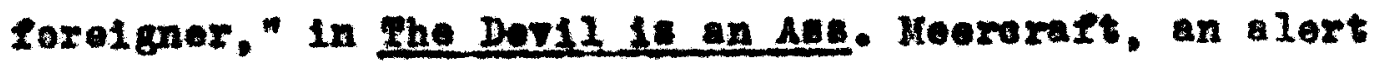
Blizebethan brainese-ren, Inquitres of elithead and sledge:

1. Wm. J. Nolfe, Shakespeare the Bor, Wew York, 1896, p. 65. 
Have I deserved thl from you? for all

4 pains a conrt, to get jou each a patent. Q11 thead. For what?

Meereraft. Upon ay projeat of the forke.

a11thead. Forke! What be thert

Heeroraft. The laudable nee of forka,

Brought into cueton hore a they are in Italy

To the sparing of naptins.

(7. 111, 136-137).

In Volpone by Jomen, S1r golot1ak-Would-Be giree

adioe to Reregrine to:

..... learn the nee

ind handing of your ellver fork at meale, The metal of your glaes. Those are main matters With jour Italian.

$$
\text { (II, 11, } 275) \text {. }
$$

In The gaeen of Corinth by John Pletoher, the

Totor saya:

Tour $T$ beard is the fashion

hind twifold doth exprese th' onamoured oourtior A. tall as jour fork-oarting traveller.

$$
\text { (IV, 1. } 186) \text {. }
$$

In epito of the Iarish hoopltality that ia apparent in the literatere of slisabeth'a time, the elders need to bemean the paseing of the entertainmont of the old dayt. "The wealthier country gentlemon of rnightly rank and the oone1derable tunetionaries manteined, a la well known. a style of housekeping to whioh at preant wo have absolutely nothirg that bears the leat reneablanoe. Even in the preen's days, and not in the latest of then, the death of Edward barl of Derby was lamented a patting an end to iold Bngliah hoeptbality: ' but from what we know of the way of 
thoes who survived him, there was not moh so oomplain of." 1

It is trae that daring the Tucor perlod somo ohanges had taken place. Perhape o little of the agnifioenoe, as woll as the unificence, of the medieval tablo had pased anaj. Sereral inpritable canes had oontributed to the change, not the least being the deoay of foudelien, the apread of the remirieting and fogless epirit of paritanisa, and perhap the breaklag-np of many how-keoping tradition,

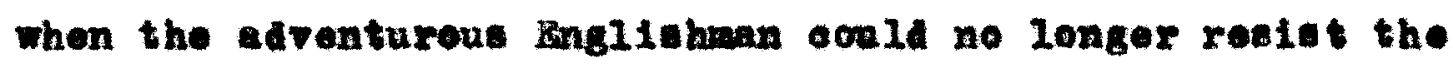
oall of the sea. The abolition of a large number of foast daje efter Henry VII' aeparation from the Cathollo obnrob had reduced fort1rity to tone slight extent, but considering that feast days were still more than "seren and twenty." 2 BLsaboth' Heland was et111 mery land.

In spite of these fow restraining influenoes. honpltality wal contimued on an anbellavably prodigal soalo by the wealthy families of the realn, with the guen herself setting the exumple. For Blisebeth like bor father was paneionately addoted to entertaimant and one enjoged nothing so whoh as paping viflta to har nobles.

The finglish love of eating snd drinking it no more tradtional than a fondnose for prosase hospitality. Bays Ben Jonson in his Peotacter.

I had rathee want meat, than want gueets; ofpeolally if they be oortig guefte.

$$
\text { (x, } 1,429) \text {. }
$$

1. H. D. Traj11, op.01t., p. 638.

2. William Harrison, Opaolt.. p. 78. 
"Poreignere llege that the oneen's abjeote axe always glad of the loaft exouse for 'BIVIng a foast to a otrenger.' 'They would rather (wrote Venotian ambangedor) gire five or alx ducats to provide an ontortalnment for a person, than gire groet to asist him in any algtrese.' In the country, everyone, high or low, wat forever anking in greete to hie table. Fable-folk were constantly exohanglng 21tt1. present: of oatablos- oake, padding, and the 11ke....... One very wealthy squire in Mottingham had shoer paselon for hospltality. He began his Christmas on 111

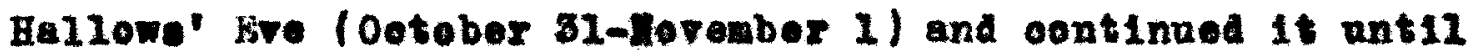
Cand lemes (rebruary seoond), daring whiob interval any wan wae permitted to atay and feast for three daye withont being aeked 'whenoe he one or what he 16.' For each of the twelve ang before Christuas, the hospltable equire allowed hie greete fet ox and other provielong in proportion."il Th1s generous sopl was like unte the hout in Boaunont and Flotoher' Bollo. or The Bloodr Brother:

......... rojal gent loman indeed, He will wake the ohimnios amoak!

$$
(I I, 11,258) \text {. }
$$

Heywood has thus sumbed ap the matter in The inglieh Trevellex throngh the speech of the loquotone clom:

I'll stand to 1t. that in good hogpitality there oan be nothing found that' 111: he that'a a good house-keoper keepe a good table, a good table is nerer without good toole. good atoele seldom without good guests. good guedte never whout good oheer, pod obeer

1. W. S. Dav1., 0p.01t., pp. 71-7R. 
sannot be without good atomahe, good atomeohs Wthout good digestion, $800 d$ digention keops man in good hoelth; and therefor all good peoplo that bear good minds, as rou love goodnese. be sure to keep good reat and drink in rour houses, and rou thall be called good bax, and nothing can oome on't but sood, I warrant jow.

$$
\text { (I. 11, } 268) \text {. }
$$

Hassinger in The Onnaterel Combet alao has oonsidered the subjeot, with the warning that hospltal1ty ahould not be abused;

Boanfort, I love table forniah'a with fell plenty.

And etore of friende to eat it: bat with thie cantion.

I would not have my house a oomen inn,

I muit not have ay board peater'd with shadowe, wthont invitement.

$$
\text { (III. 1. } 168 \text { ). }
$$

The term "Ghadow" can be anderatood by reforring to Plutaroh, who expleing that 1 was a mark of politenese to lot a guest know he was at liberty to bring a friend or two to meals: a permiseion nometimes abrated. These

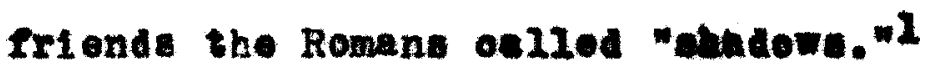

Intertaiment was mere foasible in the country than In the olty, where living quarters were not to anple or provialon so attainable. Som laea of the oulinary efforta oxpended upen the oovntry gontleman's meals oan be realised by reading The Bnglah Hongenfe by Gervase Harkhem, writiten In the laft peare of the alxteenth oontury. Wrichan deg1. Phillp Maseinger, Plate, London, 1818 , noto p. 165. 
oribes a "huble Ieast or an ordinary proportion whioh anj good man keep in his fanily for the ontertalnmont of bis true and worth friends." The "bumble feast or ordinarg" Inoludes "alteen alshes of meat that are of bebstance and not enpty, or for show." To these "alxteon tril a1shes," he adds "sallote, Iricanees, quelque choee, and dovied paste, and wany dished more, whioh wake the full serrice no 108 ghan thirty-and-two dibhos."1 And this was moal for the oannel greatl

The cotting of exah tables foll upon the shouldere of the conntry houlewife. "For hoapltality to all who chose to demend it, to the loweat as well at the highest In the land wa the flrat pirtae to be preoticed by the oovetry houlewife. In the days when there were fow inns, none in oonntry places fit for the acoomodation of ladies. when roads were bal and coabhes heavy, and whon soreral nights had constantly to be opent in the oouree of a olinglo jonrnes, a Iriend' houes was the natral halting place. And Iriends were by wo meane the only visitors. offleide of ell sorte, traveling the conntry in the coaree of their antied, expocted to be entertained in the larger houses. Snites of room wore enpecielly bullt for vititor, who, if they were people of eny consequenoe, brought in thoir train an imonse maber of cervante and rotalnom o" 2 The visite that queen Blisabeth was wont to pay

1. Rose Bradiey. The Country Housewfe of the 17th and 18th Centuries, London, 1912, P. 74.

2. IbId, 26 . 
her oourtiers often ontalled spoh olaborate preparatien as those at Blrothan prior to her atay with the Barl of Hertford. As the Rarl's wankion was too mall to honse the queen's retime, the following ballainge were ereoted eapoedally for her injeaty:

A room of estate for the nobles, with a withdrawIng plaoe for her vajesty: the ontaldea all oovered Ith boeghe, and olustere of ripe hesel unte, and In1de with arras. the root with worica of Iry leaves, the Moers with aweet horba and groen rubhoa. Mear to this wore the apeolal offiees: the spleery, lardery, ohanalexy, wino-oeliar, ewery, and pantry, ail of whioh were tilod. There was alae made areat bommon buttery; a pltoher howes: a large pastery. Ath fire now orens, some of them rourteen foot deop: a great kitohen, with four ranges and a bolling plave; nother great kitohon for all oomers: bolling hease for the great boller; a roos for the copllery, and another for the oooket lodginge..........

Bon Joneon in an adereas to penehuret thus onlogices the acoonplishod hosteas whose house was kept perpetrally at enoh a high atencard of perfeotion that the queen oonle pay a surpriae vialt to her in hor absenos and find ororything in order for royal entertainmont:

Hor linen, plate, and all thinga right Thongh ahe was far: and overy roon wge droet Ae if she had expeoted suoh guest.2

Besides a constant opervision of the larder. kitohene, and dining ha2l, the preasering of fralts, making of oonfections, arying and salting of meats, the making of wine and the brewing of ale, the ountry housewife attended

1. John Lyly, Complete Worle, 0xtord, 1908, Vol, 1, pp.432488.

2. Rose Bradley, Op.e1t.,P. 66. 
to the ooneooting of modiolnal bererages furni whed by the berb garden. Her 11 fe was a bugy one.

Hospitallty was not alene reserved for the great housed. In the mumbleat oottage, the people were willing to share their simple fure with triends. In the pitah of Edmonton, the work of John Ford, Jeoman spouka:

When he oomes he hall be woloose to bread, beor, and beef, Jooman's fare; we bave no klokehawe:

fall dishes, whole bellstwie....... (1, 11, 187$)$

Margaret, the roeper's daughtor in Greene's Yriar Baon and Ixiar Banngy extends houpltality to Iaog:
Well, If you chanee to com by Freseingtield, Hake but a atep into the Xeeper's lodge: And anoh poor fare as woodmon on afford, Butter and oheowe, orean and fat ronison, You shall have atore, and woloome therenithal. (1, 112, 241).

Wh1 ie the unbldden guest was alwage weloomed at mea 1*, In earlier times it was the ouston to bring a atool on acoont of the coaraity of farniture. When a ohar is offored to the Bake of Breohian in the White Deril by wobster, he cays:

Forbear your kindneos; an unbldden guent should tratel as Dateh womon ge to ohnroh, Bear thole stoal with them.

(note p. 181-inaelnger-the vmataral Combat).

Likewi ee in The Ummatnral Oombat by Maseinger:

$$
\text { Bring their ôoir with them. }
$$


The maln room of the manalon was atually the great ball. whioh often served dining-room, drawing-roon and as alace of Iestivity. When mealn wero served, tablce were brought in or else taken down fron thelr plaeen agalnet the wils. These taibles consiated of leares hinged togethor

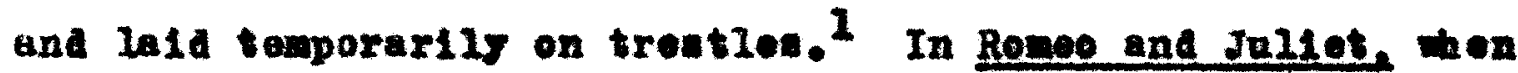
more room is noeded for danolng, Capnlet orders:

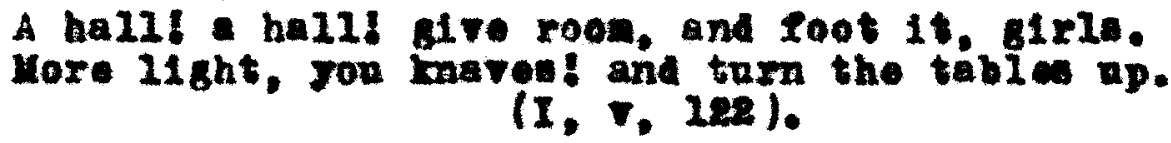

The 2 loors were carpeted with deep pile of ruehed which were ordinarily renowed only yearly. In sumer when the odor of new hay and fragrant boughe filled the hall, onoh ourposing wot not have beon unpleasant, but in midwinter and early epring, when a doponit of dust, grease, deoaged sood and all corte of rubbiab had joinod the racher, the melange wat have been most uneavory. Meniale wlelaing the "rolding knife," found the noer tempting and convenient disposition for table refune. 2

The family of Sir Thomal Hore was known for stertilng innovations. The dary of Mrgery, danghter of S1r Thome, Indieated that the Mored were mbienleally in adranoe of woat of thatr oountrymen. She wrote:

Gonollinf ank' leare to toe Eranmas, hil signet ring, which he handed down to hin. In paselng it baok, Wilitan, who was co ocoupled in carving a orene, handod 1t 800 negligentile, that it foll to jo ground. I nover daw oroh a face as Braanis made when 'twas plaked

1. Henry Thew 8tepheneon, Shakespeare's Londen, How York, 1905, p. 17.

2. Beaniont Fletoher, The Coxoomb, Bainburgh, 1812, I, 1, p.34). 
ont fron ye rushes. Ana jet oura are renowed alnost cayl1. whiob wante think over aloo. 1

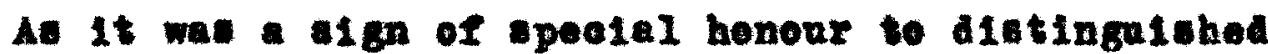
vistors to renew mahes. Geon mahes beeame proverbial

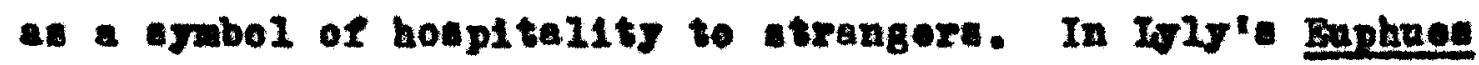

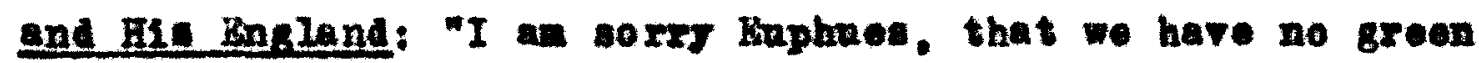

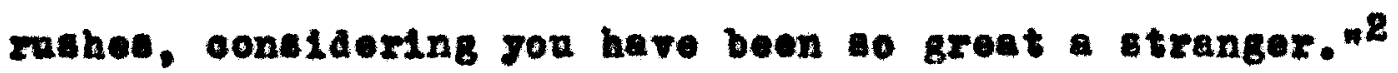

Beapuont and Mlotoher in Yalentinien refer to thic onatom as followe:

Ronot, Lales, rushes.

Rushes as green as enmer, for this etranger. (II. $\%, 410)$

In John Wobatex's Woatrare Hoe:

Here be rushes! (II, 11,96$) 0^{8}$

In the Ellabethan houtehola, the head of the santis no longer at upon a de14. but at the ond of a long table. Slnoe the Jorman conquest a bege entt oeliar placed ad-way of the table, serred as a boundery of alstinotion In table seating." "Itke a alsposing angel at the bay of Jugment. the elt aith oparated the coolal abeep Irom the coolal goats." 5 Abore the alt eat the rently. the stewara, the ohmplein, the gentleman uahera and the ladies-1n-waiting.

1. J. 0. Andrewe, Breaktant, Dinner and gee, viewa Clase1-

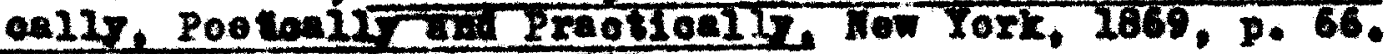

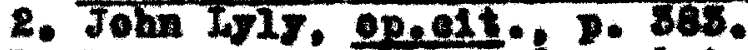

8. Rushes are atro reterrod to in the Taming of a Shron.

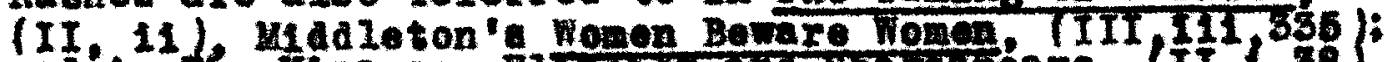

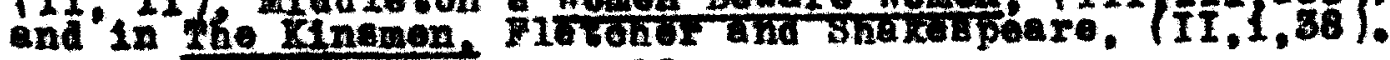

4. H. B. sjage, on.alt., p. 80.

5. W. S. Dav1., Op.o1t., p. 74. 
BeIow sat all the house servants not coneerned with the gerving of the meal, the tonanta, any waytarere who clatned hospitality, or ans pooxer relations. Those below did not presume to talk with those on the other alde of the hage calt dioh. Mataraily, there wat a differonoe in the food and arink cerred on the opponited sided of the oellax.l

There are several reforenoed in the playe to this Forman oustow of seating by the salt. In Grathia's Revels by Jonson, Meroury say of courtier;

He nover arinke below the salt.

$$
\text { (II, 1, 259). }
$$

In The Heneet Whore by Dokkex:

Plague hin, wet hil beneath the alit and let him not touch a bite till overy one bas had his fril ont. (Paxt I, 1I, 11).

In The o1tr lacen by Maninger:

He 1 th beneath the ealt, an objeet of conterpt.

$$
\text { (I. 1. 402). }
$$

M1108 in Exlar Baoon and Mriar Banger majs:

.......their cheer ahall not be great, and therefore what akd11 where the salt atand, before ox behina?

$$
\text { (III, 11, 272). }
$$

1. W. S. Devia, opolt.. p. 74. 
The great ige of the selt-oellare at this time way be weon from the passage from Midaleton'a Xoux Mre Gallanta:

$$
0 \text {, my great bell-6alt! }
$$

Did jou not toe a fellow about apor with great liver ealt undor hil armp

Also in The Coragnb by Beamont and Metohex:

...........and the great paroel aalt.

$$
\text { (IV, 111, 86). }
$$

The term "pareel gilt" whioh sppears ceveral times In the plays, evidentiy algnifles that only part of the pleoe of plate wa gilt. From "part-g11t," "pareel-gilt" wat have been ovelred by ellipala. Other pleces of plate are reforred to as "paroel-811to" In shakespeare': II Henry IV, the hose reminde Falutaft: Thou did ewear to mo on a parepl-811t goblet.
(II, 1, 94).

At the ontertalnment giron to Blisabeth at Xenilworth, "the ohi ef table was cacmod with a 'salt, ship-rashion, wade of nother-or-pearl, garniahed with many design." Inother salt was fabioned of allver in the form of a wan in full sail. A allver St. George mounted and equippod wan alwe on the table; the horte' tell held a oaec of buives, while the breant of the dregon presented a siellar sooomodation for ogeter knives. 2

1. Beanmont and Flotohor, The Coxeomb, op.01t., p.86.

2. Six Walter Soott, Koniliorth. Philadelphia, no dato, p. 424. 
The table of the country gentleman was covered if th a oloth often apoken of as a orpet. Mapkins or torrels were need for iplng the hands after eating with the lingers, and in addition, baln and owor were pased to aid in oleanuing the bands at the beginning and ond of the meal.

oming to areat plonty of silver after the spanish conquests in Pore and lexioo, oupboards wore plontienily garnished with plate, Wth the additien of sone powter.1

In Remee and Jallet, the firet aervant orders;

$$
\begin{aligned}
& \text { piate. } \\
& \text { (I, T. IRE). }
\end{aligned}
$$

Chine dighes and plates wero beginning to bo neod. helped ont with pewter. I Venetian glase was a novelty prised by the upper olnased. Becanse of the oheapnese of alirox, "the gentility, as loathing the metaln, olirer and 801d. beoane of the plenty, ohose generally the Vonto glases," writes Harrieon." The poor people oonla arfort an inferior home-made glass of form and barned stono. In addition, poor foll atill need wooden dicheo or tronohera to a groat extent, but the well-te-do farmer and trader was expplementing bis wooden ware with perter. "Here was another extravaganoe whioh wade the ohamplont of

1. H. D. Fraill, op.01t.. P. 548.

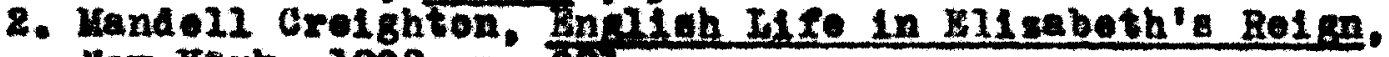
HeV Tert, 2898, p. 201.

z. WIIllam Harrioon, op.eft., p. 90.

4. Ib1d. p. 91. 
the Good Old IImee shake the1r heads; were not 'treenloarved wooden platter good onough for evaryody while Morrie Fngland was st1ul Lorrie Sngland 7 l the "treen" dishos ofton had proverbs oarved or painted around the edger, whioh served to Inetruot the cater. "Mor." eaya Puttenhan, in hie Art of Fnsulah Peede. "our anoestore were onretul to dolo out inetruction in many waye.........These aphorita we oall posier. and we de paint them now-s-dayea upon the beok side of oux frulte trenohers........... 2

George. the exrant, In the Honest Whore by Dokler, coments on the alagen et forth by the trenohere:

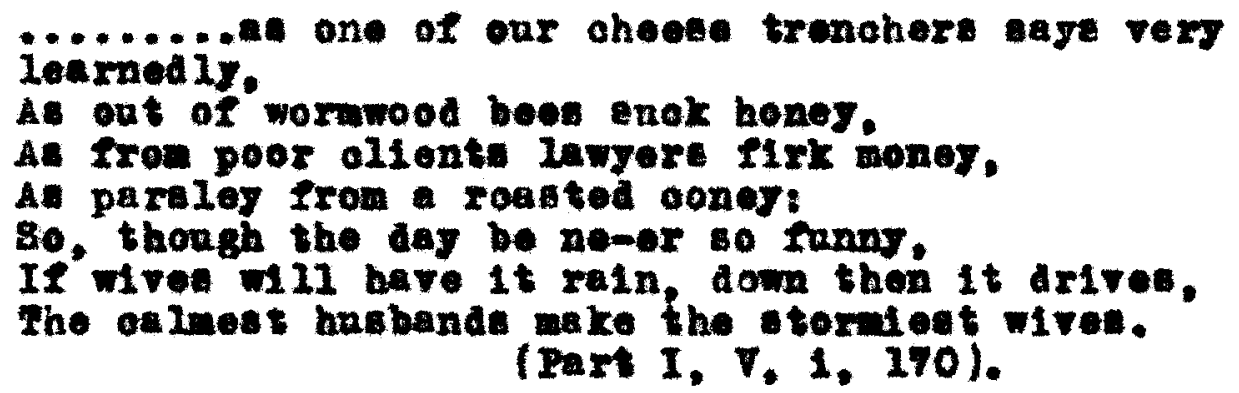

In Horthward Hoe by Webater, Doll remarik:

I'11 have jon make twelre posiea for doxen of oheese trenohere.

$$
\text { (III, 1, 216). }
$$

Philip Masuinger in The old in refere to this

onetom:

Seve Tew running admont tion

Upon oheeas trenohers...........

$$
\text { (II, 1, 489). }
$$

As hes been mentioned before, forke were in this 1. W. S. Darif, op.e1t.. p.40. 2. Philip Haseinger, opedit., The 01d Law, p. 489. 
period ooneidered an affeotation. It is wald that poen Blizaboth was the first royal personage in hingland know to have ownod fork and that she was seldon seen to use 1 t, eince the proferred to feed horself with hor I1ngera. In her posesest on were three forks, one of "golde, one of oerall. alightif garnished with golde, and one of orratal, garnished With golde elightiy, and epareka of garmotte." ${ }^{1}$ It wae not unt1l the midale of the 17th oentury that forks were ased oren by the higher olases, and aller fork wore not introduced un$\$ 11$ about $1814 .{ }^{2}$ As 1ate an 1700, people of the country distriote were eating neat with eingers. 8

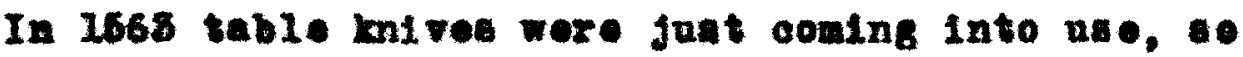
ordinarily the mife worn at the belt was preseed into aerviae

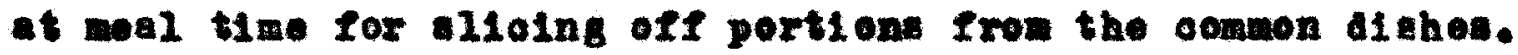
The Afpplng of knires into a common digh was not wthout its dangers if the following from Haseinger's The Qnnatural Combat be taken I1teraily:

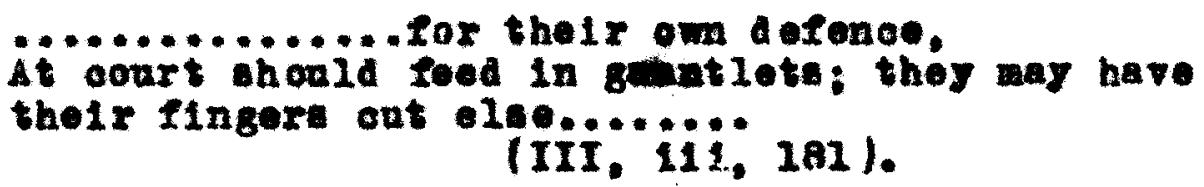

In Wostwan Hoe by Wobnter thore is a Ioference to drawing a knte to eat. Apomantas in Shakespearo' Timon of Athon apeaks of the carrging of knires to meds:

1. J. 0. Andrews, op.olt., p. 31.

2. J. Rolle, op.elt.. p. 55.

3. W. S. Davis, op.016.: p. 85.

4. John Wobster, Westrard Hoe, III, i1, 112. 
I wonder mon dere trast themeelved ol th mon:

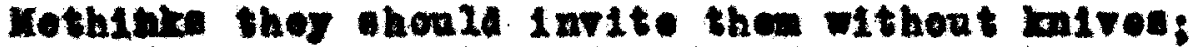
bood for their moet, and aper for thelr 11ves. (I. 11. p.924).

The Elizabethan period wat not wthout its attempte at proper table ot1quette. Perhag the ourrent objeation to eating with our knived it due to arvival of the rule that a knile that once had gone inte the individnal aenth conla not with propriety so baek into the comon dish. 1 The upper alasaes at this tiw rathor pridol themeelrea upon tholr table munere. W1Llian Earriven saya; "I wight bere taII comewhat of the groat milenoe that is ued at the tablea of the honozrable and wer sort generally orer the realm(albeit that too mob deserveth no oomendation, lor it belongeth to gueste nelther to be wati nor loquacel....... ${ }^{2}$ The ohllaren of the npper atratan were strietly adnont shed as regarde table mannors:

Hot maoking thy lipa as componit do boge, Hor gonating the bones, at it wore doge,

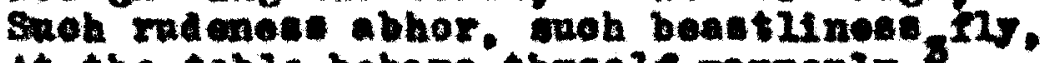
At the teble behave thraele annerif."

Jast how the lower olases condreted themselven at the table wil have to be loft to the imagimation. And porhap it 18 better so.

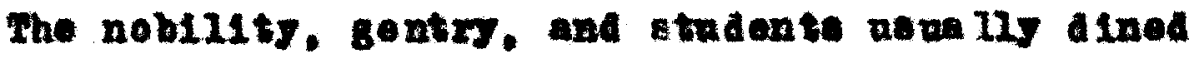
at aleven or trelve, and supped between fire and six. To

1. H. T. Stephenson, Bligabethen People, op.01t.. p. 385. 2. Villia Harrison, Op.elt., p. g.

8. Nm. J. Rolfe, op.018.. p. 62. 
take two moald only was the rele: none but the joung. the s1ak, and the rery eariy riser wal thought to noed an eariy moraing ropast. Iale Iondonorm holped out the day by balf-pint of wine before dinnor and a posest or night-eap before bod.

Soattered throughont the play of the period are nany referenoes to menl hours. In Heywood's The English Iravelzer, winsots, in apeaking of his olown say:

This rellow' wo best elook, He atill striken true to dinnor. Clow: And to apper too, sir: I know not how the day goes with rou, bet wy atomingh bath struak twelve.

I oan asare you that.

$$
\text { (I. 1. } 168)
$$

In Beaunont and Fletohor'a The roman Heter:

I ran: bat not do fast ae jour month will do on the atrobe of eleven.

$$
\text { (I. 11, } 16 \text { ). }
$$

The phyaioian in Ben Joneon's, the Caee in Altered. reoomenends:

Bat whon jour stomech serren, Dot at cleven and alx.

$$
\text { (II, 111, } 362 \text { ). }
$$

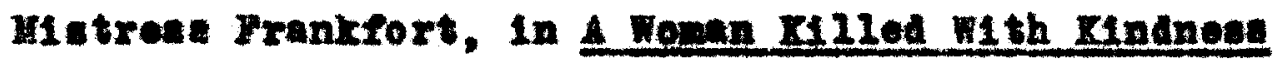
by John Heymood, Orderw her ervant:

......... TIE dx o'olook already truok. Go bid thes pread the oloth and oerve in enpper.

$$
\text { (IV, 111, } 47 \text { ). }
$$


In The Comedy of Errors, Dronte of Bphoune wa11s becarse alnner it inte:

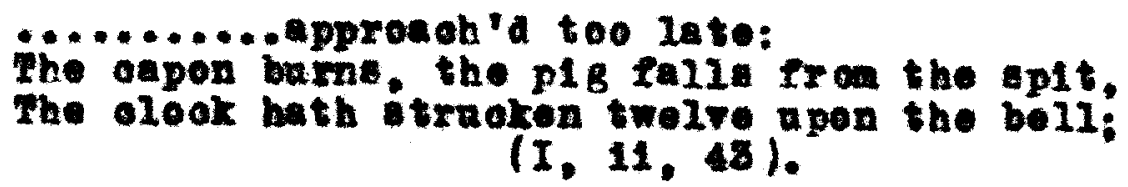

It weene to heve been ous tomary for the osok to otrike the dresser as a el gan for dinner. In Haseinger': The Unuatraral Combat:

When the draner, the oook' arran, thundere, Come on! (III, 1, 166):

In Jonson' A rale of 4 mb there appoars an expression, "Bad rang noon on jour pate." 1 This was a proverbial allasion to the oustom of otriking the dreaser at noon. 2

Ho opl tality was easy beoante of the abundanos of sorrante. The greet houses of the day awarwod with then, olnoe wages were vory oheap. A country gontlewan of wealth often had fifty aerrante. It is reoorded that when Bli zabeth dined at Blvethen, there were 200 footenen on aty.

In an age noted for feating, natarally the ooox was an important peraonege. He was the enpreme ruler of his dowatn - the Kitohon. As sald John Barle in his Microoomographie, 1688, "The kitehon 16 his hell, and he the

1. Jonspn, A Tale of A Tab, (II, 1, 156 ).

2. Ibla, note P. IF6.

8. G. B. Harrison, An Elizabethan Jouma1, Hew York, 1981, p. 59. 
Qevil in 1t......here be will donineer an rule the roast, In aplte of his aster, and onrtes is the rerg dialeot of his oalling." I Io lorded 1 orer the conlitond, threatenIng then with ahopplng lutros and with other wespon enoh as "a nous of hot broth and soalaing vater." 8

The heat of the kitohen alwaye gave hil a pexpetael thirst, onoh a thinet that "a histing pot of alo elaked hin I1xe water oest on a Arobrand, " In the Blogdr Brother or Mol1e by Bewwent and Pleteher, aone laid in the aervante" ball wow the thiraty cook oalling for cowe drink:

$\Delta$ hot day! a hot day! a vongenoe hot day, boy. dive me some drink: this Ilre's plegay fretterl Body of me. I an ary stilil chre me the jaok, bor. This woodon sktef holds nothing.

$$
\text { (II. 11, } 189 \text { ). }
$$

The sook of the Bli gabothan period hat been given

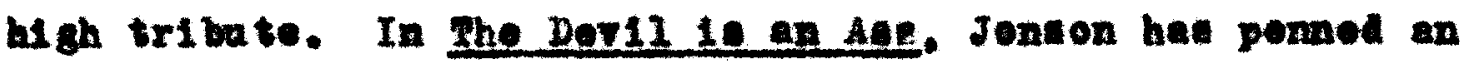
oxlogy to the angter cook - "the glory of the kitohen."
A water-cook! wh, he's the man of men, For a profesen! he designe, ho drewt. He painte, he cerpes, ho builas, ho fortifles, Hakes of tadelo of ourione fowl a nt llah. some be dry-dithes, owe notes round with broths; Hownte marrom-bonos, onts flety-angl ed onetards. Rears bulwark ples, and for hif onter works, He raisoth ramperte of imeortal orast; An teachoth ail the saotios, at one dinner: What ranis. What filen, to put his alshes in; The wele art allitary. Then he knows

1. John Dover Wileon, Ilfe in Shakedpeare's Bngland, Dambridge, 1920, p. 226 .

8. Ibit. p. 826 .

3. ISI, p. 266. 
The influenoe of the etare upon hit nente. And all their acens, tempers, qailities.

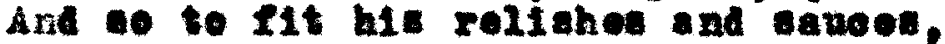

He has nature in a pot. 'bore al1 the ohymess. Or alry brethron of the Rosic-erose.

Ie Ia an arohiteet. an engineer.

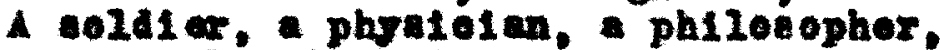

4 senoral mathomatialen.

$$
\text { IT. } 11 .
$$

Joln Rarie, In his Mere-oonerrephie. cont1mes hit portrat tore of the oodx:

He onning it not amali in aroht teoture, ror bo

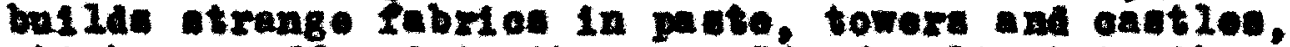
wheh aro offered te the abenis of ralient teeth.

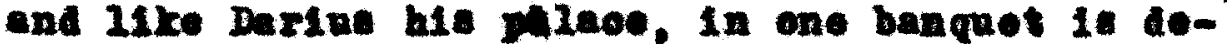
molidhed. Fe is a pilone marater of innooents.

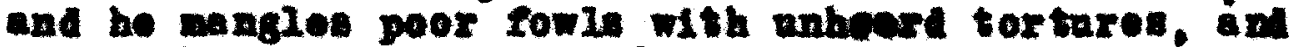

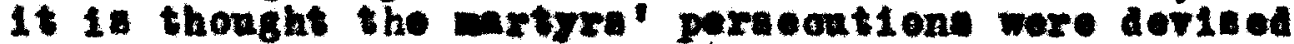

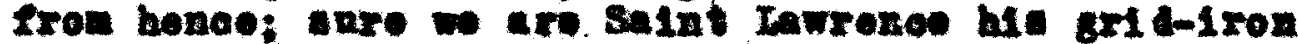

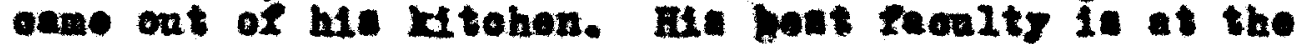

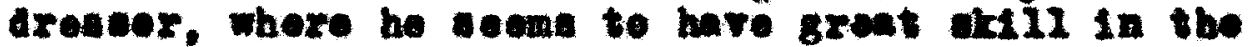

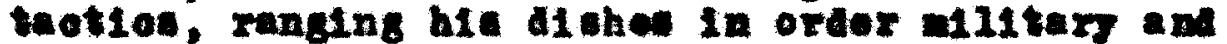
placing with great alsorotion in the loremeront noste nore trong and berty, and the nore oeld and oowardi In the rent. as qualing sarts and quivering onetares.

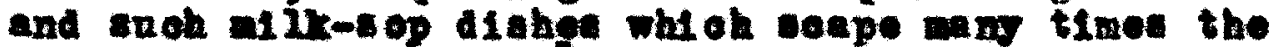
Inry of the enoonnter. 1

After a glanoe at the neme and roolpos of the pertos, one is inolined to think that no pratie of the

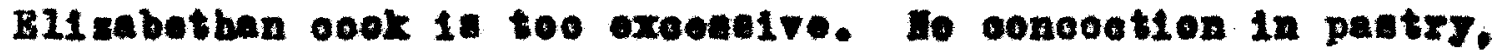
onstara or engez seon to have been berond bis power to oreate. no enlinary areole toe lanteatio lor hin to achiove. Saith the ood in Relle, ox The Bloel Rrother by Beannont and 10 toher:

If gox monla have the party epeak:

Tis in ay pomor. (II, 11, 252).

1. John D. W11sent on.018., p. 227. 
Frenoh Infinenoe was otill folt in the $x$ tehen.

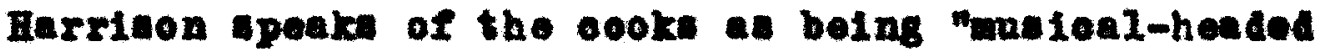
Frenohmen and etrangere." 1 The "lelokbawe" that are epoken of in the plays, oalled "pretty 21ttle tiag kiakehaw," by

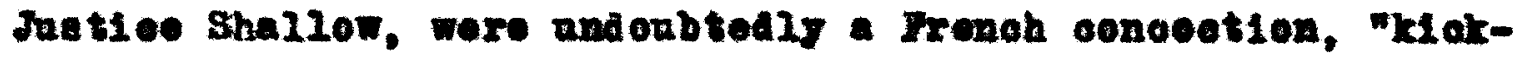
shaw" being a oorruption of quelque ohose. "i "Klokehawa"

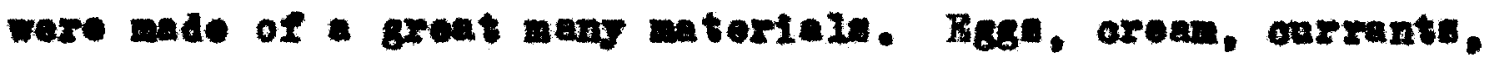

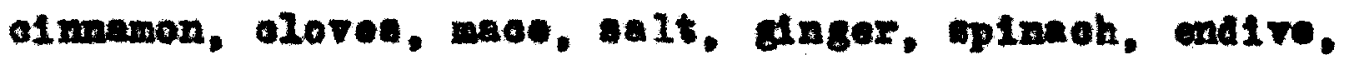
and warlgold Ilowern, to whioh aight be aded the further delleaey, "p188e's pettitoen," well bosled, wore all will Iried together with buttex.

In Thouns Dakker's the Belman of London, eppoars a deseription of kitohen aetivity that wat have been typieal of the arerage mantien-howe oulinary reglons before a feast. Dokrer witer that he went into the kitohen and saw thore:

.....mul otirring, an commonly is to be weene in a Booth, upon the flret day of the opening of a Fare. Sow ente trming of opite, and the place being a II omonky, de wee thinko on holl. For the jogate of wote lay as if the bad boon broyling in the infernall Are; the turme-apitif (who were poere tettered greati lellowed looking like se wang heo divele. Some were basting and secend like folndes powring coslding of upon the demed; othere vere arnotng of pro-meate, and thowed like hangmen oxtting ap of quartert. Wh11et enother wose eies glowed with the hate of the fire, atood pouking in at the ponth of an Oren, torurint conien as it ware in the truma of Iostifer. There wat suoh ohoppling of hoarben, wheh tobsing of ladele, such scolaing, woh langhing, woh wroarting, suoh ruming toe and fxo, an if plute had that day bidden 211 hil Iriondes to a reast, and that these had been the cooked that areat the ainner.

1. W1Illan Barrison, on.olt.. p. 88.

2. Y. W. Hackrood, bood Chere How York, 1911, p. 115.

8. Rose Brad1., op.01t.. p. 91.

4. Thome Dokker, the Boiman of Lond on, Londen, 1804 , pp. 78-79. 
In early daye the work of turning the apt fell to - sonIlion, nenalis a led, bat in the Tudor period, doge worv prosed inte certice in some houves. The dog wat tref nod to tum the spit by ranning around inalde onged revelviag whoel in the manner of a captive guirrel. If the dog lagged In his onthaniasm, hot ood was applied to hie hoole. In The Eitoh uf Bdmonten by Dorker. thore is this reforenes to a dog trming the epIt. Cuddy Benke in apoaking to the Dog saye:

Or if your stoma oh ald better like to serve in come hebleman's. knight's, or gentienan's kitohon. 11 gon aria brook the whel and turn the apit.... When they have roagt noat..... (7. 11. 466).

It 14 curiens to note that in the olden daye cookery wae coneldered as a brenob of modiolne; in faot the Iatin vorb gurere means to "drese a dinner," at woll as "to ouxe alsease." One of the very early ecok-book of Ingland, The Jorne of Curr. written in 1890, at the time of Riohard II, was complice munder the agant an avicuent of the masters of phrato an philoeoph that ewelled in the ring's oourt." 1

True to thit tredition, nost of the best old cookery booke in Ingliah were written by eainent docters. Dre roblan Vonner' Iia Reate ad Iitan Iengan. 1620; Dr. Theodaro

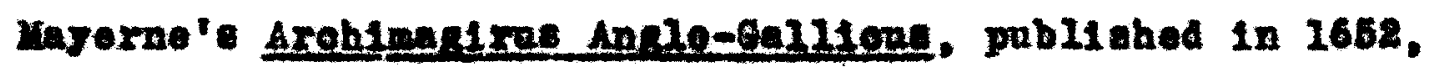
several yeare after the good dootor's death at the age of 1ghty-two years; and Dr. Konelme Dgby's The Clopet of the Buinently Learned Sir Yoneloe Dipbre It., Opened, writton in 
the early daye of the 17th contury, all gare medioal and

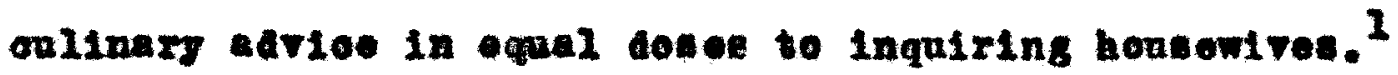

In Dr. Willian KIng'a the Art of Coekery, whioh was written in Imitation of Horace's Art of Pootr. comotim in the I7th oentury, referenoe is still wade to this relation botween dootor and oook.

....the Cook mat pase thro" all degrees, And by his Art dieooriant Tempere pleage, And miniater to foe ith and to Di sease.

Those modieal-oookery mamals partionlarls opesialized in reolpes for the preparmtion of home-nade medioines. The gardene of the mansione furnished a hage expply of herbe for the boweopathlo brew and ot her oonooetione that wore rell 1 owely taken for all worts of malad of ranging frow the plague to "Inward braices."

Of "II the "berbe" that wore found in Bllubethan gerdene, lettroe and onlons seat to hare been the most ueful. Aovording to John Gorard's Ferball or General Historte of

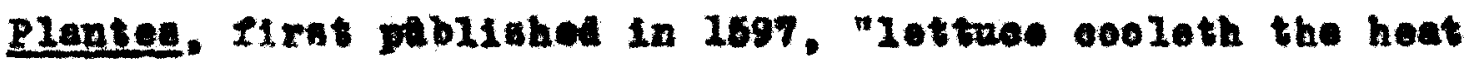
of the stomedre, orlled the hoart-burning; and holpeth 1 t when 1t is tropbled with choler: it quenoheth thiret, and

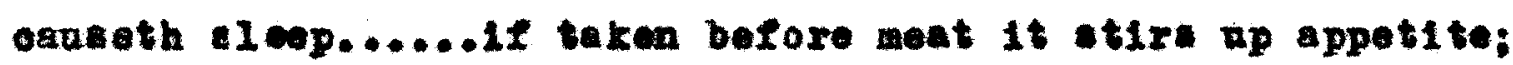
and if eaten after euppor it keopeth oway arunkonneses whioh oomeneth by the wine; and that is by reason that it otaleth

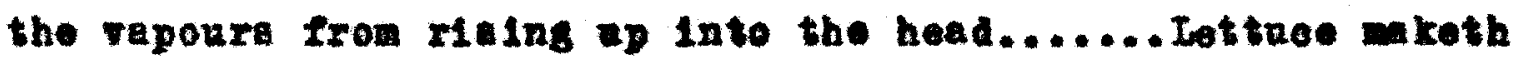

1. 1. W. Hackwood, Op.eit.. p. 286.

8. Dr. Whiliam Iing, the Art of Cookery, London, 1709, p. 65. 
- ploagent saliad, bolng caten raw....but if it be bolled 14 10 wooner digeated, and nourisheth nore." 1

Phystolane in Rlistbothen Ingland socad to have ueed poultioes of lettuos as cooling appllostone, as is orineed by referoncer to "lettien eape" in several of the plare. In Thierry and Theodoret by Boannont and Plotchor, is such an allasion:

...phyaloisma.... Thth lottioe capa

An Bnglish dootor with a banoh of pot herba.... (7. 11, 568 ).

In Jonglear thorae by Beaument and lotoher, tho phyal elanf or probably barber forders:

$$
\begin{aligned}
& \text { Bring in the lettioe oap. You maft be haved, } \\
& \text { afx. }
\end{aligned}
$$

Antonia, of Bearnont and Netoher' The Chanoes, has been wounded and bolng treated by dootorw, complains of

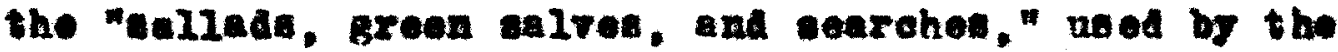
phrelotena. 8

Oalons ware oredited wth many valnable properties. Gerard anerte that:

The folos of Oni on amaffed up late the nose, pargoth the head, and drawoth forth raw 21 ganatlab hnmorn. Stauped with Salt. Rue, and Honey, and se applied, thes are geod againot the biting of a mad Dog. Rosted in the embers and applied, they ripom and breaks ould Apostrues, BLIes, and on oh IIre.

The julee of ontenn wixed with the decootion of Penni-royall, and anolnted upen the gontle menber with a festhar, or a olonth wet therein, and applied

1. John Gerard, Joares fron Gerard's Berball, Bost on and Mow Tork, 1951, P. 19.

2. Beaumont and Fiotoher, Mong1ear Phomen, note p. 468. 
casoth the wame vory moh. The guleo anolnted npon a plid or bald bead in the Sun, bringeth the halre aga in rexp apeodily.

The jaioe taketh away the heat of goalding of th weter or 011., as eleo burning with fire and gin-ponder..

Onient iloed and dipped in the friee of sorrel, and given nnte the sloke of a tertian Agre, to eat, take away the 1 t.

The 0niok, being eaten, yea though it be bolled, cancoth heal-abhe, hurteth the ogea, and waketh a wa dim-aightod, dulleth the seneen, and prproketh overwoh sleop. expeelally beling eaten raf. 1

Ifkewias in Dekrer's the Cule Hormbook-How a Galint 18 to Behare Hivell Parsing throngh the C1ty: "If ron anell a wah, and thet jon wa casily do, for oommonly they eat onione to keep then in aleoplas, which tho sooonnt modi of againat $0014 \ldots \ldots n^{2}$

Benmont and Flotohor in the Menan's Prise afrise that:

You wy eat ontons. They parge the blood. (IV, 1, 384 ).

Anong othor valuable herba mentionod are oherrill, "good for old people that are and and withodt courage: $"$ " gorrell, "nted in green sance and for then that bete soke

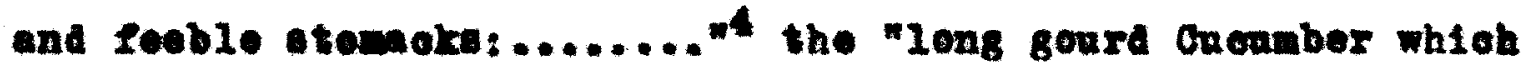
bolng late in the oradle of the jong infant whilat it is

1. John Gorard, opedt., pp. 177-178.

2. Thoma Dokter, the Gile Hornbook op.ait.. p. 66.

8. John Gerard, op.er.. p. 160.

4. Ibla, p. 42 . 
aeleop and siok of an agne, it ahall be very quiokly made wholo: ${ }^{-2}$ and the leavee of the Bramble (or raspberm baht whioh boylod in water makes a deoootion that fastnoth the teeth." 2 There were other herbe in whe to Noboereth the hearte," to "keope 11 ttle coga from growing groate," to onre "over-mob sighing," and to oure woh al be Molenoholike, cad, pensive, and withent apeoh." 8 ono oonld oontime to liat Indofind tely the farolnating virtuce of these garden

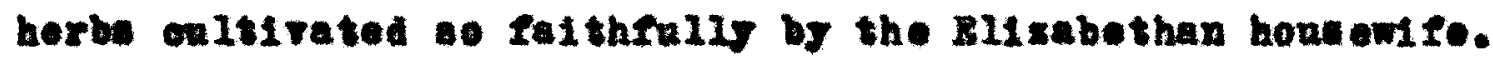
Whether these home-wrought rewedies were effichelons or not, areat deal of falth went into their maling.

Howe ontertalnment was more a part of conntry thas of of ty living. In the towna, partionlarly Iond on, the lnae, teverna, and ordinarlen were the oenters of coolal life, es were the coffee houses of a later date. Wililan Harrison in oomparing the differenoes in country and eity hospltallty writ toe:

In the coantry if the zriende ales of the wealthier cert cone to thelr housed from fax, they are ogmonly so weloome t111 they epprt as upon the elrat dey of

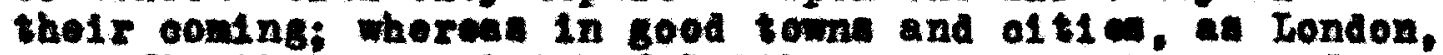
non oftentimes oemplata of Iittio room. and. In rowara of a lat oapon or plents of beer and watton largety bentowed upon the in the conntrs. a oup of wine ox beer

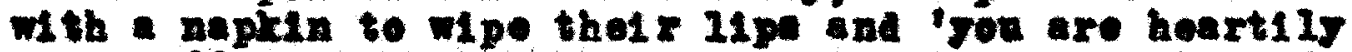
welcon!" in thonght to be a great ontertelments and therefore the old conntry olerte have Imabd this saying in that bobult upon the catertainemt of tomenen and Jondonere after the fay of thelr abode. In this wanner:

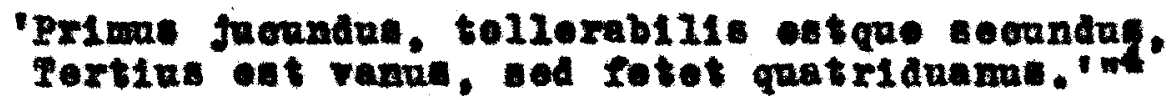

1. Jobn Gerard, op.oit., p. 184.

2. Ibld, p. 261.

3. Ibed P. 168.

4. TIII a Harriton, op.alt., pp. 95-96. 
In contrasting oontry plenty with ofty stinting,

Ford in The Witoh of Ramonten sare:

Should I diet three degt at one of the glender al th-sepport, ron alght and mo to Barber-

Bargeons hail the fourth day, to hang ap for an ana tom (axeleton).

$$
\text { (I. 11. } 187) \text {. }
$$

The ofty dinnere and oorporatien featte were an exeeption, for these wore ocoastong of sumptuoue aplondor attended with a great oonsumption of food and arfint. Harrison rewarks that the feasting of the oompanten of erexy trade on thelr quarter dagn are "nothing inferior to tho

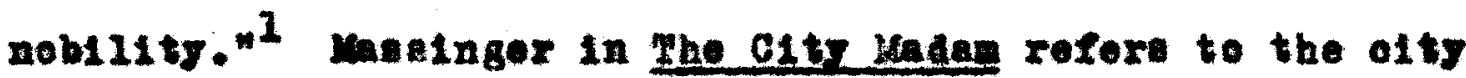
Ieasta:

Yon may tall of oountry-ohristraasea and oourt ginttony.

The1r thirty-pond buttered esge. their ptes of carp tongues,

Their phoasente arenohed wh thebergria, the caroasea

Of three lat wether: brained for grav.

To make tavoe for e ingle peacook; jot their roaste

Were rasta, compared with the ofty's.

Iradewa11; What dear dainty

Was 1t. thon minur'et at?

There were three moking plge gerved up in a diah,

so'on from the oow as coon an farrowed.

A fortnight led with dates, and mo baino, That stood as mater in twenty rack plooe, And besldes the pudding in thelr bellies, bade

Of I know what. - I dare swear the cook thet areased it.

Was the dovil, disguleed as a Datobnes.

$$
\text { (II, 1, 421). }
$$

1. Willan Harriaon, op.o1te. p. 94. 
Also in The Mn1d of Hononx by Haseinger, the laviahnose of the ofty seaste is olted:

The ofty ontertainment! A huge shonlder Of Bloriou lat ram-mattion, woonded With a palf of tame ante or conies, a orab-tart, With worthy 101n of vea1, an valiant capon.... (III, 1, 848-4).

Phe ordinarion and taverns wore the olnbs of the period, and here Iondeners, malenine for the mogt part, congregated to moet thelr fellows and dicons the nowe of the day. In Haseinger'a the citr yaden, this funotion of the ordinary is cet forth by Iake:

Then eltting at the table with The graverios of the kingdom, jou shall hear Docurrente from all corners of the world. Of plote. the connsele, the designe of prinoes. And ereely oeneure thos; the of ty $x$ te cried up. or deeried, thetr passions lend thom. (II. 1, 424).

In Thome Dekrer'a Plogue Papphlete is thown a gathering of Londoners at an ordinary "where the Patte Hoat telles Tales at the apper ende of the rable."I It was the hablt of all the wea abont town to dine at tho oxdinary at the table of the hoat, term now oonverted to "tsble 'hote." 2

Innwerabl are the allust one to the rell-known taverne and ordinarien of the day. In Iowed from Bartholomom Fayre, eathor unknown, nom of the moat famone eating and drinking places are wentionod;

1. Thome Dekker, The Plegue Pamphlete, Oxford, 1925, p. 1. 2. Frederlok Hackwood, Op.0it., p. 138. 
There hath beene a great eale an ntteranee of wine, Besidea beere and ale, and ipeoras tine. In every oovitry, region, and nation, Chofely at Bllingagate, the salutation, And Dore's Head, neore London Stons: The swan at Dewgate, a taverne well rnowne; The Hter in Choepe; and then the Bull Head, And many like place that make noses rel:

The Bore'a Head in Old Mish Street, Phree Grenea in the Vintree.

And, now of Inte; St. Mart in's in the Sentres;

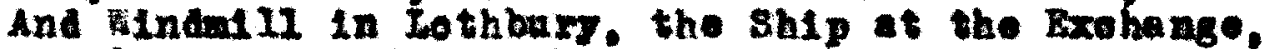
XIng's Hoad in Fow Min Streote, where rojeter. do range:

The Mextali in Cornhill, Red IIon in the Strand. Throe Tring, Hogente Harket, Old Mibh street it

One of the most famer. of the saverne wat Danaten's, which later beoane the Derll Pavern, whese 18 wa the deril peeping over the ahoulder of St. Banstan. Here wa the fenoug club over whiob Ben Josson preeided a porpoteal ohalrean, ad at whioh shakeepeare, Bearanont, Fletohor, Rorriak end other 11terary 11ghts of the any ascieted. The Apolle room of the tarern was the pormanent meting place and it was berred to all but nobbers. Over the ohimnoy, ongraved in marble and Bo2d, wero the "Convivial lawe for the Tevern Aoademy," Irawn up in Ben' most elegant Latin:

A the fund of our plesture, lot onoh pay his shot, Bxoept wome chano eriend, whon member bringe in, For henoe be the ead, the lewd fop, and the oot; ror such bave the plagues of goof oompeny been.

Iret the learned and wity, the jovial and gay, The generons and honest, oompose our froe etate; And the nore to exalt our delight whilet we atay. Iot none be debarr'd Irom his oholoe female to.

1. Banment and Fletcher, Mits without Moner, noto p. 48 . 
Let no eont ofrenatre the ohawber infeat. let raney, nor coet prepare all our alsher.

Iut the esteror and the taste of caoh guest,

And the cook, in his areseing comply with their wiehes.

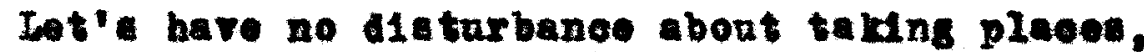
to show jonf nio breeding, or ont of rals prial. Let the arawer be reads ith wine and freah glaeses. Lot she waitere have eges. though their tongnes wast bo ty.

Lot our wines without atxtare of atum, be all ine, Or oal 1 ap the mantex, and breat his anll noodie. Lot no nober bigot here thint it a in. To pab on the ohirping and nodernte botsio.

Tet the couters be rather of book than of wine. Iet the ocmpeny be nelther nolisy not mate. It none of thinge wertona. nuoh less of atvine.

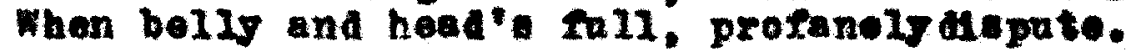

Lot no anoy ialor presume to intruat.

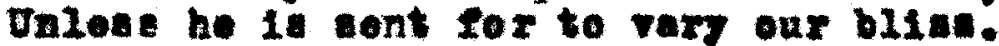
ith atrth, wi, ana aeneing, and ingtng conolnae. To regale orexy some, with alight in oxoent.

Iet ra111exy be whont andee or heat. Da11 been to rese let nene privilege take. Fot no pootaster command or intreat Chother oxtengere verwes to vare.

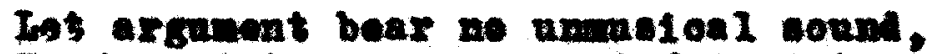

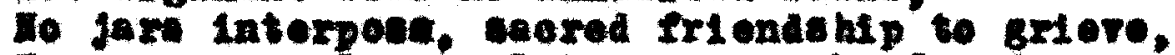
For generons lovere let a corner be conal, Whare they in act alghe mey thet penelong rellere.

Hke the eld Iapithiten. Wh the goblete to tight. our ow "monget ofronoen nnpardon'a w11 rank. or breaking of windowe, or glases, for aptght. ind apoliting the good for a rakohelly prant.

Whoeror chall publiah what' sala, or what's come. Be he banish for erer on aseobly divtne. Lot the Ireadon we take be perroted by nome. To wate any gailsy by arinking good wine. 1

The Mermala Tavern, Likewie a popar meting plaoe ef the poets, 18 often referred to in the ilterature of the 1. Ben Jongon, Works, London, 1816, Pp. 85-86. 
der. Franois Beaumont in his totter to Ben Jonson speake of 1t:

$$
\text { I 110 and drean of jonr full Hexnale wine. } 1
$$

The 萑itre was nother tavern w1doly patronised by writere. Evidently it wae known for good lood, for in A yad Worla Ur vanter, an exoellent moal in oalled "a right Hitro sapper." 2

Taverno were ldentifled by bush. In The yald's Iraged by Beanwont an Iletoher oocur reforenoe to thic oretom:

Cood wine requirea no boh, ther asy.

$$
\text { (Prologoe, p. } 61 \text { ). }
$$

Denuld Inpton in his Ionden and the Conntrer garbonedoed, 1632, writor:

If these houses (alo-housen) have a box-busb, or an old post. It is onongh to ehow thatr profestion. But if they be graced with a len oomplete, it' a of en of a bood ore tom."

The tarern could alto be Identified by a green or

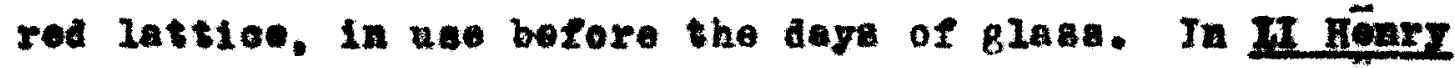
II by Shakespeare, Falateff's page ears:

$$
\begin{aligned}
& \text { 4 00210 we 'on now, my lort, threagh rod } \\
& \text { latt10e, and I could disoeta no part of his } \\
& \text { tace from the window; at } 100 \mathrm{t} \text { I epled his oyes..... } \\
& \text { III, i1, 84) }
\end{aligned}
$$

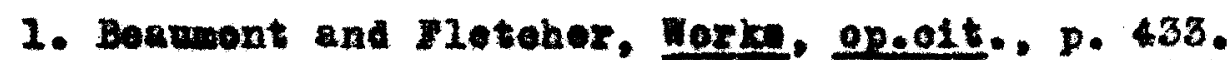

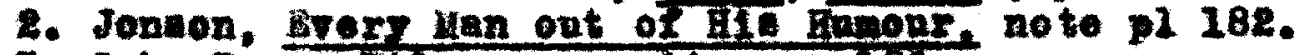

8. John Dover Wilion, apeat., p. 106. 
Bridently this Iattioe was uned to afford the arinkere Whin the taverin sone privacy.

gereme vere hanuted by itinerant maloiana, very appropriately referred to as "one notae of fladex or othce."

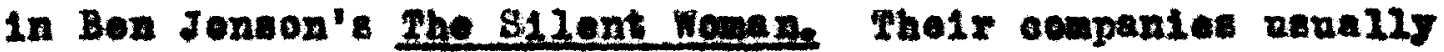
connleted of three an tool thelr nemes fro the leader of

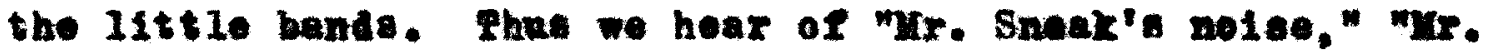

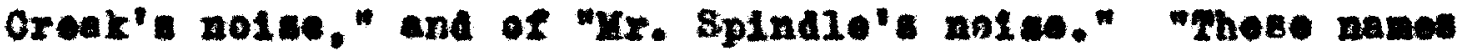
were probably the tarention of shareapeare and other writer. bat they prove the extetone of the enstem.

It wa the fachion of the period to 8170 names $t e$ partioulax rooms in the tarems. "The cnstem provalied at

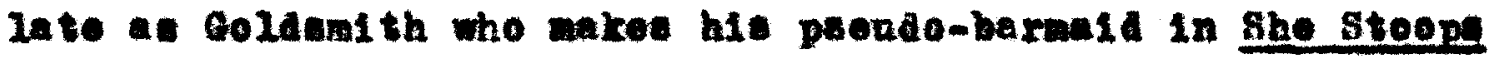

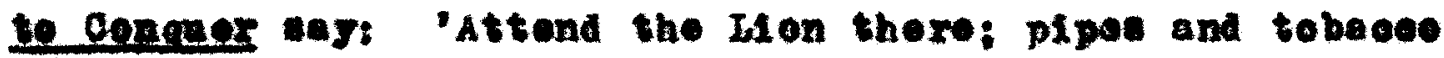

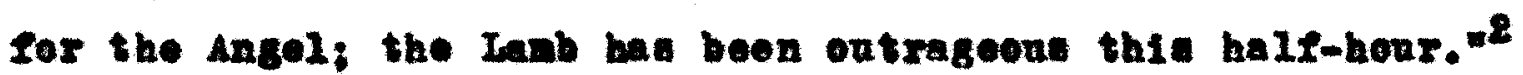
In The Ceptain by Beanont and Lleteher, the tarera boy is oratered to:

Take a gallon of saok, and pint of alive to tho Unieorn.

Took Into the Hab's-hoad there. Boore grart of alaret to the Bar: And a ponnd of aranger into the Power-pot. and teteh tobaces ror the poucoak. (IV. 11, 821).

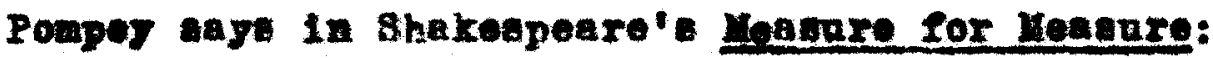

turse in the Bunoh of Grapes. Whare Indeed jon bave a delight to 81 b. have rou nots (II. 1. 88 ).

1. Ben Jenson, Epleoene, or The S1lent Tionan. op.o1t., p.402.

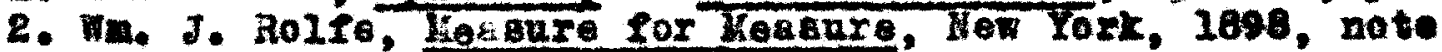
24. 
Thome Dekker in Ahe Gule Hornbook gives advioe on

"How a Gallant ahould boharo himele in an Ordinary." Ho

Instruote:

In Inventorie of the Kitohen ahould be oalled for, for 1 wore most tajior-like, and to be suepeoted you were in loague with nome Kitohen-wenoh, to dewoend youx selfe, to offend your stomoh with the sight of the Iarder, and happliy to grease your hoooustrenents. Haring therefox recelved this bill, you shall bave man sallade tand on your table, a it were for blankes to the othor more cervieable as shest and aooording to the the of year, vary your fare, as Capon 18 a - tirring neate a omotime, oraters are a bwelling meate conatimes. Tront tiekilng monte cometines, greone Goose, ná Woodoook, a gellante meste nonetimes, eapeosaly in a parerne." I

\section{Advioe is I1kendse given the young gallant as to}

his oholoe of 11quor:

Let not your Phraitian oonfine you to ony one perticular 11 peor: for as it is requidite that a Gentloman ehould not a lnates be plodaing in one Art, bat rather bee a general sohollor. (that if. to have a lioke et all sorte of learning, and away) so 'tis not fltting an ahould tromble his head with sooking at one Grape. but that be may be able (now thore is generall posel) to drink am stranger drunke in his own element of dxinke, ox more properif in hie om Ianguage."

It was ane tom st this time to send prosente of wine Irom one room of the tavern to another. In the Uerry Elzes of rinceor. Bardolph informs Talataff:

There's one Master Brook below wald fain Speak of th you: and hath seat your worehlp A norning's dreght of anok.

$$
\text { (II, 11, 62). }
$$

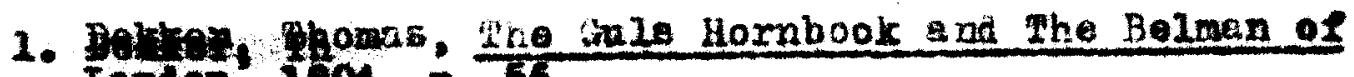
Iendon, ICo4, p. 56 .

2. I0I. . 57 . 
There were two oxpreesions in oomen neage whtoh referred to hospltality. "Jaak Dram's ontertainment wab a phrase algnifring 112 treatwont or turtalng an unweloone guest ou t-ax-doors. In the wibe Wemen of Hosedon by Dekker. Soneer Inquires:

And, Taber, are you appointed to give al Jack Dran's entertalnment? (II, 11, 275).

The other expression, "Aining with Dake Rumphrey." mesnt not to alne at all. In The Rape of laorooe by Ferwood:

The beggar to the Brah, then meet And with Bir Humphey aine.

$$
\text { (II, }, 365 \text { ). }
$$

a Tary good pleture of the 1dlex' il fo In London is sketohad in Davies's Engrame:

Mret, he doth Moe te ten: and at eleven He goes to Grin', where be doth ont t111 one: Then sees a play t111 aix, and aps at ceren: And after anppor atralght to bed is gone: And there tili next day he doth remein. And then he linen, and sees a conedy. And then he eupe, and goes to bed egin: the round he rans withont variaty. il

The court of peen w11 zabeth was charaotertzed by formal and alaborate oeremony. Her love of intrioate form is well 11lastrated in an gooount by a Geman travaller. paul Hontzner, of the kerving of the geen'a dinner:

1. H. D. Tra111, ofolt., D. 780. 
A sentloman entered the roon bearing rod, and elong with his another who had a table oloth, whioh after thoy had both knoled three tives, with the ntmost veneratlon, he upreal, npon the table, and arter

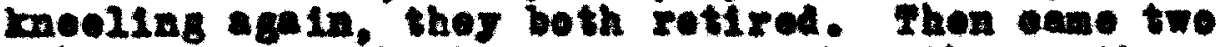
othere. one wit the red again, the othor with a valtoe11ar, a plete and breal; whon thor had moeled. as the othere had con, and plaeed what was bronght upon the toble, thog top rotired, with the seme oeromonich pertored by the tixte

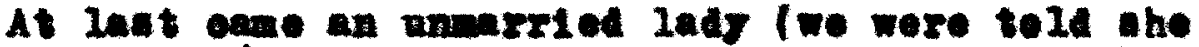
wes a contese I and alons wth her a arrted one, boarIng asting inite: the former vad aroneed in white e11r. Whe, whon she ha prostrated berwelf three tines

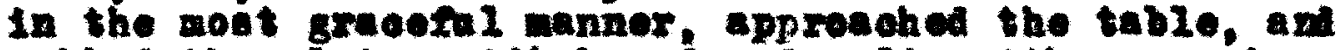
rubbed the pietes with bread and salt, with an moh oare

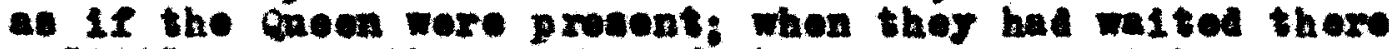

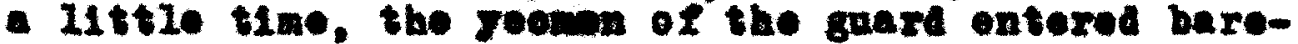
headed elosthed in boarlet with a gelaen rone upon their back. bringlns in at oach tnen oover of lour and twenty atshes, aemed in plate, most of it cilt: these Lisher were reesived by gontiman in the wane order they were brought, and placed apon the table, whil th

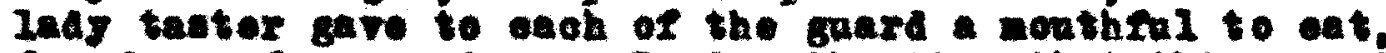

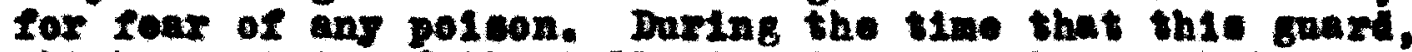
which conniets of the tellect and stentert non that on

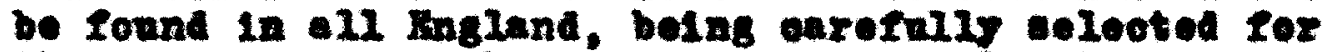

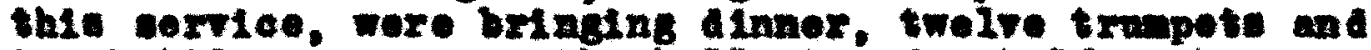

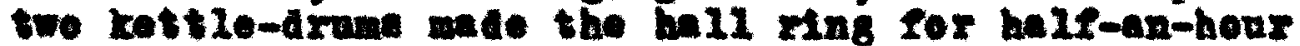
tegether. At the and of thic expmealal, a mober of

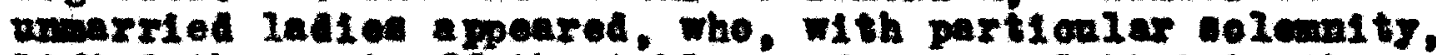
I1 Ited the meat oxf the table, and cenvered it ints the Qmeen's Imner and noxe private ohamber. Whore after she

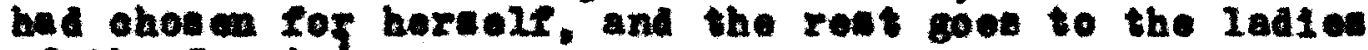
of the court. 2

It is interesting to ronomex in roaking this

tedione oeronony of the cerving of the Quen's dinner, that

ahe na not area within sight of ald the ritual.

The regal banquete of Blienbeth al fered from thone

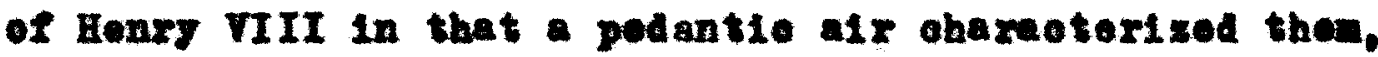

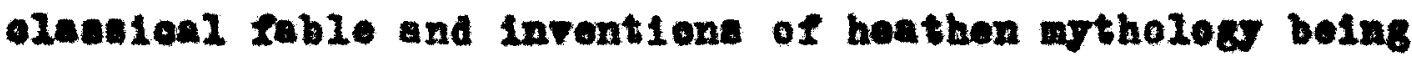

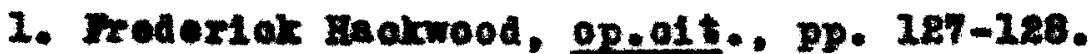
A1ne. Inry I. Oartis. Gasland of Sons and Stoz, Hew Tork. 1981. DP. $\operatorname{ses}-205$. 


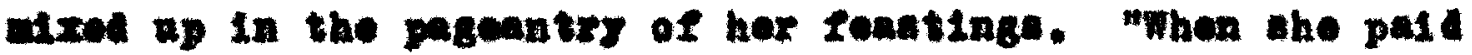

- vitt to the hane of one of her nobles, as the onterins

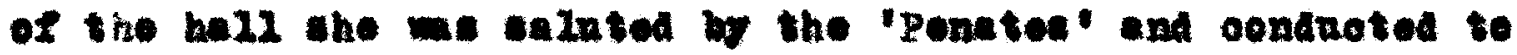
hor pritr ohamber by Merour."

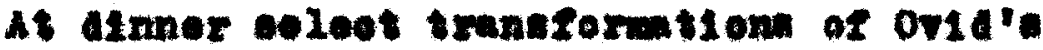

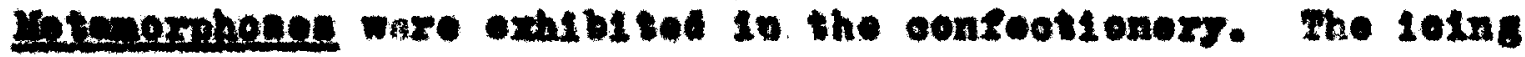

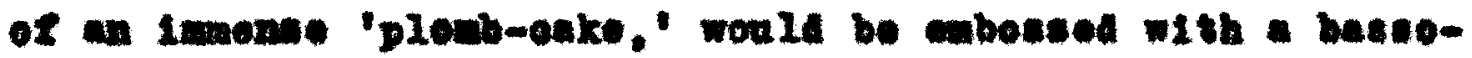

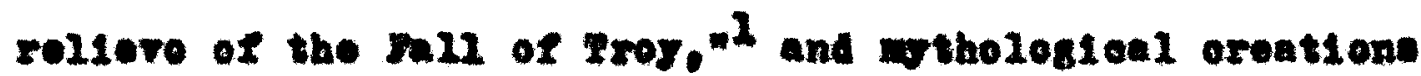

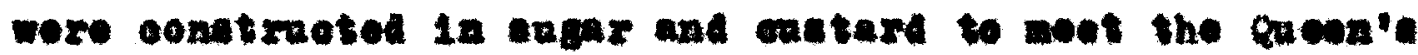
pleasne.

Wohelle reooren thas he wa prosent at a banet.

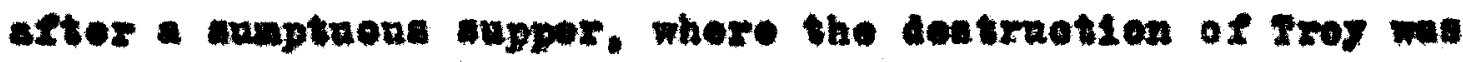

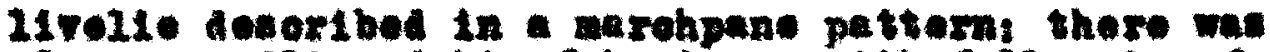

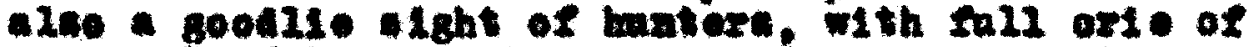

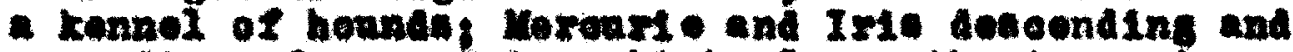

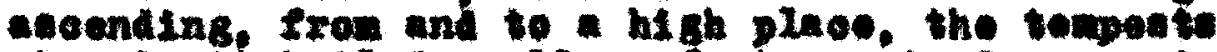

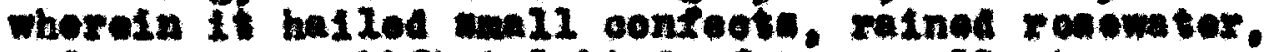

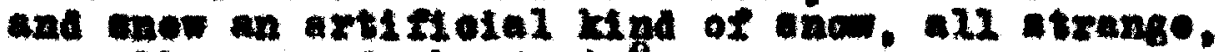
mervelieun. and abmant. 2

This extravaganes was atirised by Benneont and

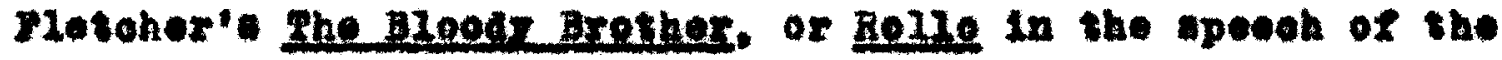
ands:

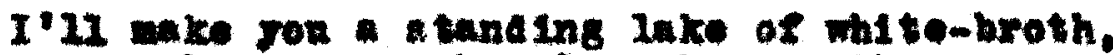

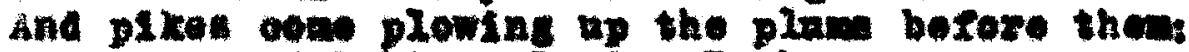
Arton on alphin, pinging Tabhryaes And a breve wing horring with his otx una onion

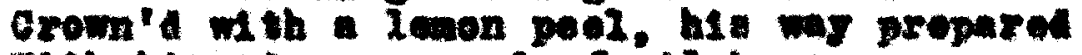
with his crons guara of pilchers.

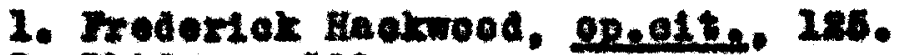
8. Int. 2. 199. 
I'II bxing you in the Ialy-110n-0'-real, Ith the long lore the bore the Prinee of orange: A tull vine bending ilre an aroh, and under, The blown god Beoshn, eltsing on a hogohead. Hia eltar hexe; before that, alnop vintnor Kneeling, and offering ineenge to his desty, Whioh abell be only this, rod eprate and pilohers. (1I. 11, 151). 
GHAPAYR II.

MOOD OP THE ACE OP BLT GABBER 


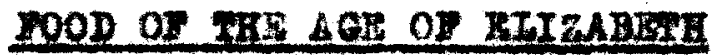

In the day of caeon Hlisaboth all wore "aquare catera" of solid rood and "Iarge tabling and bell cheor" were oonsldered by forelgnert as provalling linglish chazaoterietion." VILLem Harricon, howerer, notes a great inprovenent in orer-eating and aranomean, and pock of the "moderate eating and arinking that 10 caily soen." 8 Which to a twent1eth-eontary reader seom a comparative Btatement indead

Brealeasta were not eaten gonerally seve by those who axose early. The anjority of people wore content ath a Iittle bread and butter washed down with pot of ale. there are ond a fom referenoos to breakfate in the playe of this time. Hyre, the shoenaker in Dokker's the Sheemerex'e Hollax, Iovaly oomplains:

Io't seven a olook, and won's broakfast not ready? (II, 211, 70 ).

In Oreen's Zriar Bacon end ylar Bunger. Iney in-

1. Boanont and Hotoher, op.01t., Benduos, (II, 111, 60). 2. H. D. Yra1 12, oplets.. p. B85. 8. W11liam Harricon, Decti., p. 59. 
gatren of the keeper:

What bare you eit for breakfast?

$$
(7.1,296) \text {. }
$$

Oircumbanoed in both inctances seen to revenl that thoee demanding breakfunt had rigen at an early how. OrdLnarily a moming aranght was oonslderod onfriolent to bridge the gap put12 dinner.

In Ianaingor' ghe ereas Mare of plorenes.

Petrucoble, vervant to the dake, says:

Iot ne take thes

onr morning druaght. Buoh an eat atore of beef. llutton, and cepons, wy proserve thatr hoalthe W Ith that thin oompontion oalled enall beer, A., the cald, the do in lingland...... (II, 11. 288 ).

It is recorded, howerer, that Qneen Elisabeth ald eat breakfant and that ber worning moal rewalls coulsted of "rine wheaten loaved and eakes, ale, beer and mine, pottage mode with matsen or beer, ohines of beef (probably oola). rabuts and bntter. In ono of hor progreanod through the country, three oxen and one hndred and forty geene

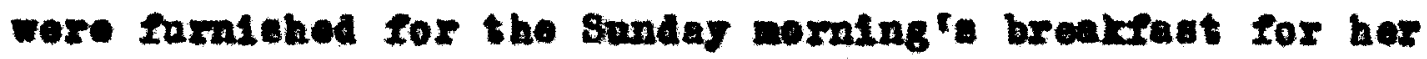
retimue." It mention is made of the feot, but perhapd Bilgabeth and hor oourtiera had riaen early too.

Dinner for the upper elasees wan the large menl of the day. It genoxally consteted of three oonrees: I1rat eeat; the ceoond, gano; the third, aweets. The last ocoree,

1. J. D. Andrews, op.01t., p. 5. 2. Aloo W. 8. Davin, Op.olit., p. 68. 
ealled the bangret, was orten corrod in an arbour or abmerhouse, from whioh, after sine epent in oonvermation, the fandly adjonmed until the onppor hour.

The IIrat aonxes of an eleborate Alnner uanally bogan wi th a warkhaling of the sallete in tholr propor ortar:

The grand wallet, the grem mallote, the boliod

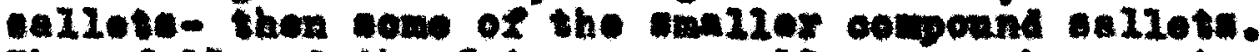
Then followed the Iriearuen, oollops, rashors, ote. The bollod went which cene next in orter are to be aooempanted by the brothe, woth gimple and atemed. The aimpler kind wan in feot the water in whiob the joins or jolnte had been bolled with a hander of horbe acted, while rioher waterial of noat, onlree' head or Ilih would be inoluded in the otewi broth. A11 corte of roals moath would next be placed on the table. bagluning with the ineritable ohine of boes. or a eirlein ani las or mutton, leading on to real, - pis. ox capena. e goene ana a man.

Roos on the table wat be found for the hot

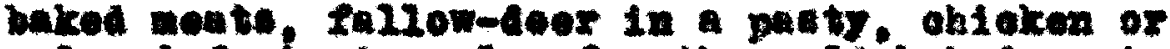

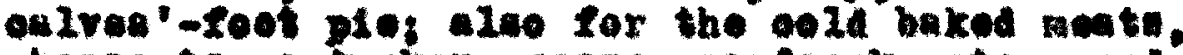
phoanants, a turker, goome, wodeook, ote. and the

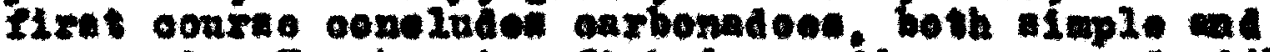

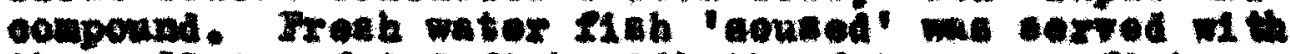

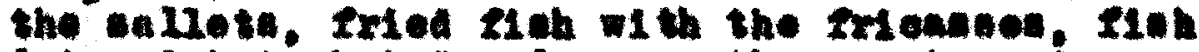
'etewed hot. but ary.' among the roat meati. wea

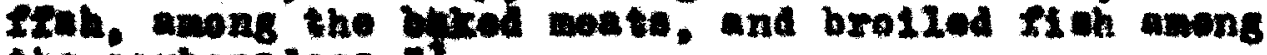
the carbondaoes." 1

The ocoond conzwe, another more than amply satis-

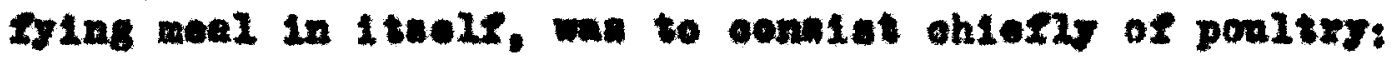

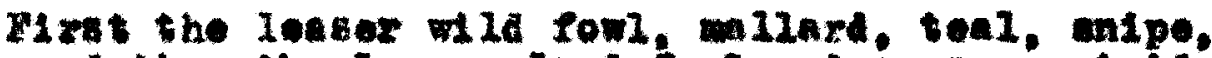

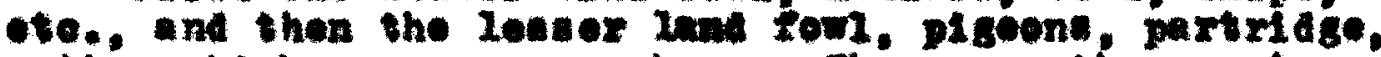
raite, ohloken, young pen-hent. Then onne the great

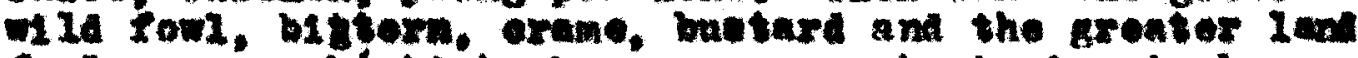
lowls, pecaeok (whloh, howerer, were beginning to be regardod as acooration than a diseagy), phontanta and gulls. The eoeond anarwe olosed with hot baked pion

2. Roce Bradieg, opedt.. D. 72. 
Ind tarts of marron bone, quinoe and other lusoloue meterial, and oold wirat pion of red-deor, hare, gamen of bacon, roe and mill botr, ete. "I

The thire conxte ox banguet nunally conafat of of

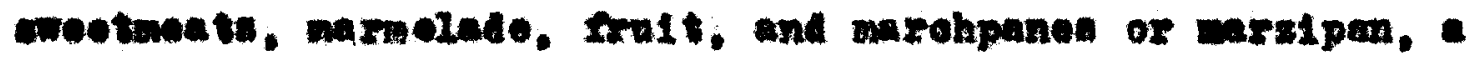
mxtare of augax, ground almonda, and a Ittle nour, flavored wth reapinter.

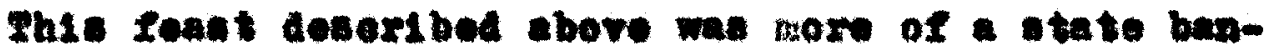
geot. For an oralmary alnner anitable for a "ramily not to

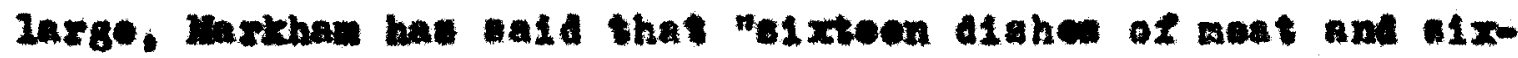
teen at shen of anlad and regetebles, wonld, if properly

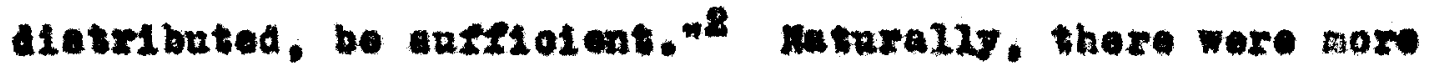

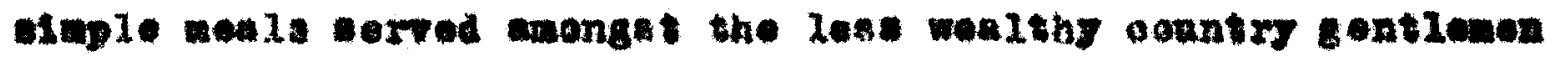
and merehmnes. Harrieon wrote;

In nuber of aidhos and ohanges of teat the nobl11ty of ungland do wost exveod. Ho day pantes but

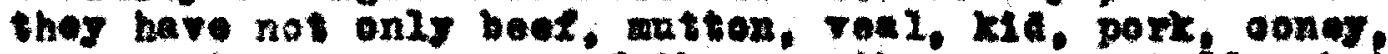

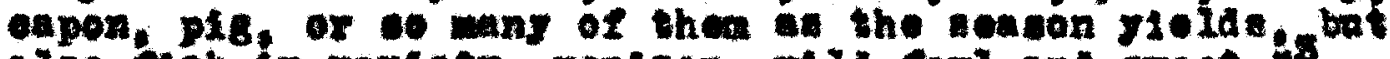

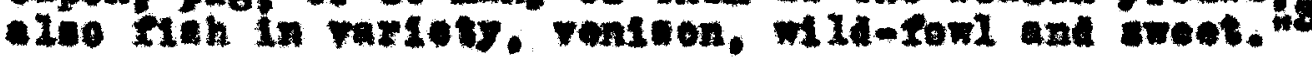

If Iikowie montion that gontlewen and arohente contented themelven with fonx, five ox alx dithee, of there be no geate. With three at moat."

The Alnner that foung lionel pland with his serwant. Relgnald, in the gusleh Treveliex by Hormood, is probably

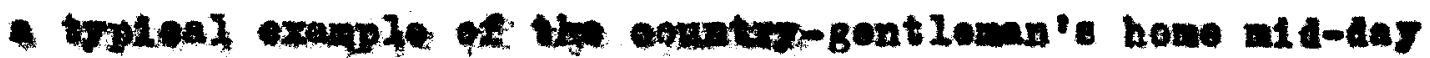

1. Bose Bradiog, opeatt., DP. T2-73.

2. Henry 1. Stephenden, The Fllzabothan People, op.alt.. PP. $897-390$.

8. Willin Harrieon, onelt., p. 68 .

4. Ibre. P. 80. 
"the poor whioh 110 ready at the gated in great numbere to receive same. ${ }^{1}$

Af ean be noted from the memal of the periol, the greater part of the diet of the upper alessed oonstated of fleah. By far the mejortity of reforenoes to food in the Iiterature of the period eonoern meat - "portly weat, bearing, aubatantial atnet, and 11 for bangor."n2 an

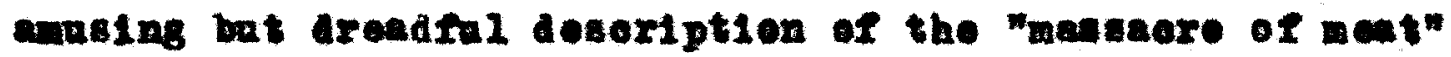
that took place at Ioung Honel's reant, Ia retallod by

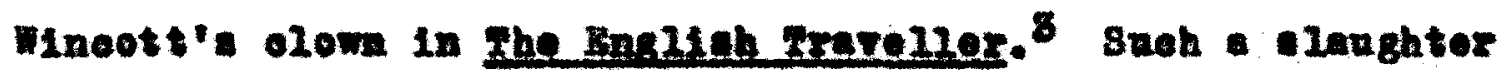
of fowl, fish and flogh is appelling to a modern reader. Unfortanetely, the Irosh moat al ot of the Blisabethans was interrupted in winter, alnoe it was imposalble to put down onough fodder to keep cattle fat and degirable Ir Dorember until apring. Uartionas day (Iovember IIth) wae the day for the axanghter of animals. The beat way selted and amoke-dri od in the farmoues ohlmoge for winter. Countlowe are the alinelone to sonsed or piokled meat and to arted or powdered moat. 4 Say George in The Pinner of Wakefiele by George-a-dreane:

Why then to honour George-a-Greene the more. Touobuate aleoe of beot at $\mathrm{w}$ poor hones;

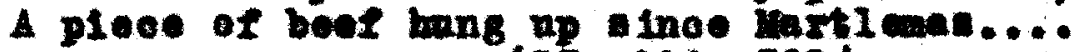
(II, 111, 369)

1. F1111an Harrison, op.ett.. p. 88.

8. Beavmont and Flotohor, loxk, opelt., The Knight of the Burning Peatie, (II, 2T, scol.

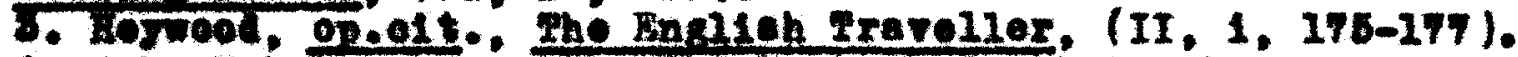

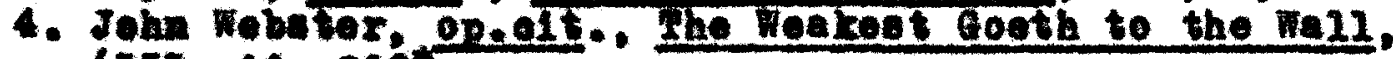
III. 11. 260). AIse- Bearmont and pletoher, the Sea Vorage, (III, 1, 889 ). 
Chough in A Ma1r ganrrel by Thowe Middloton waya to Tapons:

Tou rasty pleoe of Martlomas baoont (IT, 1, 260)

As william Harrieon has reoorded, beef, antton, vea1, lanb, k14, pork, conor(rabbis), oapon, plg, venison, and geese wore all ineluded in the English diot. Bent wat caton 1 th anatare in thio poriod, for in the raming of the Shres. Grande quostione Katharine:

What eaj you to a plees of beet and wretard? (IV. 111, 28).

The Bnglish love of antton with oapors extonil baok to the

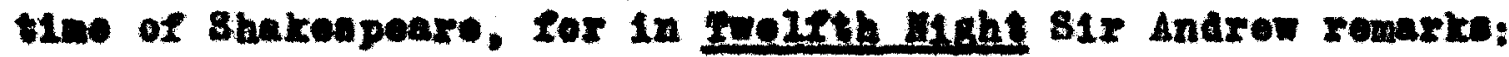

Falth, I oan out a oxper. S15 roby: An I can ont the mitten to it. (I. IT, I29).

Roant pig was a delleacy partionlariy onjoyed at St. Bextholonow' Felf, the goened of whioh are deseribed at Iength by gon Jonsen in his play of the wane naw. There pls "roanted with IIre o" juniper and rosemary branohod," was the food of the aly. Vosl, caten with "green sapee" sowed to have boen prisod as good dish. Allwit in A Chagte

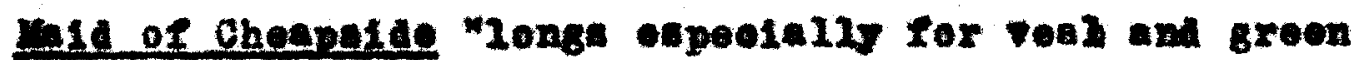

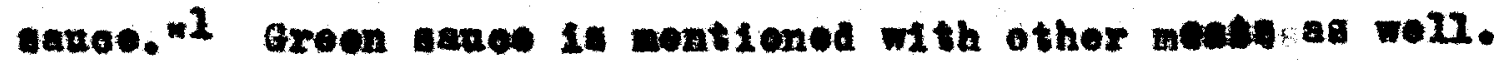

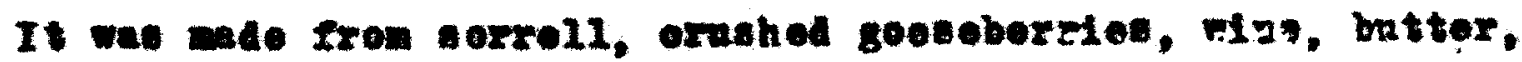
1. Thoma Hidaleton, op.oit.e (II, 11, 197 ). 
and the orer-present engar. 1

Rosst capen and ohloken were farort te eupper 11 shen. Both in Shakospeare and Beausont and Pletober play, "ohort-logged hene" aeen to have been proferred.

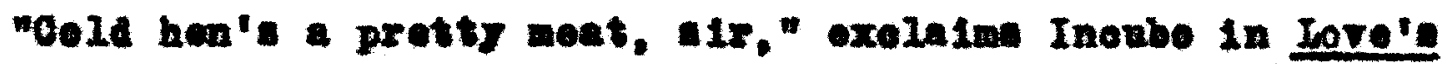
Pligrtese by Boanmont and plotehor. ${ }^{2}$ In fact, whon one roade through the desoription of meale both great and andI and roalisen the plece that meat hold in the lagliah liet of the 17th contary, the words of callpse in The Goerdian eppear to beve beon the exproaston of a national centinent:

'rie polnt of follt To be coy when moat it wet before yout (III, T. 28s, raseinger).

Cullie is a broth that ia mentionod a groat mans tines in the playe. Aceording to note, "oullie wat a utreng and aroury broth of bollod moat, otra ined, for dobilitated pereons. aomotimos made with a plece of gold anonget ite ingrealents. " 8 Probably this was the potent brew that Furnace, cook, alxod for his joung wastor in A Yer war to par 014 Debth by vaseinger:

Furnace: ...............the Ingredienta are cordial, And this the trae elixir: it hath bellel

sinoe mindght for you. 'Tt: the quinteasenee Of tive oook of the game, ten dosen of aparrowe Knnolles of veal, potatoerrota and marron. Coral and ambergris........

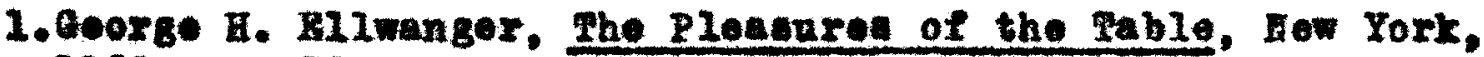
1908, P. 278.

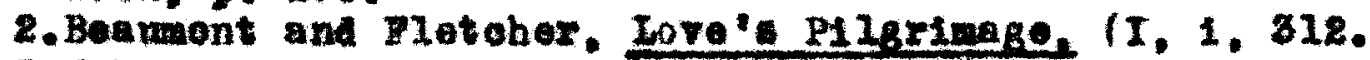

8.John wobster, op.e1s., Fo1. 2, p. 196. 
..... I warrant jod, though your journej's Iong. Ion way ride on the otrength of this till tomorrow morning.

$$
\text { (III, 111, } 160 \text { ). }
$$

Bremia was bread soaked in Bxavj. It was probably nsed es a meat extend or by the peorer people. potillut, the Roman eaptatin, oalle the Bngliah noldiere in Bondnog:

Io enting rasenis whose gede are beet and brewiet (I, i1, 22$)$.

Piah is nover apoken of with the ame ardor as I6 meat in Blisabothan literature. In order to holp tho

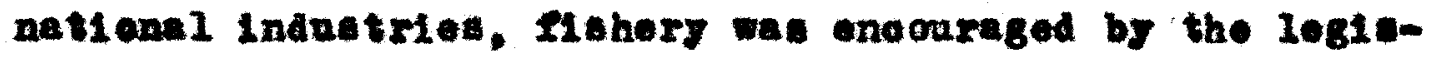
lative enforcements of tante. Recorde in the kilsabethen Joarmale Iad loate that the afty tethers hed some diffienity in onforolng the statuted prohibiting the os and nee of neat on suct ags.

In creen Hilsabeth's time the papiete were hela to be onendes of the geverment. "Hemos the proterbial phrese of 'Ro'e an honent wan, and cate no rich,' to signify that he'a a Iriend to the government and a protestant." ms

1. Also vasingor, the Goardien, (I, 1,198$)$.

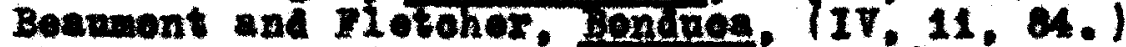
Ibid. Tolght of the Burntriketis, (II, 17, 857).

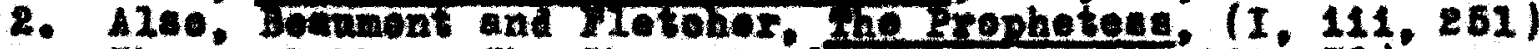

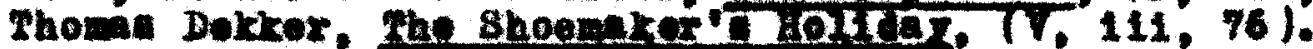

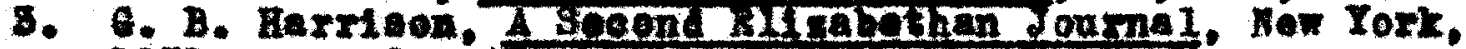
1981. pp. $28-43$.

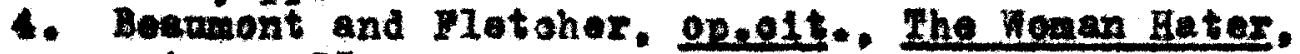
note p. 95. 
In Mak Ieer one of Xent's reason for wolf-reoomenda-

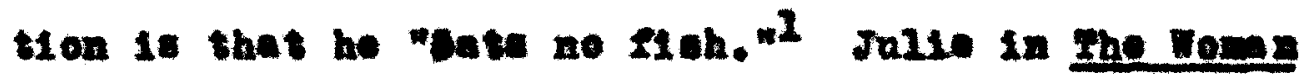
Bater by Bownont and Yletebor exilaina:

H. Ghonla not have eaten andor wy roef for twonty ponnds: an ourely I ald not like him when he oall'a for rish.

$$
\text { (III, 1, } 66 \text { ). }
$$

In The Dateh Courtecen by inxatom:

I trust I angone of the wiaked that eat 11 in Iryar.2

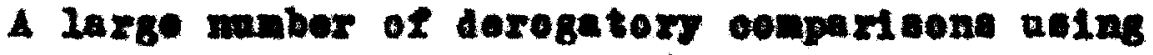

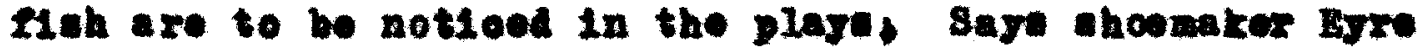
12 the ghocmater's Follay by Bokkex:

You sonsed gurnot! Amag!

$$
\text { (II, } \%, 24)
$$

Yon dog-nyzin-2aed rogue, pilcher, you Poor-Johnt

In IHenry IX, Foletare vaye to the Prino:

.......... rou way bay lana now as ohoap as atinking meckerol.

$$
\text { (II, 17, 804). }
$$

4 falt dinner of coremony show the wide vartety of Itah avaliable at the tine:

1. Shakewpeare, Xing Ieax, (I, 17, P. 1059 ).

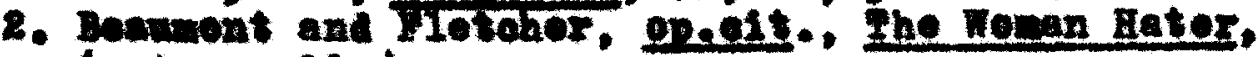
(note p. 96.)

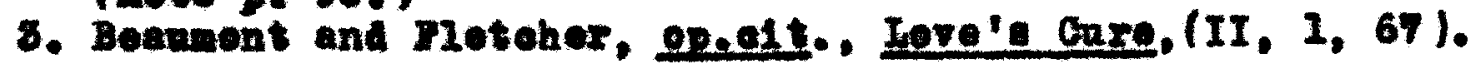


Mrat Couree

Oratero 12 in ecasen

1. Butser an egga

2. Barloy pottage

8. Stewed oraters

4. Buttered esge on toant

6. Splnaoh sailot boli'a

6. Bo11'd Roohet or Curnet

7. A julo of Iins

8. Stewed carp

9. Oruter ohowite

10. Boll'a PIre

11. Rost Boin

12. Haduobs and froah Cod or Whitinge

13. Boel or carp Ple

14. Dade ai oh of Spinach

15. Salt Bela

16. Sone' a Turbat
Seeond Conre

1. Iriod Solea

8. Stewed Orater. in Soallop Sholls

5. Iried 8 melta

4. Conger's Head boll'A.

5. Oyeter plo of potatoca

6. A Spltohood of Bala

7. Pinee P1e or Taxte royal

6. Buttered craba

9. Friel Fonnder.

10.Jelon of Jrosh Salmon

11.Jxied Tarbot

12.0014 salmon P10

18. Dried skimets

14. Bono't Conger

15.Jobuter

16. Strargeon 1

Cortalnly there was no coarth of a goleotion.

Doubtloas the Engling alused in livh the hoarti-

nose of mont. Thoy may bare bellered, as ald PhIllp II

of spein whon bo gare at a reasen for not eating rith, that "They are nothing bet elemont congealed, or a jolly of watex." ${ }^{2}$

A Ilah was not highls obteemed and as it was rery obeap, it wae the mainstey in the diet of the poor. Stook-tiah (aried ood-tioh) and poor-John (selted bake) were eaten the year aroand.

Vegetabled oceupled a rery insignifteant place 17 the Blisabethan nonn, althoogh the nee of "herba" bal Inaressed sinee the deyt of Henmy VII, when rege-

1. J. 0. Anarewt, opeaft., p. 98.

2. Ine. p. 98. 
tablea were "supposed to be a tood more fit for hoge and

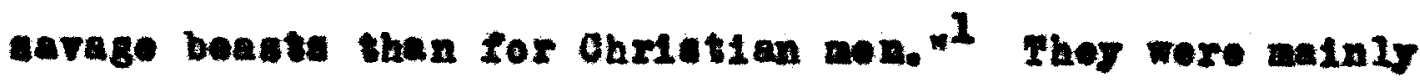

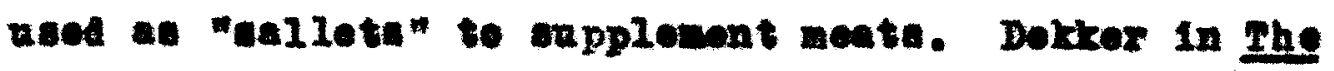

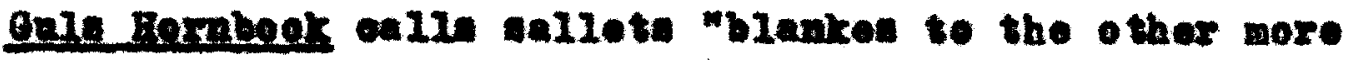
corriosable dishen. . $^{2}$

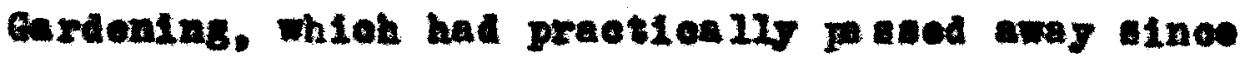
the Were of the Rosen and the aldeglution of the nonasteriod, was being rovited. Oabbaged bad reoently oome into zngland Irem Hollnnd; and carrote, lottuoe, rbuberb, artichokes, ounliflower, potatoes, and tomateen had been Imported alnee the beginning of the 16 th eontrury.

4 slance at a mom for Chriatane day as given by Robert ray in his book, the secempliuhed Cook, or the art and yatery of conkerx. pabliahed for the third tiw in 1671. chowe the unimportent role that regotables played in the dietary of the period:

\section{Bu1 for Chriatean Der and how to pot the rat} Inonar

1. A ooller of Brawn

2. Stowed Broth of mtton warron boned

3. A grand Sel1 $\alpha$

4. A pottage of eaponets

5. A breant of real in heffade

6. 4 belle partriago

7. A oblne of beef, or alrioin reast

8. Minead plos

9. A Jegote of matton with anchore canee

10.A wade aimh of gmoot breads

11.A aman roakt

12. A pasty of renisea

1. I. 8. Davis, gpegt. pp. 81-82.

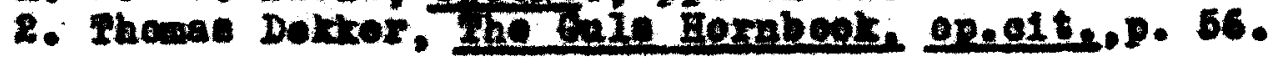


18. A kid with a pading in hia bolly

14. A ateak pie

16. A henoh of reniegn roated

16. A turker roant and atnok 1 th olored

17. A made dith of ohtoken in pref pate

10. Twe brongeene roasted, one larded

19. we laze oapont, one lerded

20. A onatara 1

"Salleta" were of two trpes - Elople and grand or oompond. The simple kind was generally ade of a olng lo "herb" or regetable, bolled and corved wth vinegar, o11 and sagax. A grant "ballet" was a mixture of "joung Deds and knots of all mannor of whileaone Herbe at their I1ret epringing," afxed with red ante, mint, lottree,

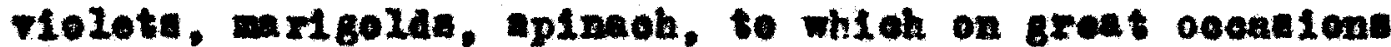
wore aded almonds, rainine, IIgn, eapors, ollros, cerrante,

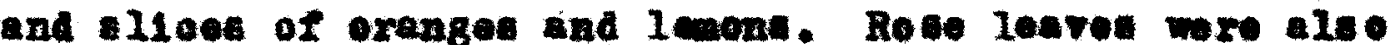
often used.2 Both trpen of "aalloti" ware more zogarded ae decoration than foode for getters eating.

In Bendece, Benamont and Fletoher, Petillius ingatres ceorntu11y:

Are sallade fit for soldi erat (1, 11, 26$)$.

In Dokrez's Morthuard Hoe. Bellanont atatea:

......he that I1rea npon Sallates whont

Mutten. Feode I1xe an oxs (ror hee cates Brasse, you

$$
\text { ì, 1. } 19 \text { ). }
$$

1. Robert Hay, The Aceegellahed Coex, Iondon, 1671, p. 12-A.

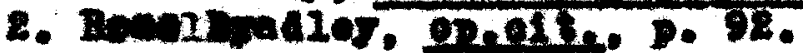


In The genct perzing by John Poxd:

Gan yon feed npon salade and tanat on?

Hat ilke an ase upen grase overy dar?

$$
\text { (II, 1, ) }
$$

OnI onh and garllo appear to have beon the favourite regetables of the perlod. Onlen, enltivated in oottage gardens in the reign of Eenry III and comendod by PIors P2owan, I were need in many waje other than an modicine and as seasoning. In Jolpene by Jonson oocure a rexy curlone paseage, In whioh six Politior-foule-Be tolle of his tests to deteraine whothes a chip newly arrived iren Bjria be "grilts of the plagees"

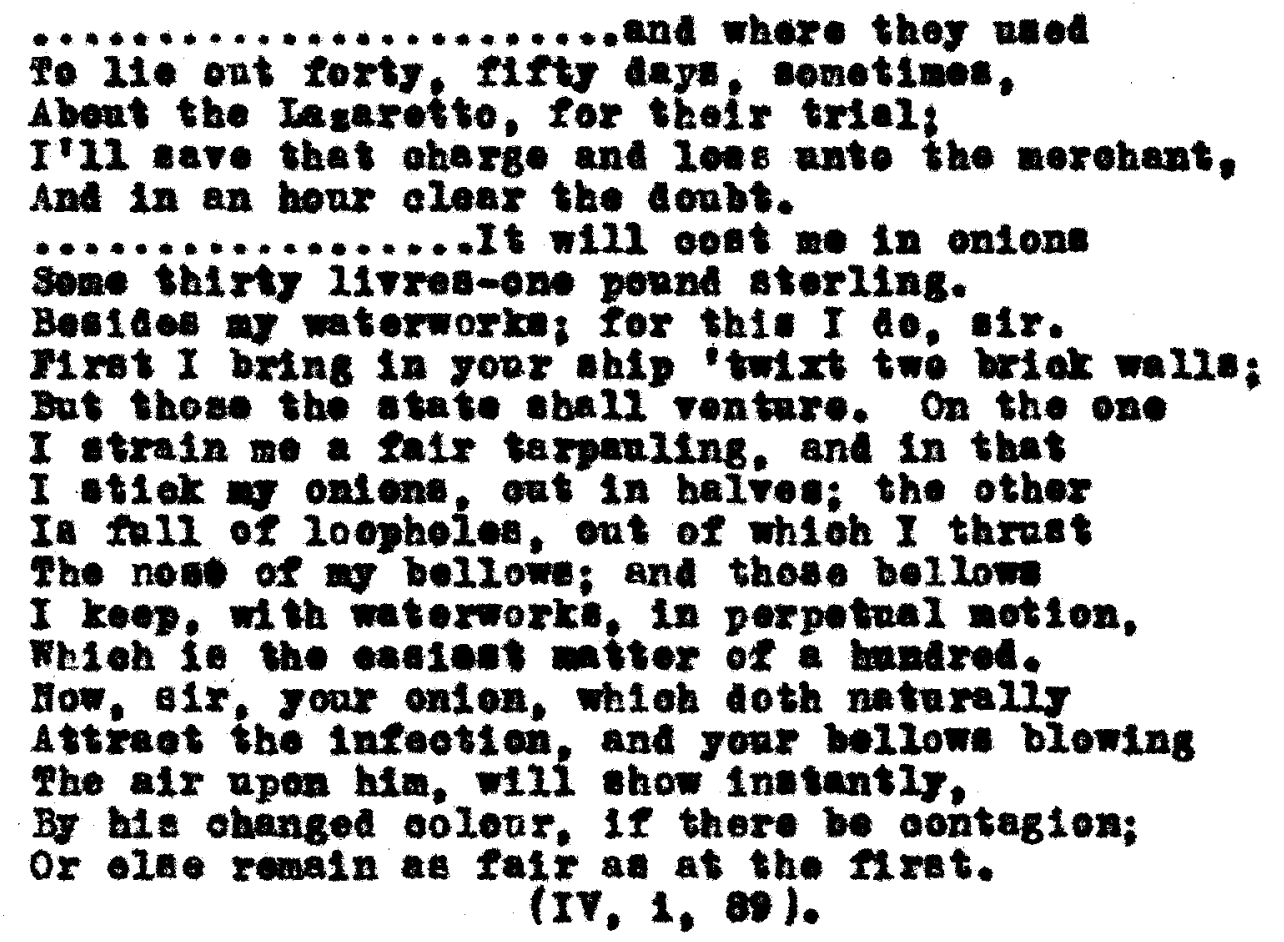

1. B. B. Tra111, eneolte, p. 489. 


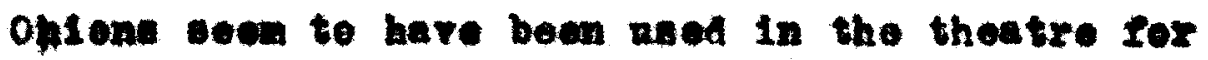

a reads oupply of teare. In the Taning of the Shrom:

If the boy have not a woman's gift

To rain a sowor of companded teart.

An onien wil do weII for snoh a mift,

Whieh in aplan belas olose convor'd

Shall in denpite enfores watery ore.

(Induction il).

4200 in inthon an cleenatre:

......the toare IIve in an onion that ebould water this earron.

$$
\text { (I. 11. } 176 \text { ). }
$$

Evidontzy onions and garlid bad the weos potonoy as now, for is A Maderger's whet prean, Botton gires this meming to bie rellowe:

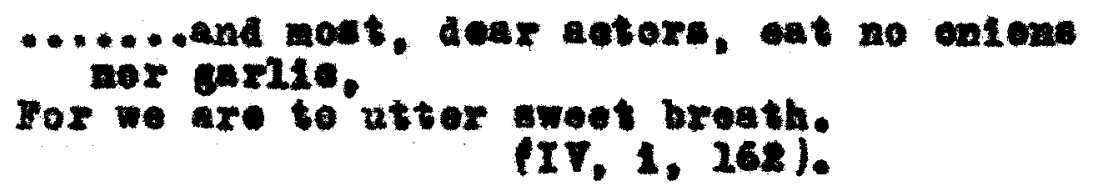

sif in Jobn Wobster' The Eleontent, Intriges in

- Ltsle whimer:

1 have an exoellent thought. If ace Ifty of the Crealans that wore oramed in the horel's boll bad eaten garile, do you not think ob

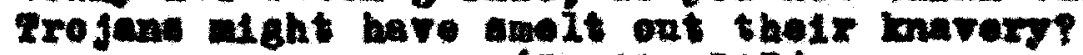

$$
\text { (I. 11, 14) }
$$

In Weatrenche by John Wobnter:

Doll to Bellawont: If you have a woet broath, you way drew nearer.

Bellamont: I an no exi ond to garile, madem. (III, 1, 215). 
An anknown poet in the Phillosepherta Benguet. 1688, growe thoetions on the snbjeot of onions cal garilo:

If Leokes Jou 11ke, but do thoir anelie dis-1ecke, Eat Onyona, and you shall not anolle the Leok: If you of onvons wonld the acent expelle. kat Garilgke, that bail drowne the onrena' and 12.2

Both onlone and gerlie appear to have been eaten raw along with bread or obeese. States Hotepur in I Henry IV:

\section{I had rether 1170}

with oboese and garilo in a vindill, far,

Than feed on outes.........

$$
\text { (iir, 1, } 162 \text { ). }
$$

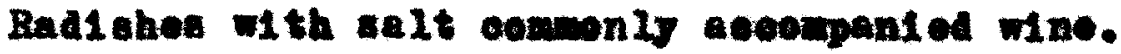

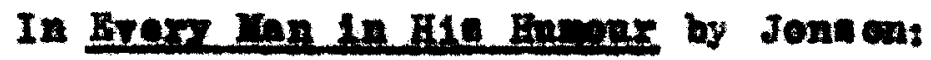

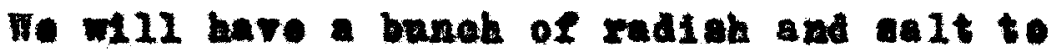
tale onr wine.

$$
\text { (II. 1. 40). }
$$

William Harricen writes of the ner regetabled ont of atrange oonntries whioh the nobility "adrenture upon.....eame of whioh are dangeroun and haxterl sxoh a mushroom. "R Along the same 11ne, Gerard'" Herbell quoted Celen, who has effired that manroom are all very oold and woist, ond therefore to approach unte a renomons and

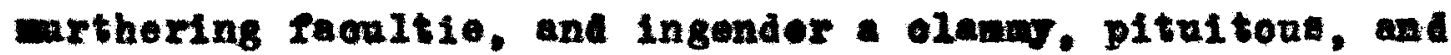
cold mtriment if thog are enton. To conolude, for of then

1. George H. Ellwanger, op.elt.. p. 106.

2. W12liam Herria0a, op.ati., p. 26 . 
are good to be eaten, and most of thes do exffoeste and otrangle the eater. Therefore I give ay advies nnte thoge that lore cuoh atrange and new fangled weated, to beware of 11 acding honor among thomed, leat the oweetnosse of the one do not countervalle the shaxpnese and prioking of the other. 1

If gardening bad been negleoted before the time of Blisaboth. Iralt-growing in Fngland had boon onoonzagod. Apples and peara grew in great varioty, an ald plum, peathes and cherries. During the pudor period orobarde ware enppliod with aprieot, alnond, poech, 18 and oornol treon. and there wore even efforts wade to grow oranges and 1 enons. 2 Irulte are frequently mentioned in the plere, espeolalls as part of the areat course at alnner.

In the Herce fires of Fincsor, swans it made to

as:

I will ma an end of ay ainner: there's plppine and oheose to oome. (1. 111, 389 ).

Apple-johns, a kind of apple that kept two yeara bat whioh beoame wrinkled and withered, are reforred to aevoral timoc. Saye Palatafe:

I an whered I1re an old apple-John

In II Hanx IY, Shal 100 apeake of theee apples:

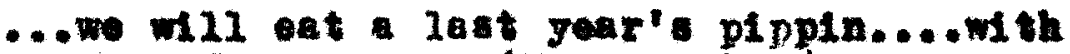

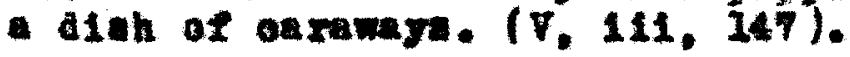

1. John Gerard, op.01t., p. 248.

2. W11lian Harrison, op.01t., Forewords, p. xadv. 
Pranee were not held in high esteca. Falataff in I Henrr IV, say acousingly:

There 10 ne more faith in the than in a atewed prane.

$$
\text { (III, 111, } 129 \text { ). }
$$

For some reason, prwnes were always somodated with brothels in this poriod and often dishor of them were placo in the Findowa.

All lood was highly seasoned with spleos. Futwegs, clores, ginger, olnnamon and many other kinds of eplae were oredited with modielnal ralue. In Cerrseo warkhen's

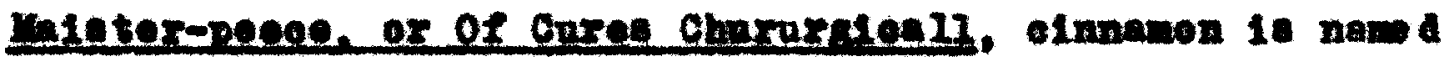
as comforteble in all inwara alakneases. 1 cloves be writea are "very comfortable to the inward parta." 2

Intmegs were senetimes gilded and carried as $10 \mathrm{re}$

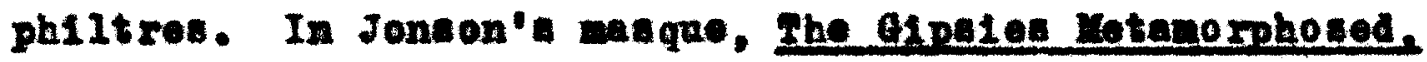
Yog wat 18:

And I have loot an enchanted nutmo8, all gilded ovex. was onohanted at oxford tox mo to put in wy oweet-hoart's ale a' morning .8

Mention of gilded notmoge and ginger also oocure in the Affentrongte Shemherd. 1694, and in othor poent of the period. 4

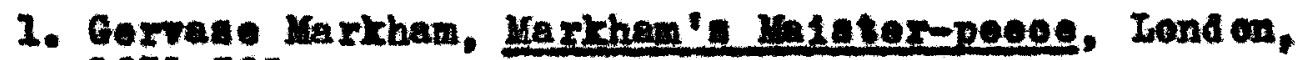
1681,662 .

2. Ibl, p. 668 .

3. Jomben, enciti, p. 404.

4. Ibil, onealt.. note p. 405. 
Uerrythonght of The Knight of the Buming Pestle elat mo that:

Intuege, and ginger, olmanon, and ozoros, care we thie felit red noce.

$$
\text { (I. 111, } 172 \text { ). }
$$

O2 all the "uale dishog" on the Blisabethan table, plea of ald liade were the most popalar. Brexy ereatnro of the ar, the eed and the land appere to have been pnt Into orust. Fot only was alnost owery spoelo of the aninal LIngdon age inte a pasty. but tho vegetable realn too was we11 represented. After a readng of the Bligebethan eokery booke. one coneluden that besiden the luevitable sugar and

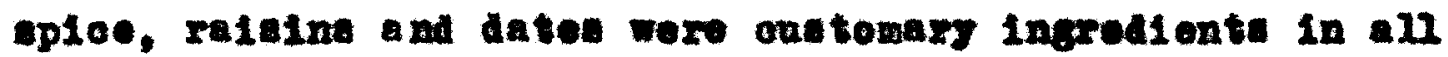

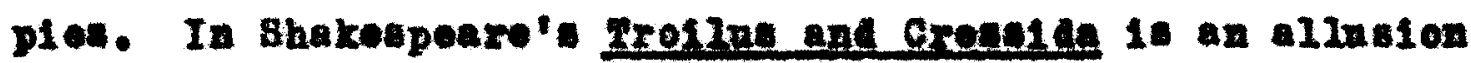
to the ever-preant detes

$$
\begin{aligned}
& \text { AJ. alnoea nan: and then to be baked } \\
& \text { With no ates in the p1e, Ior then tho } \\
& \text { man's ate is ont. } \\
& \text { (I. 11, 279). }
\end{aligned}
$$

Iads Deyalet in Reme an InIIet oownand the marae:

Hola, take those kega, and rotoh more epleas, Dares Theg on 11 for aston and quinow in the pentyy.

$$
\text { (I. 20. 21. }
$$

When the pie arust for the fliling oovered the sial and the botten of the atoh at well an the top. the 
peety wat then oalled "ooffin." An old roolpe

gruesonely inatruete how to propare a ohioken pio:

To bake a obloken pro, aftor jou have trat rour hioken, then broken thelr ioge, and brest bones, and rasted your eruat of the best pate, jom hall lay then in the oorrin alose together, with their bodren fnll of better: then lay upon thow, and and erneath them, ourrents, grout Ralsind, Prunet, Claanon, Sugar, wholo moes and salt; then cover all with great otere of patter. and so bake it, after ponre into it the wane IIquer you die in your marrombone pre, with roiken of two or three Bgge beaton anongst 1 , and we cerre it sorth. 1

The liquer rexerred to is white wine, rose-water, oggar, olupamon, and Inegar atxed tegethert

So Inte the "oorrino" went bird, beat and IIsh; Irnit, regetables and oustard. In The rening of the Shren,

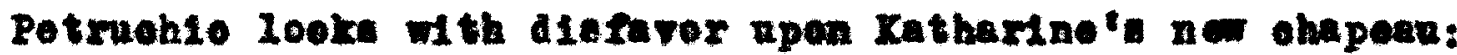

Why. thor eay'at trae: 1 is is a paltry oap, A onetari-cormin, a bauble, a siken ple. (IV. 111, 81).

In Itue Androniens in a mo moabre referenoe:

Titus:

I'II were peste, And of paste a ooffin $I$ $\mathbf{1 1}$ rear And nake two postioe of jour chemeful hends.... (7. 111, 288).

It It waid thet the word coffin wat in 111 repate nnder Bli saboth:

1. 81x Ieneln Digby, The Closet of the Reinently Learned

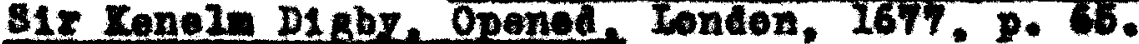


The good queen as the oull for one to 1 aclose the deerest noreel of the earth beoame nore preas1nf. grow wore eolleltione to oxalnde all thoughts of it. She would oblde ber lorde if they mentioned the oorfin of a pie before hor, and worla ake thon eng erast. Ior she lored not wo rab of sad con. I

Terte alifered from pies or pastiea in harlug a top oruet twiated late an opon-work pattera. Potrachie in

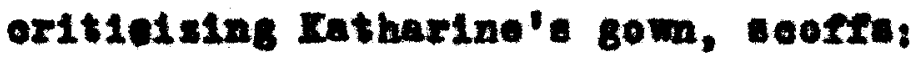

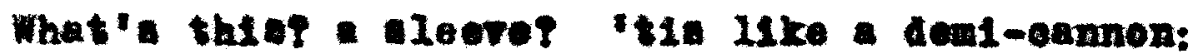
What, up and cow, ostrot like an apple-tart? (17, 112, 65).

quen Elisebeth we orten served with a large ple. Irom whioh, when opened. Iler a cover of bl ris. Tha Ifterally and hiotorienily ald the nursery rhme of the "zonz and twonty blad blrds" cone true. In Banwont and

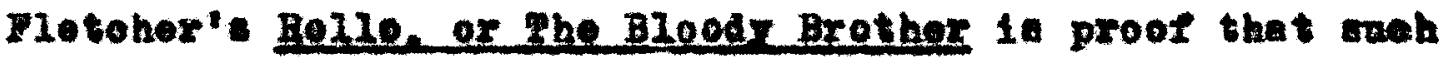
- pie exiated:

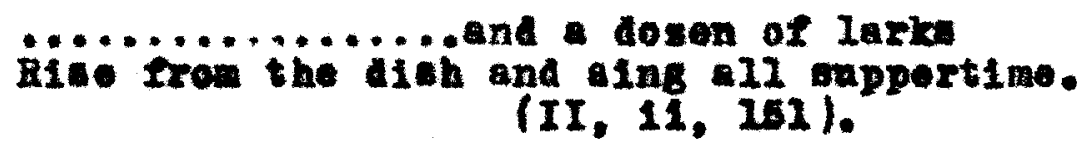

In an old is book of cookery has boen tound a novel and almple wethod of learentng the "pyes"

And now corot the cefty, bat enve a 21ttel hole. to blow inte the oexim, with thy month a cote blate; and rodenty atoppe, that the wyae ebrae whyme to rgee up the coffra that it fallo not to loma.

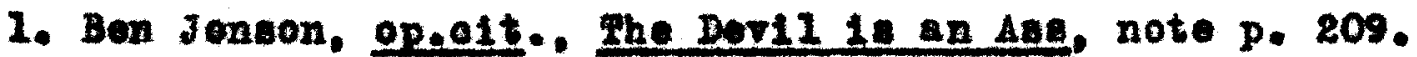
8. W1111an Shatonpoare, The Taninh of the Shrow. ed. by V. J. Relie, Iew York, 1898, note p. 163. 
And whet fasolnating ploture it makes a portir Blisebothan aook, his fat ohooke paxple with effort, as be blowe "a gode blast" into the pie to make the corrin nxyse ap!"

A oomen oath of thl peried wat the expreseton

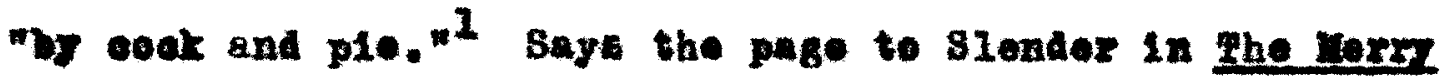
Eirec of windeox.

Do ook and plef Jou ball not choose, elx. (I. 111, 14 ).

Som think that the onth had its origin in the mentifient foaste of ohivaly whon roated peacock ras presonted to each knight who then mede his chosen rom. 2 Roseted pesoooke, used often at fonste by the llormans and nobles of the medleval perlod, were oomparatively rare in Blisabothan Bngland save on very fobtive oenasiona. It was onstemary to renere the plumge from the blra before roating. Afterwarde, the okdn and reather wore aewed beok on the cooked birt and Its comb wee Bllded. Sometimes the pencook was mate Inte a pie, at one ond of whtoh the head appeared above the orust in all Ito plameg, It hoef riohly gllded; at the othor ond the gorgeous tall was ranpant. In the 16 th oentury plotured of the cook and pit were comon 1 gns for a10 honsea.

1. Shateapeare, II Hong IV. (IV, 1,1 ). 2. Wr. J. Relfe, noteo to ine Temest. p. 157. 
The aajing "to eat hamble pio" appeara to have originated fron the prootioe of olling the 117or, kidnors, and other organe of the deor chumbles" - whioh portions always foll to the koepox, and honoe were Irequently made into pie. To ent humbie pie thea, was to eat not of the bost bat of the interior parte of the deer. ${ }^{1}$

02 all the etrggering variety of plen montioned in

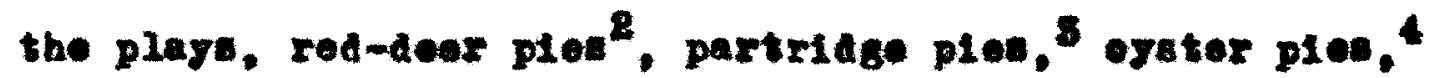
pippin pies, 5 warden (poer) pies, 6 turkey ples, potate

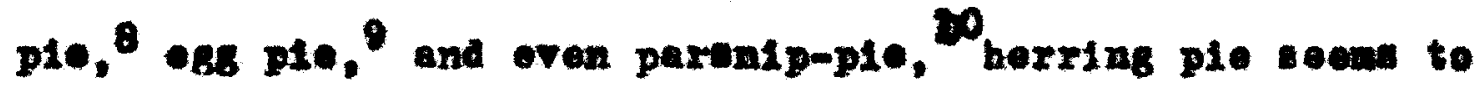

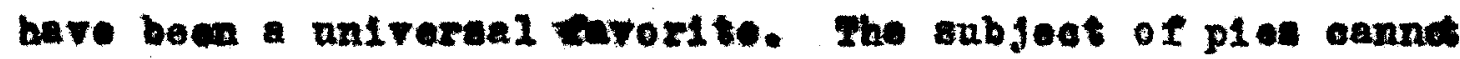
be aropped whthent a glanoe at a ruolpe for herring pie found in the Acooprisibed Coots.

Take salt herringa, beling watered; was thon between your hands, and you shall looks the fish from the akin; take oft the akin whole and lay them in a dith; then heve pound of almond-paste, two of the nilt or roos. five or alx dated, gone grated manohot, engas, sack, rosewator and saffron; make the composition somontat sti2t, and 1111 the nxins; pot butter in the botten of jeur pie, lar on tho herring, and on thom dates. goosoberries. ourrants, barberrios, anf butter, eloe it up and bake 1t; bolng bakgd. Ilquor it with batter, verjuice, and engar. II

1. Robert Oreone, op.elt., Irtar Booen and Irlar Bongar, note p. 348 .

2. Shakepeare, The Uerm pires of vinceor, $(I, 11,116)$.

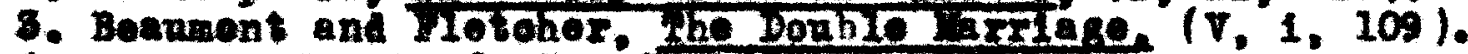

4. Jonson, exnthia' Rerelt. TII, 1, IST.

5. Beament sil rotoror. the suler Brother, (III, 111, 480)

6. Sha keapeare, Inter's ta T, TI, 8, 331

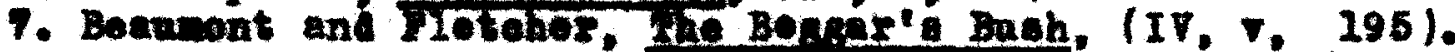

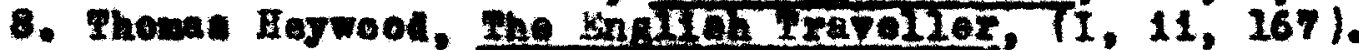

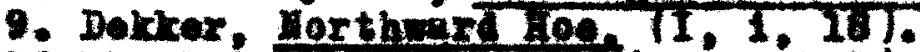

10.Mraloten, whortes, $(I, 1,121)$.

11.J. c. Anaromb, onel., p. b5. 
As has been before stated, the banquet or last oonrse of the dinner wa wade up of sweot dishes. Gapare requesti in the witeh by Madieton:

Please jou witharaw yourself to jong private parlour; I'll cend you vealson, onsterd, perenip-ple For banqueting staft, as anoxeta, jell1es, siruj. (1. 1. 181).

In the peming of the shrem the fanotion of the banquet in pointed ont:

$4 y$ banquet is to olose our atomath up after our great goed oheer.

$$
\text { (7. } 11,0)
$$

In Dokker's The Hiteb of Bamenten:

Oh, weet bital banqueting stufe.

$$
\text { (III. 1, 428). }
$$

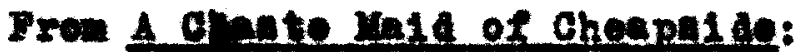

What store of angar, Hsoulte, cont1te, and caramge,

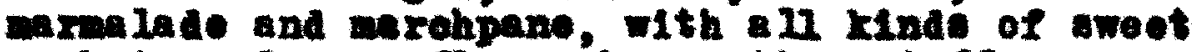
onoket: and anpernkous banqueting atnef........

(Dekber-Baohelox': Banquet) $)^{1}$

Ereryone was extravagantly fond of ongar as well as meat. Blaborate pastries were features of large banquete, as weIl as marohpanes moulded into fantastio shapes. Iontion Is made in Beapmont and rlotoher' wit without foner to tho "bullaing of marohpanes." Aotanily many of then wore arohiteotural aohierements. Warehpane was the priged oon1. Dekrer, Bachelor'a Banquet, note p. 211. 
footion of the day. The serrants in Rowee and Jaliet opear of it dneing preparations for the banquet:

Cood thon, save wa plece of narohpane. (1. 7.9 ).

In the Greet Dike of Lerenes by Maedinger. Petronelle says:

$$
\begin{aligned}
& \text { Here' a asetle } \\
& \text { Of ancoh-pane, toe. } \\
& \text { (IV, 11, 272.) }
\end{aligned}
$$

And in Middloton's Wonen Boware Women thore is a "oolt of excobpane. 1

Bealdes the axphpanes there wore oustards of croxy 150, thape and kind, "ffrty-angled" and plain. In Boawent and Plotoher'm A fife Bor a Youth, appeare a eastie caetard, a dish that was alwaye part of the eelebration of trinuph dayt

Wi th oat10-ouatarde.......... And thelr artiliers...........

$$
\text { (Proiogne. p. } 137 \text { ). }
$$

Qastrucalo in Bearmont and rletoher' the Dopble Yarriege compla ins of the meal proferzed hin:

$$
\begin{aligned}
& \text {.....no marohpanes, custard-reja1s, abtilitiesp } \\
& \text { An I plongh-man, } \\
& \text { That you pop up with porriage? Hane the } \\
& \text { cooka ? (III, V. I). }
\end{aligned}
$$

1. Thowes Midaleton, op.01t., Woen Beware Women, (III, 11, 278). 
Sabtil1t1es, figures and devieas, originally made of eugar or pastry, and later of palnted cardboard. wore arvival of the modioval dining table. They worely ropresented the dealre for color, which partis in Bilsabethan thes had its ontlot in the ooloring of food with caffrom and other dyea.

Custards wore enatemary at elty feastu; and in earlier days when the oity kopt a fool, it was expeoted that at public ontertalnmenta he leap inte an Imense bowl of oustard set for the parpose.

It way perobanee, in tall of a cherife' atmer Ske with then on the tablo, from Mow-nothing, And take his Aimain-leap into the onetard. (Joneon-The Derti ie an Aas. (I, 1, 14).

\section{Irewte in All's Well phat inde ne11, Jafon} ohidos Parolled wth having "run inte his diepleasne:"

You hare wade ohlft to ran into 't, boota and apnrs and a 11. 11ke him that leaped Into the custerd. (II. $\% .89)$.

Besided the marohpanes and outtards, there wore

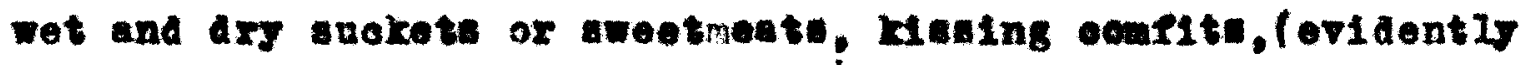

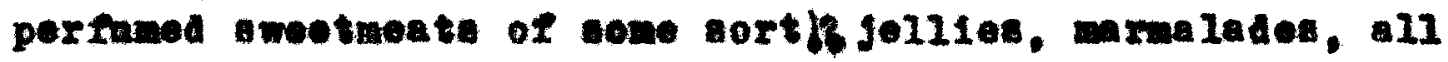
sorte of bleoniti and fruits, and often sliced oranges and lement to wake op the sweet oovree of the meal. At the merchants" great feaste, Harricon notea that the alshos of the bangret "inolude jellies of all 
colours, wixed with a varioty in the representatien of oundry flowere, herbe, troel, fozm of beaste, Iteh, fowls, and Irolts, and thereante warohpane wronght with no omall ouriosity, tarte of alvore mos, and onniry denoninations, connerves of eld fruits, forelgn and home-bred, onokete, oodinace, marmalados, Erohpane, sugar-bread, Norentinos... tre. ${ }^{2}$

It It nowensary to quote a dosoription of a banquet cerved to the Queen at Blvothan to give a olear ploture of the marnifleenes of boepltality offared by her nobles.

After apper, the two delighte prepared were

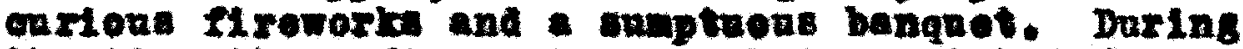
the time thene firemorita wore being watohed from the pond, two handred of the Barl's gentlemen corved the banquet, all in glans and allrox, orexy one arrjins eo mang alshen that the whole muber anongt od to a thousand: and there were to light thom In their way a bandred toroherw. The dishod in the benqret wore; whe eneen's armin and the axse of the lobility in engar work; won, womon, ousties, forte.

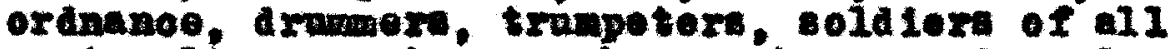
norte, lions, ani eorns, beare, horees, daneele, bulls. rame, doge, 1gora, lophants, anteloper, Aromodaries, apes, and a If the ether beots: eaglea, faloene, oranea, buetarde, herenchawn, bitserne, pheaseante, partriages, qual 2s, zarke, sperrowa,

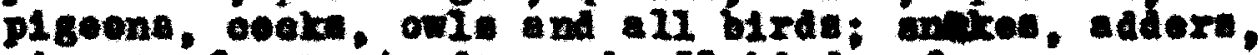
1pere. froge, teats, and a 11 kinde of norma; nerma14s, whales, dolphint, oongera, aturgeont, plres, carpe, breame, and 11 sorte of fiahes. AII of those were in sugar work, wow in atanding diahos, somo in hat work. Thore were aloo in Int sugax work and marohpanos, grapes, oyaterw, wateels. cookles, periwinkles, ormbs, lobeter, at weli as apples, peare and plems of all kinds, preserves, cuokete, jellies, leaches, wameladed, pastes, and comrite. 2

1. Wlilan Harmeon, op.olt., p. 92. 2. Joln IV17, Norka Op.017.,pp. 487-8. 
In the plenty of the Bll sabethen age, poor mon wero beginning to look for tinore ugat, and to expeot a great or variety than before. In the past eexving man wee well content with pieas af boef to last the whole weok 1ong. If thexe was enffiofont bread and beer to fill out the racsnotes. Brarywere, the poor ade the greater pert of tholr soanty meale on poor-John and other ant fish. For the countrymen, fowls, pigeons, and all sorts of game wo oheap and casily obtained. Milk, butter, and ohoese, whioh were knom al whito meats, "wore went to be acoounted one of to chief stays throughont the isiand, and are now," Barrison writed, "reputed as food only for the inferior sort. kany poor ahopherds lived on nothing but braed. "m11k, acor m11x, and moy,nl

In A Iooking Glasge for Jonden and Bngland by Hobert Greene, Aloon, a poor man whose aon 19 abont to bo taken from him by the uearor, aries:

Why, olx, alas, gy com 10 a compommalth to not for Arat, hix, whe allow me, w wife, and con, for te banquet oureelves withal, butter, oheese, whes, wilk and butter-milx.

Ho oov, sir! alas, that word 'no cow' goes as coll to wy heart as a draeght of gmall beer in a Frosty werningl 'Io cow,' Mix! alan, ales, Manter Uenrer, what ohall booone of mo, wife, and wy poor oblia?

(I. 111, 95).

Plowen a ad artiana on Tharsday and Sunday nighte cometimea hed oheap neeks and points of beef on their I. I. B. Ira121, ep.eit., p. 228. 
table, bet the raminder of the timo their alet oonsieted of rish. "white met, and a little beon. raneingor in the oitr ugan epcaka of folk in like oirorms tanee:

$$
\begin{aligned}
& \text { And nook of boef on sundars and livere, } \\
& \text { (I, } 1,400) \text {. }
\end{aligned}
$$

As contrasted with the Ine wheaten breal or ancheta of the upper classer. the leares of the poor oonaleted of barley and rye, otten supplemented when timee

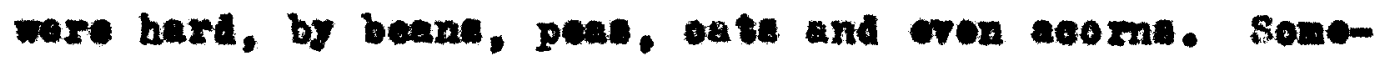
timen these loaves wore referred to at "hortebread" einoe horees at this time were often giren thoir provender ide Into breat. Saye Harrison: "Serotimes the poer labourIng man is ariven to content himbelf with hor 60 corm, beans, peas, oats, tares, and lontila, and therefore it is a trae proverb thet 'Hunger setteth his firat foot into the horse-manger." 2 Bon Jons on, in his Derchie, waken reterence to:

You thread-bare, horae-broad-eat1ng rasoald.... (III, 11, 188$)$.

Sometimed the bread of the poor we oulled "oheate." The Rarl of Oxiord in writing of the labouring $\operatorname{men}$ sa:

The manohet Ine falles not unto his ehare.g on coarter oheat his hangry stomecke feedis.'

1. H. S. Davis, op.01t., p. 81.

R. Ben Jonson, The Kagque of Augars, note p. 438.

3. Ibse. p. 483 . 


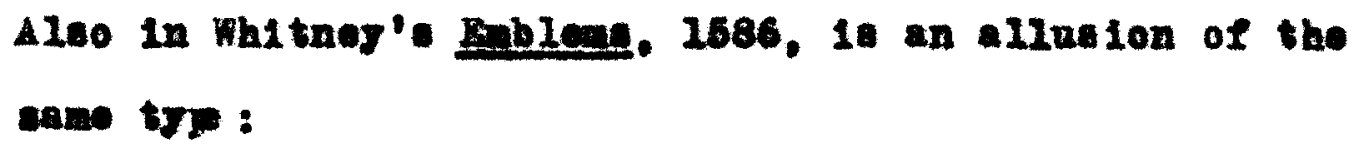

The manohet eine, on high eataten bontowe, The coerwer oheste, the bauer gort wet prove. 1

whe very poox, If they had an sore of ground whoreln to sot oabbagen, parenip, raliehos, oarrots,

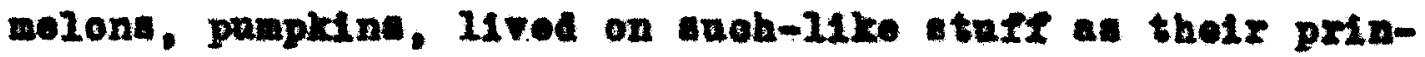
oipal tood." $I$ is interenting to note that the poor man's liet, coneinting ac it ale of mill produots, regetables and coareo gralne, wat woh better balanoed fron a motritional atandpoint that that of the rioh man. If reoerds were arailable, a fasolnating study oould be wade by oomparing the axpletion that betet the too-amply nourlshod with the discases vinited npen those of more meagor Pare.

The more prospocine country folk engoyed sueh broolie dosecrte as those in Jonsen's She Sad Shemhere:

Mall to jour cheose-onked, onrdi, and clonted orean, Tour loole, your tlawn.

$$
\text { (I, 1, 273). }
$$

Fools wore goeseborrien bolled and eaten with aroam; while flamn were onatarda. Aingerbread, of "oonfortable" bread wa also an unephletionted conntry cake."

1. Baa Jonson, The Hage of Apgare, note p. 438.

8. B. B. Fraili, opatt.. P. 689 .

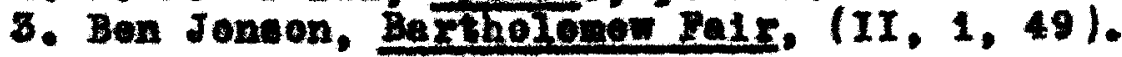


That's mot and arink to nol (Al Ioa Lire It, $7,1,21)$

In an age whon mon's thoughte anolt so stoadiy on the ereature conferts of 11fe, It is to be expeoted that wany of the proverbial expresations of the day conoerned food. Se Alled is the literature with thede atrerting and pertinent collopilaliane, that it is oxpecdingly hard to plok and ohoese. Somotiwon the sajinge are topien, wi th the meaning obsure, but more often the allutione are ameingly cex-ovident.

since roat beot wa belored by the Rngliah, it netural to flnd it reprosented in the combon expreasione of the day. "Oh, w ewot beefi" say Faintafe to the hoateas of the Bonr'a Hoed. 1 "raxwell, and ory not roant beef," Whioh means to boast of anything jon hare so at that another sball tako it fron jou, 16 found in Beaunont and Fetohor's The Litle Irench Iancer." "Tou ofvil aish

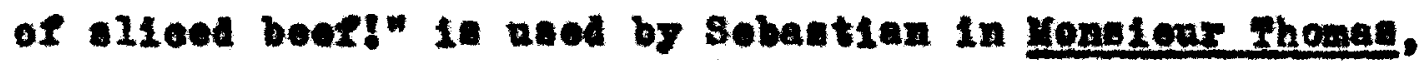
Beamont and Wlotohor, in apeaking to hil con. 8 sinoe ohiaken wa a dish held in high favor, wohioken" uned in referring to a persen 10 a torm of affeotion. "Bo very worry. ohicken," anje Tony in A Wife fex a venth." "Alas, poor onlekeal" in Bonduen."

1. Shakenpenze, I, Hezry IV, (III, 111, 198 ).

2. (II, 111, 164 ).

8. $17,27,819)$.

4. Boarmont and Flotoher, onset., (III, 111, 194 ).

6. Ible, Bendnes. (II, 11, 87 . 
Torm Involving lab wore gonerally inoulting. "You dog-akin-taoed rogue, plloher, you Poor-John! -1

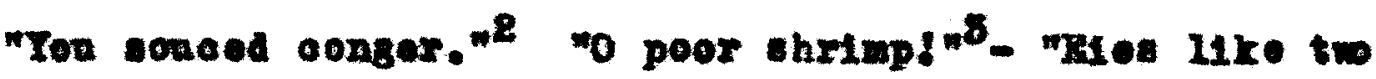

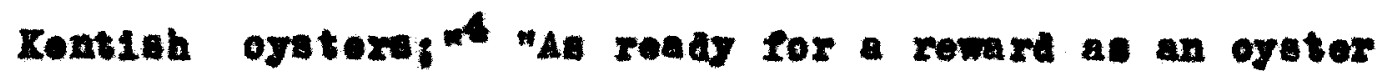

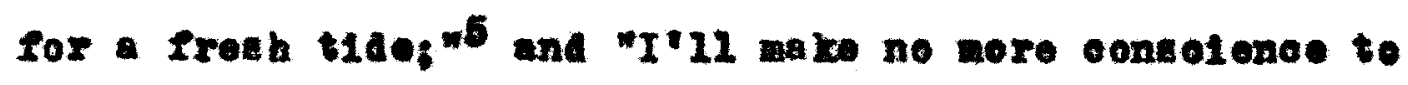

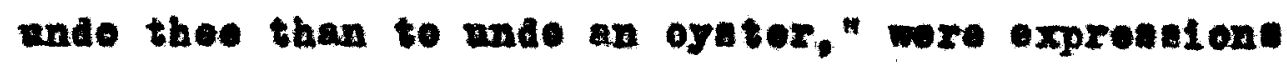
dearing with wee roode.

Bger and dal op prodnote are wil ropresented. "I'11 walk on egga thie paee " "W111 jou take egge tor

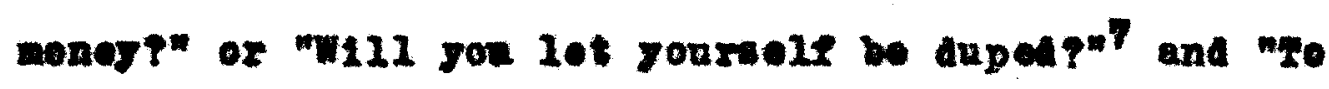
hare agge on the aptitn which noan to have businese to attend to, conelude the 988 gronp of phrased. "I rnow what 's whot. I know on which alde w bread 14 bettered,"

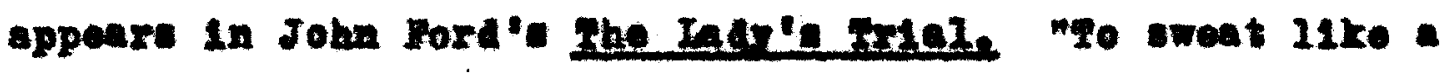
bntterbox," was a commen exprositon, as we "an honeat butterbox," 10 meaning a Dutohman. "I looked pele as a now

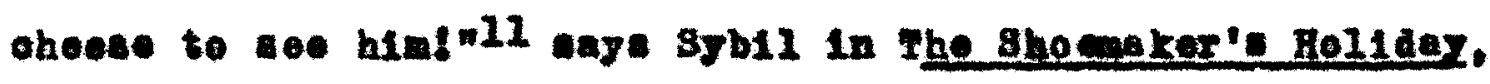
end "You Banbury ohene:"12 oried Falatate to slender in The varm wires of indaex.

1. Bearment and Pletoher, ope1t., Lave'g Cure, (II, 11, 416 ).

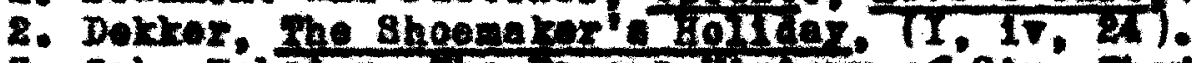

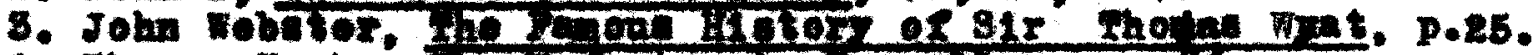

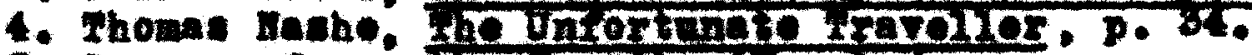

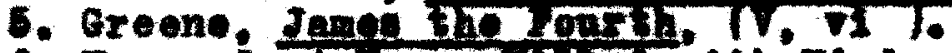

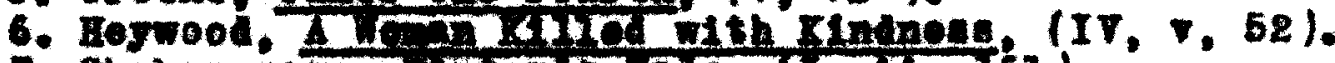
7. Shakea pexro, wrar Tar, TI, 11, 161)

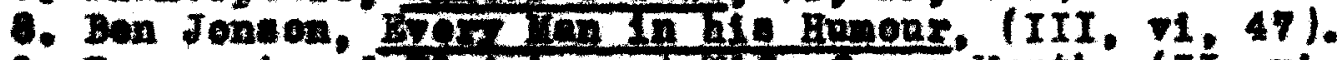

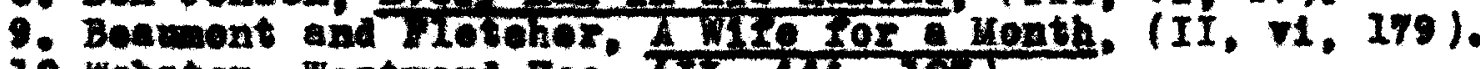
10. Wowstor. Weatmax! Boe, TII, II, TOST.

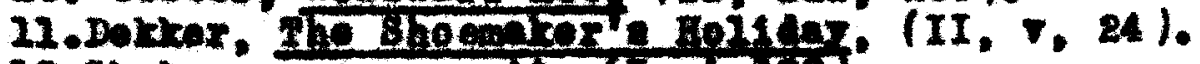

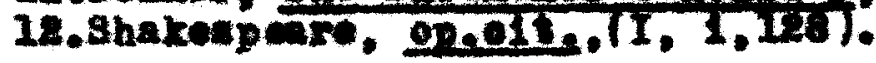


Woodooer was a pogmiar term uad sor a poreon ntterly brainiose. 1 as ma "Tos oueturd patel to indionte a tood. ${ }^{2}$ those with mitse at thiol as Tomronbary matara, 8 woula aldo not be mown as too intelligent. "Hore's an

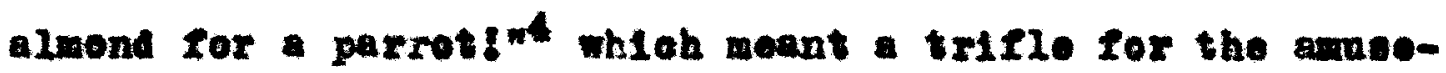

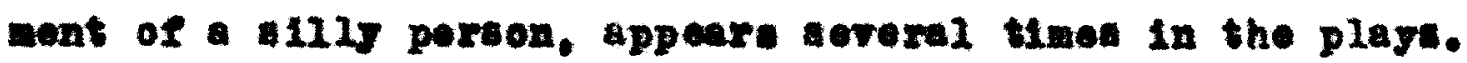

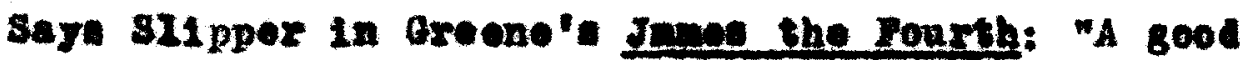

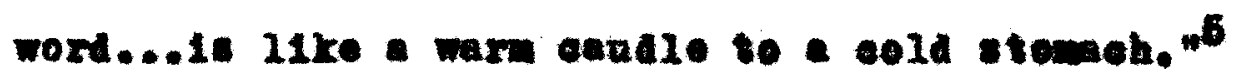
minobroon" wa nat to tndieate nows and quioly nade geationan. mhat we thenla thoep to and a mabroong 6

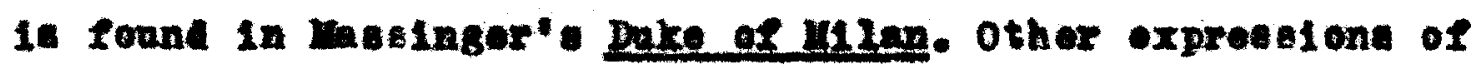

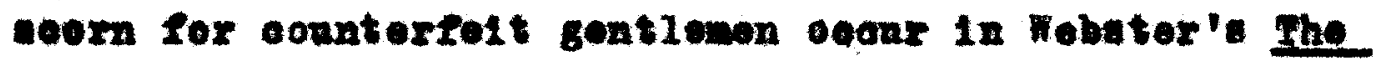

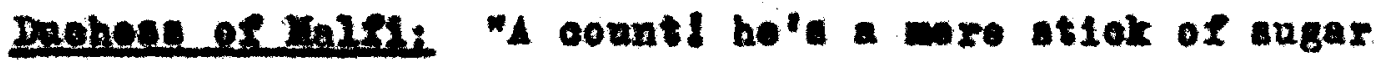

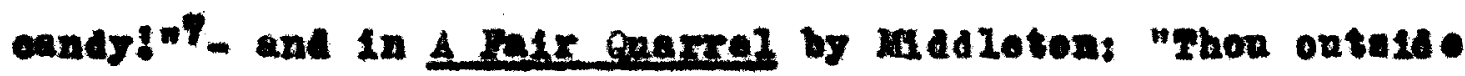
of mat thon etmunon troe, thes bet they barl hast nothing good about theogne

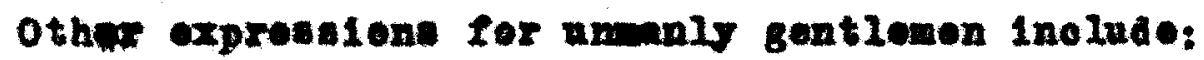

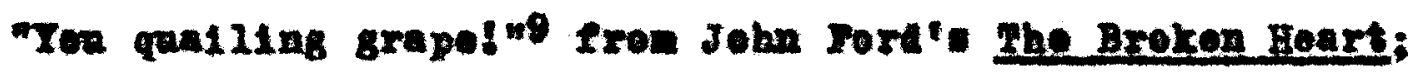

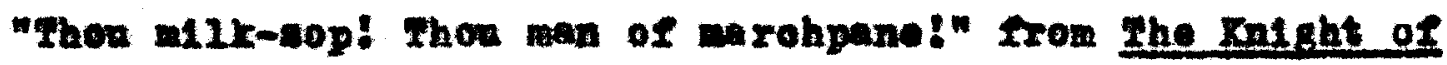
Yulte: and "he nexte 11ke mamalabed"10

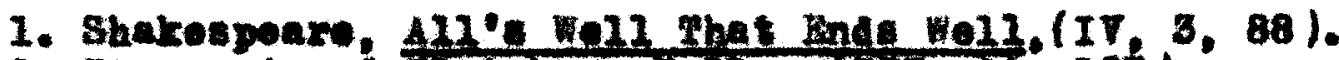

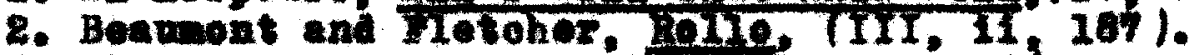

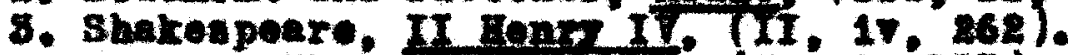

4. Delrex. the font whore. (7. 11, 105$)$.

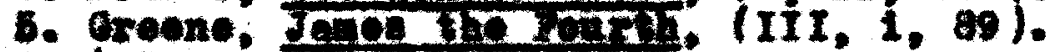

6. (II, 1, E).

7. (III, $1,20 \mathrm{E})$.

8. (III, II, 249).

9. (IV, 111, 158).

10. Beamont and Ietcher. The chaneeg, (II, 111, 47 ). 
Phrases ueed to exprese an involvenent of affaira are: Wy hand was in the p1e, w lord."1 saye oriande to the Dake in Dokker' Honeat Thore. Vow Ponolope Whorehound in the seme play: "I wat nover in this ploklo before."i2 what a cold piokle, and thet none of the oweeteat, do I Iind poor celf ing" oomplalns lalfort

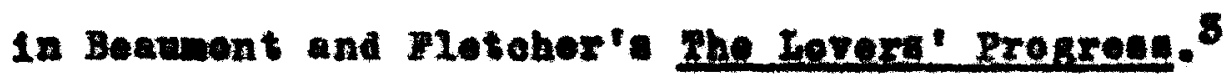

"Ion need not be so exustieg gon axe not we hard bak't, "t deolares Silone of yether Bombie by John inly. "You pests tooted raseal:" mon yerthrext Hoe desoriben a petty rogee. "4y braine wi11 work without barm, "6 from The Hronou Ileatenant. Barm was the old word for yeast.

1. Dekker, The Heneat Whore, (V, 11, 274).

2. Ib1. $17.11,2 \mathrm{~d})$

3. TIV, 111, 515).

4. Johi I015, Yother Boeble, (II, 111, 190);

6. John Wobetor. Lorther hoe, $(x, 11,208)$.

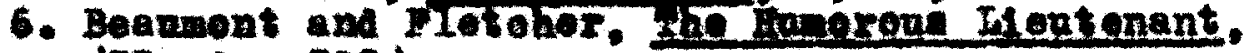
III. iv, 890). 

GHAP TIR III

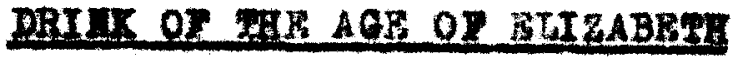


"Cood arinte $1 \mathrm{a}$ a matalne por all aleeases." (The Difortunate iraveine).

In this proal gal ar of teaeting in lingland, toa and ootree were untuown. bet whe nowed into the conntry Irom a11 Gurope. Phere were orer a muared varieti en on

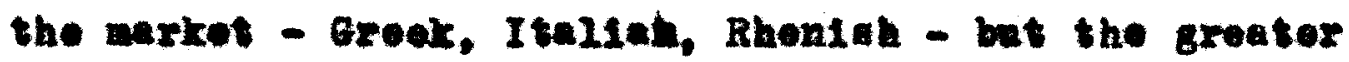

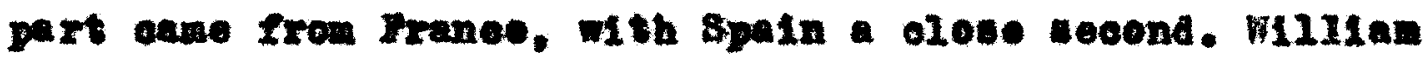

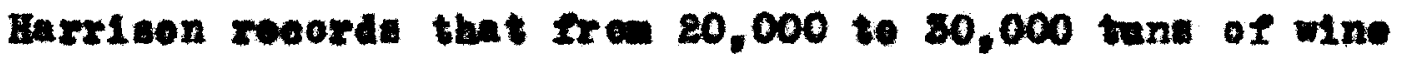
were Inported renxy to quenoh the thiret of his rellow conntrymon. This inolnaed oleret, white, rea, Drenoh. ote. Whioh enented te Ilfty-elx corte, aooording to the regione where they oans alse thirty kinde of Italian. Groatan, 8paniah, Canarian, eto., whereof rernage, oate-

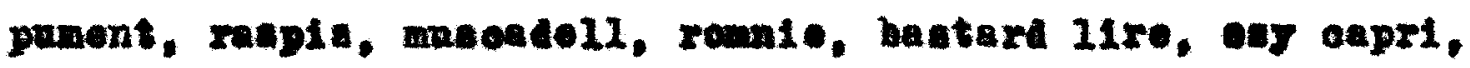
1ary. and mimeng, are not leart of ali acoompted of. becaues of theit strength and valour. ${ }^{2}$

Aleo mixtmres anoh as moath or notheglin. hipoeras. and other bereragea were bremed in the bome in addition to

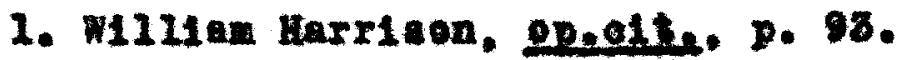


ale ande from walt, which alght be termod the national Arink. Howerer, Ainoe enrly in the oentary whe the wee of hope was introdued fro Mlandors, adaing a distinotive

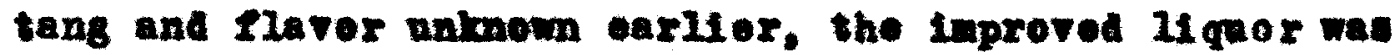

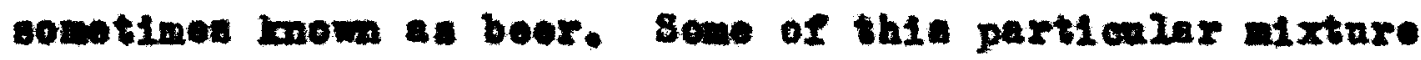
browed in Maroh and neod at noblemen's tables, was oalled Maroh beex," 1

I'II sond the a oeld capon a-field and - bottie of Maroh beor. (7., 111.636$) .2$

Al. browling wat almost an common an aotivity of the hounohold as tho baking of bread. Farrison along with his wite's reelpe for the fand ale, Bived the quantity made - three bogahead or ten soor gallons or wore - which

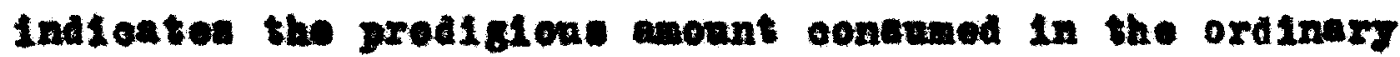
hone. Ale was Iroely glten to joung ohildron, although whe was rigoroutly kept from then. Youth was probably med Ires a reolpe similax to the one townd in Sir Koneln Digy'a oookbook. The Closet

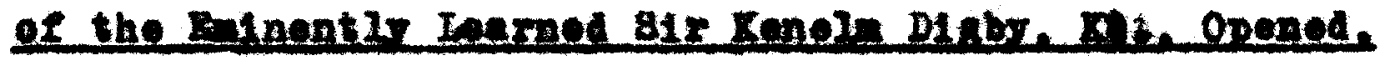

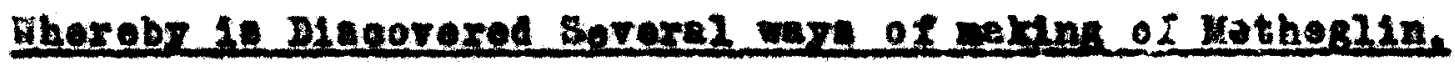
Bndex, Chersy wine, oto.

Take three gallone of water, a quart of hopes, If it be not itrong onoegh you may add more; boll it

1. Jamen Shirloy, The Iadr of Pleanre, op.o1t., (I, 1, 296 ).

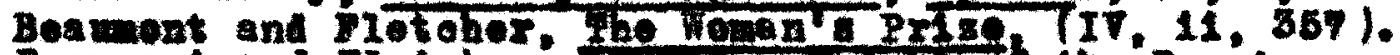

2. Beapwont and Flotoher, Drafl. Karght of the Burning Reatie. 
apaes an honr and sone it rery oleen; then take it

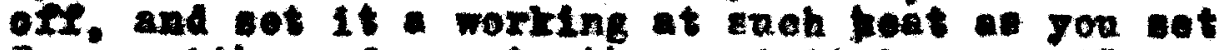
Bect, at be geol yeants then pat 1 in a runaler and at three day ond aran it ont in atene bottles. inte oresy one pat a piese of rimon-peel, and tro 010res. It is only pat inte the randier while it worksth. te aveld the breaklas of the bettien. 1

Ifpoerag, orten ued as a irink t wodalnge, is

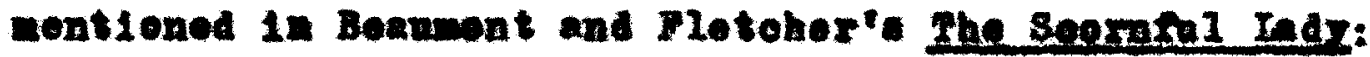

Wore the rosenny branoher atp't and al1 Tho uppoores and cekes ate and drent off

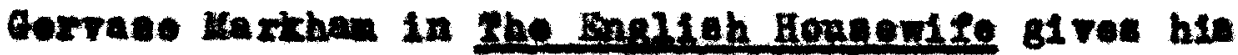
reolpo for naldus "Ipoerae:"

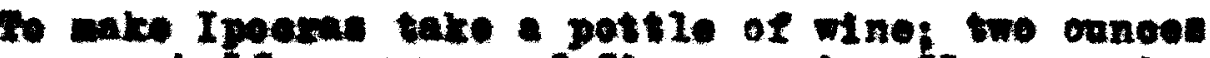

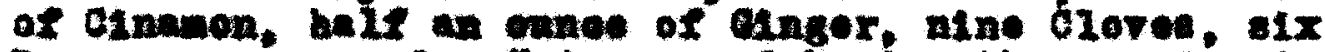

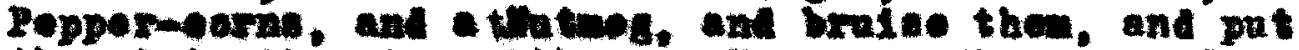
chen sute the wie with sobe Rosenery nowert and so

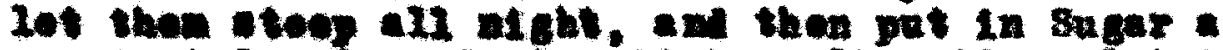

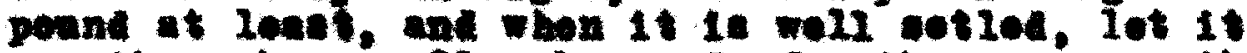

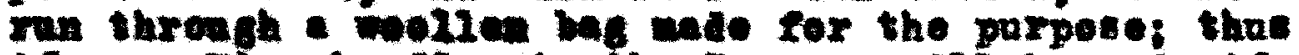

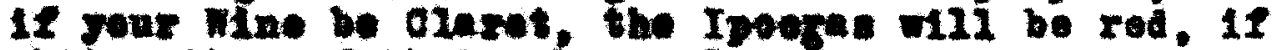
whe. then of that eolent alie."

Markhan's realpe is pratiogly tho gave as that

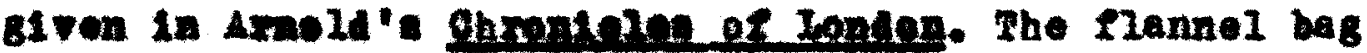

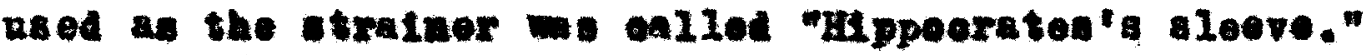

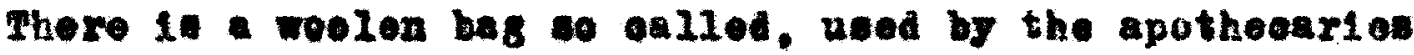
to etrata orrap and deootion for olarifiention."

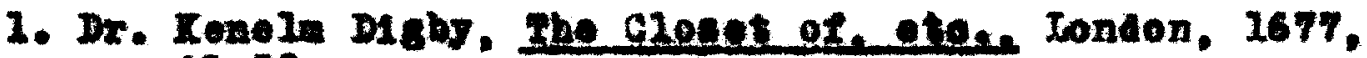
D. $49-50$.

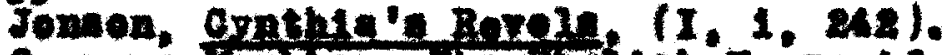

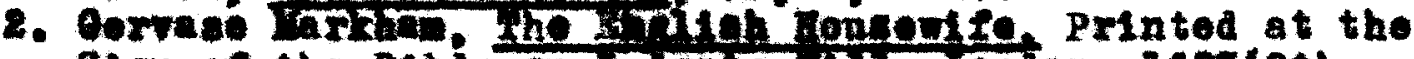

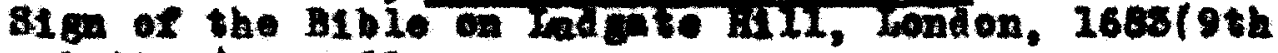
printingl. p. 60.

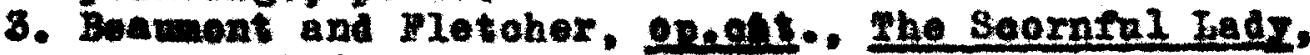
note p. 146 . 
Wine wa natprelly a more ariatearatio irink then ale ox beer. "Good quitekenting whe that will wake you oaper." 2 wa cerved in the loving oape at the groat

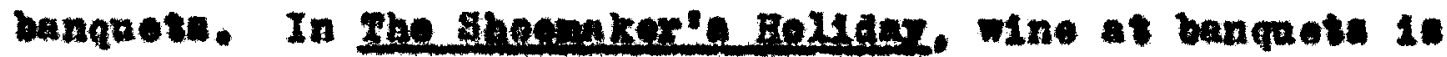
wonts onod:

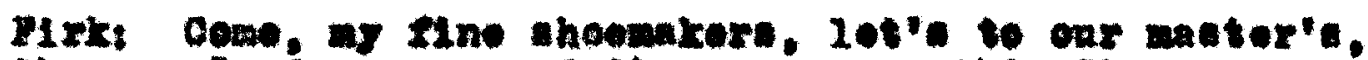
tho new Iord ayer, and there wager the shrovereoseng. I'11 prealse jou wine apegh. (v. 111.76$)$.

Awong winot mentionod in the playe are Inpriwas. charnico, batico, 8 neat Allegant, 8 mobaline, and barnt-

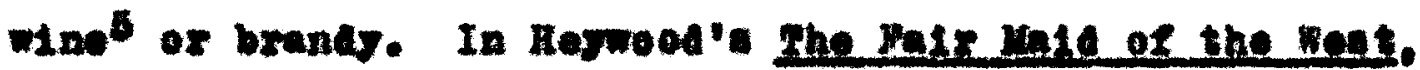
c1en, the rintnox'a apprentlos, exfers a variety of wines to hie onetonens

Ion are neloces, gentlowon. What wine will you

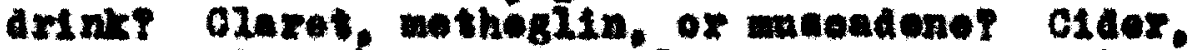

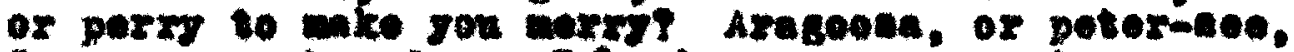

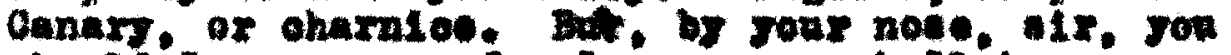
honld lowe cap of anleses: jou hhali have onp of the bet in coramell.

If you profor the Ironohann before the Ipaniard, you bilil have of ther her of the doep red grape, or the pallie white. You are a protty tali gontieman: ron should 20re high oountry wine: none but alorke and coxten lowe Gravel win.

$$
\text { (III. 17. 119-120). }
$$

Wine was often weabenod with aborants. In the

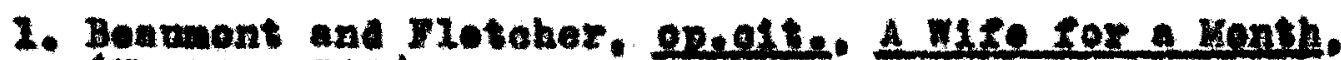
(7. 111. 242).

2.Dokiex, the Hencat there, (II, IV, 111, 262).

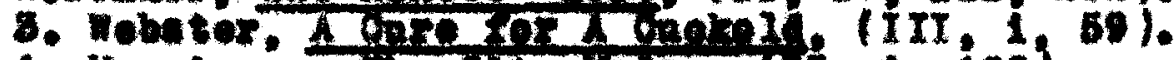

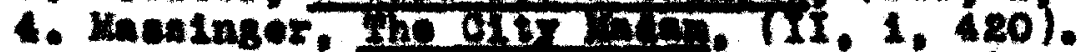

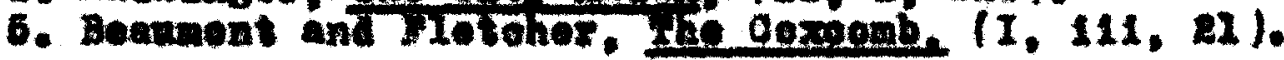


Qnaten of the Copntrr by Beanent and rletoher:

The wined be Inaty, high, and fall of epirit, And anbor'a a11. (III, 11, 888 ).

Ianb'a weol wat wade of ale with ougar, matmeg and the palp of a reasted apple, nopily a orab-apple. The nowe of this pepalar arint was derived frow the "Inefy looking paip of the apple, wioh oame burating through the axte during the roasting procens. "I

The origin of Lamb' wool was in the enot ont

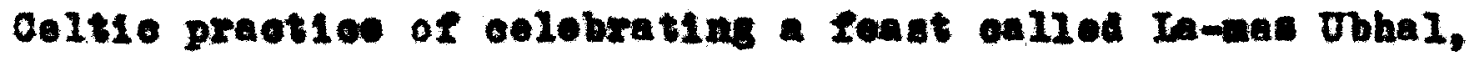
the dey of the apple fruit, when rosated applos were bruiced and alrod in ale, milx, or wino. 2

Iay orab in the fire to roast for lamb' wool.

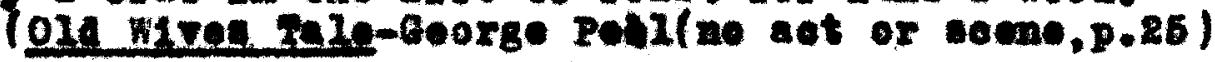

When roseted erabe wes in the bew, Then alghtly sings the stering owl.

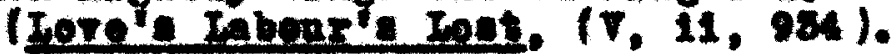

ind sowetine Inxik I in a goseip's bowl, In Tery likeness of a reasted orab. An whon the drinke, age tmat hex ifpe I bob

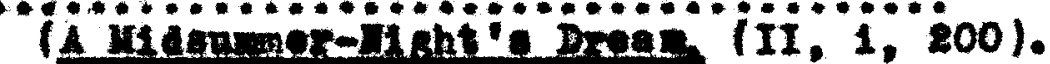

Sack is montioned requently. It was properly - dry eneot wine trea Spain or the Canariea. It wa

1. Ery I. Curt1s, onettie p. 288.

2. MNin Walah, carientiles of Popular Custon. Philadelphia, I6r\%, p. Th. 
nenally sorred in a orp noarly half full of angar, oo that the deinker perteok of ald of heady eyrup. Often 1t was hested and eessoned with opicos.

Wo'll arink a onp of sack together Phyelelane eay if doth prepare the appotite And otomab agalmot atnior.

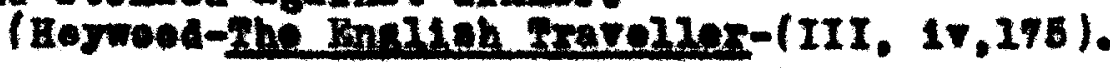

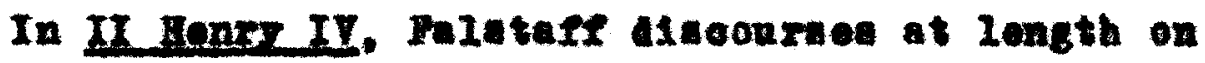
the noble qualitiee of sack; onding with the statement:

If I had a thougand sons, the first hwone prinsiplo

I would teach then should be,

To forawar thin potetions and to adiot themelves to beok.

$$
\text { (IV, 111, } 148 \text { ). }
$$

Saok wat often wae Inte a poset, arink inilax

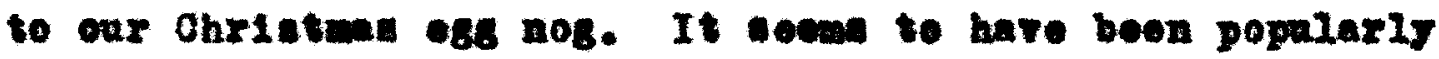

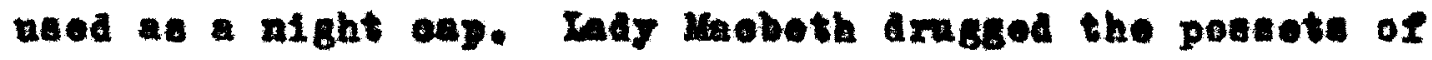
the greome on the night of the mardor of Benoan. ${ }^{2}$ paleteft in the yerry witen of Einger ordore pottlo of ack bremed Pinely:

Bard: Fith osen, Eix?

ralateff: 8imple of itaelf; I'2l no pallotaperm in ay brewage. How now! (III, 7,81 ).

A reelpe for a Saok-Ponset Iron A Ime Contlenan's Delight is quoted by Stannton:

1. Shakeapeare, Eabeth, enelt, (II, 11, 6). 
To Nake a 8eok-posect-take two garts of pare good Crean and a parter of a Pound of the best Alwond. Stanp them in the orean and boy, with Amber and Hulk thoreln. Then take a Plat of Stok In a bain, and cot it on a Chating-dish till it be blood warn; then take the Tolke of Twelve Bgen, Wth foux of then Whites, and beat then well togother, and so pat the Bege into tho sack. Then Etir il togethor oper the oon. till it be an

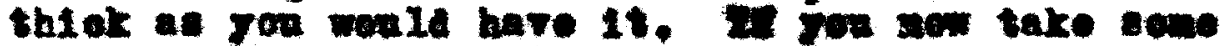
Amber and lnok and grind the sane quite anall of th angar. a natew this on top of your Penset. I prodie row that it $\mathbf{1 1 1}$ have a most delledte an pleasant tente.

110 remalned the great oomma arink. In Veboter's The reareat Doeth te the we11. Barangy Banoh, a batoborConder of old olothes lainge the pralues of ale:

well farea Bngland, where tho poor may have a

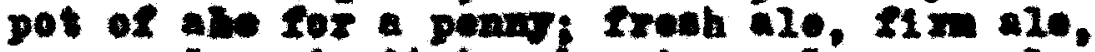

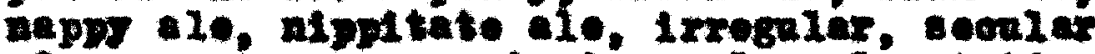

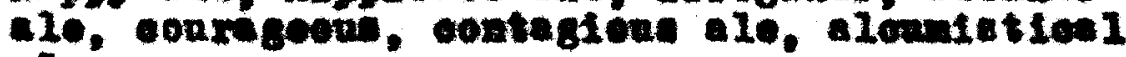
ale.

Oh! for one pot of nother Bungh' ale, ar ow wother's a10 to wash ar threat this alaty

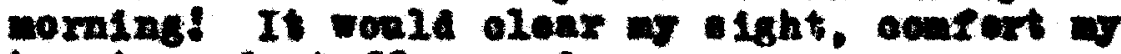
heart, and sture ar relns.......

$$
\text { (I. 11. 28s). }
$$

Whos the poorest olasses oorld not afford ale,

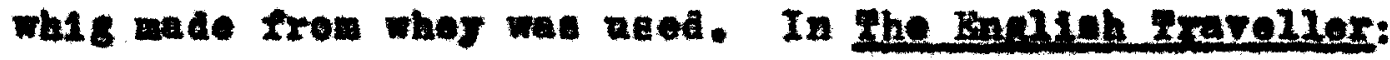

Reigna 1a, cervant: Adisa, 8004 ohocte and

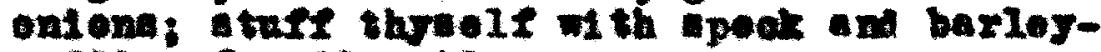
podang for algotien.

Drint whig and cour allx, whilat I ringe wo throat with Borteanx and oanary.

$(I, 11,162)$.

The age of fillsabeth was no freer eron ohloanery

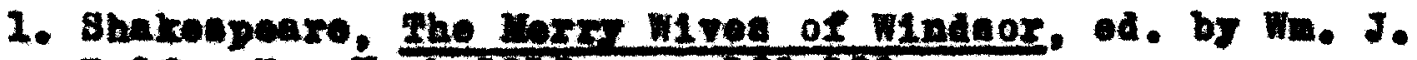

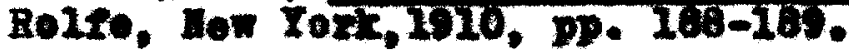


than is toley. Ifme or soap wa sometimed anrroptitionely pat Into the betton of a taniard as a triak of taptiora, In orter to nake old 11 guor loam whon drawn. In I Hony. IY, Palatare shouts:

$$
\text { Yon rogae, there's itne in this gaok. }
$$

A bharp ongtoner oonid outnit the triaky tapator by nwetohIng he opportunity and rubbing the inmide of his tankard with the old of rea berring, 2

An amsing seone oocors in Meter Becen and Briar

Bunner by Ereene, whoroln Miles inquires of the devil is there be not sood tippling housen in holl.
MIes: Way not a man hare a Iovty 11 ro thore, - pot of good ale. pair(paok) of oarte. a oningtag ploee or ohall, and a brom toast that wil alep a white wainteont on a ong of good drink?

Der11: A11 this yon wy have there.

M11ea: I mon hell in a hot place, and men axe marvellens dry, and moh drint is opent there; I vould be : tapater.

Dorl1: Thon she 2t. (1. 11. 297).

Which woone wonld indieate that Blisabethan Ingland oonid not fanoy a satiafaetor axter-11fe wi thout drink.

Lany oustom were obmorved an part of drinking In this poriof. Gellanta were partionlarly oxtravagant in

1. Shakespeare, I Henry IV, ed. by Wm. J. Relfe, Now York, 1910, note p. IB8, Cotgrare's W1te Interpreter. 
their toasting of friends and atutreases.

A toant? here's to your wenoh!

(Beament and Bletohor. The Coxeant.)

(I, $\mathbf{7}, 21)$

Prioking a rein and inking the blood aleng with the wine wa coneldered rery fashionabie. Fhis on oten oocure in A triet te Catoh the 010 One by Madeton:

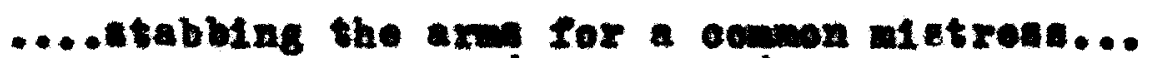
(7. 11, 81).

In Groen't Invares:

......... opos veln to arink a rull boelth to Jon. (note po soo, Exthie's Rerele. Jena on).

Alwo in Gethe' Brele by Jonson:

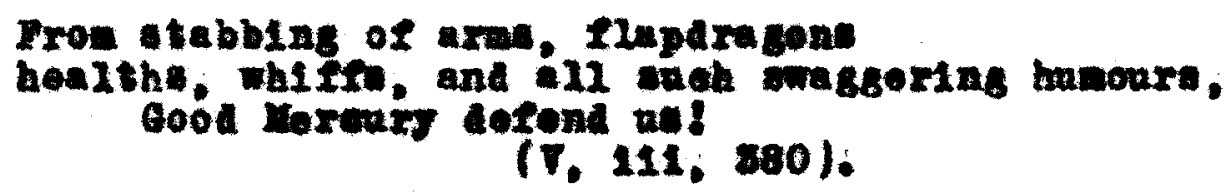

Flaparagone or amaperagon refor to on old arintIng rite anpposed to have orlefinated in Holland, whorela

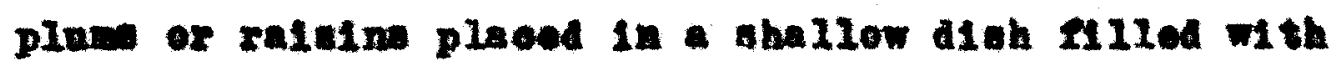
11ghted opirita, wore dexiropily satohed with the morth.

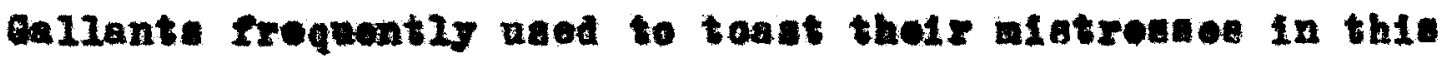
may:

Q17e wo that Map-dragend

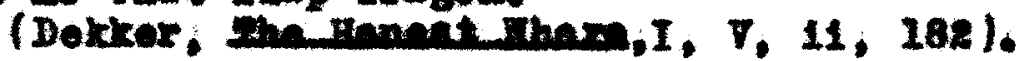




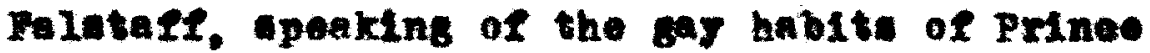
Henry and Posn. refert to this oneton ox:

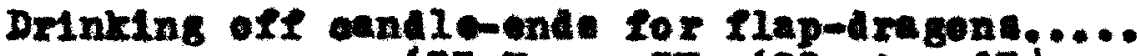
(IT Rent IV, (IJ, 1\%, 67).

\section{Ale eara Costara in Iere's Labot's Logt:}

Thon are canter swellowed than a Map-dragon. (7. 1. 1 ).

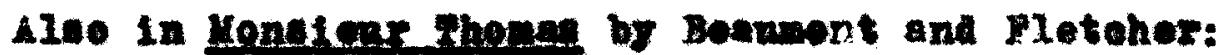

Caroue. har health in and1-ande. (II. 11. 46).

To arink enper-naging, aocoralng to note Iron

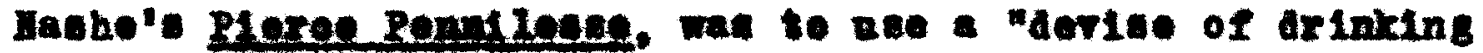
now oone ont of Ixanot whioh, ie ater a wa hath turned np the botton of the ang, to arop it on hid nalls, and

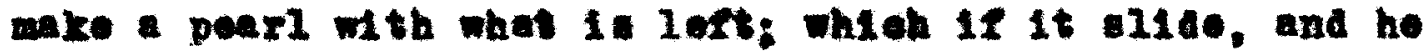
cunos nake it etand on. by renaen ther's too wnoh, he wet artut again tor his penseo."

In Dokkar"s 2he tomest whare, I, reforones is made to thit onstem;

.." "Wa" done gon right on ar thand nalle.

$$
\text { (I. } 1,22)
$$

Another spo of arinding fte wae apsy-ixeong of

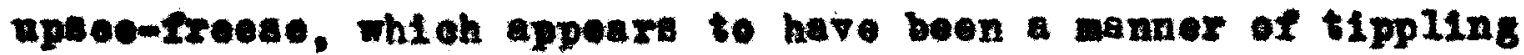

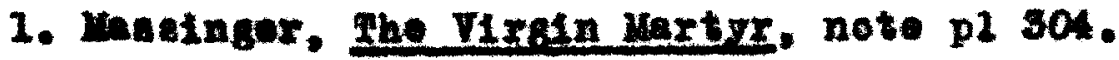


Iiported Irou Holland. In Ihe Rane of Inereen by Hegroed. Bratue ears:

Thon hast beon in the Gorwan warn; 12 thou

lorest ae drink upsee-freose.

(III, 111, 375).

In the Virate Harter by Philip Meninger:

Becobne 804 of brewed whe, npey-lreeng

tipplere and onper-naenim takme.

(II, 2. pp. 26-87).

And another reforonos from the Rape of Inarees:

Haceluna the gol of brewed wine and engar, grand patron of rob-pote, upay-renesy tipplers and onper-haterin takere; this Baochue who is head warien te Viatore'-bill, ale eonnor, major to all vietuniling-houece.

$$
\text { (IT, 1, 26). }
$$

In general the texw was used as an exphentem for tipeinome and 14 ofter need to mean bard arinking.

orten callents tholt in arinking pledges. In

Weatrare Hoe by Dekkox:

47 weter and 91x Gosiln are gaseling:

Ther are dabbling together fathom deep. Tho wight has

Drank vo woh healthe to the gentleman ronger, on his knees

That he bath alnost lost the wee of bis lege.

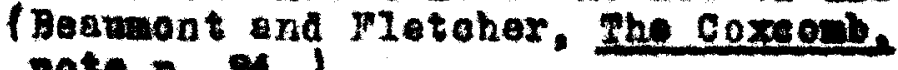
note p. at.)

Again in Warmion't Ant2onary: 
Drank to your hoa 1th, whele nighte in Hippoeres. Upon ar moo, with wore religton

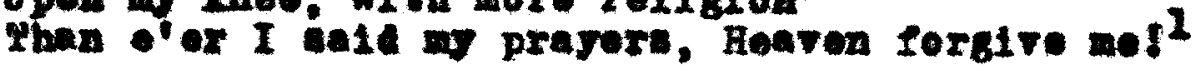

In The Honot Whore by Dorkor. Bate ask:

112 you 2011 on youx narren bones to drink this boelth?

$$
\text { (IV. 111, 264). }
$$

The wastil-bowl nontioned in wang of the plays. partimiary in the arinting cenge. was a loring onp that

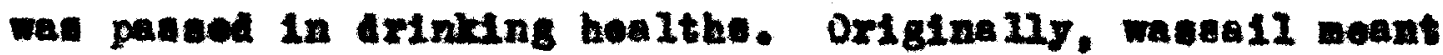
a pleage drunt between triende. The word 1s now applied

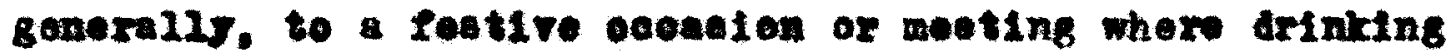
and teasting are the onder of the hour and alao to the

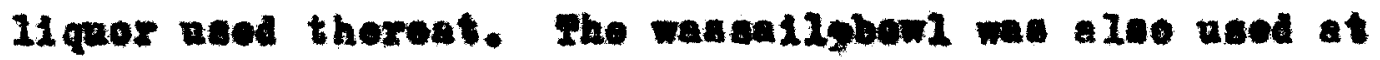

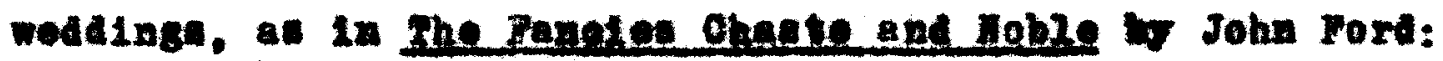

The wasea12,bowl

Hark, the wedding-jnili th!

With a bride-oake on at life to graos the maptialn!

$$
\text { (I. } 111 \text { ). }
$$

Sometinew the bowl wae of eliver, but more often 18 was mate or maple and wa ealled a masor.

Cod Lrates, overmouns. STer-bonourea, orer ewn. Stalmed with bloed or lates grapes, In a thounand Inety ahapos. Baneo upon the ascer' brit. In the arimen 14 goor swin; Prom thy plenteons hand algine. Lat a river ran with wine.

1. Beanmont and Pletoher. The coxagnb. noto p. 24. 2. IbLa, Velentintan. (V, 711. 496 ). 
Af we Iind exproasions involving food in the play. there are also terme Involving arink. Among the wany torw for intoxioation was "qo pleck a halr of the same wolf

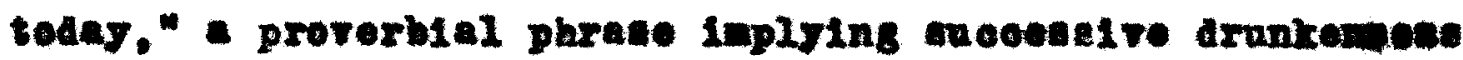

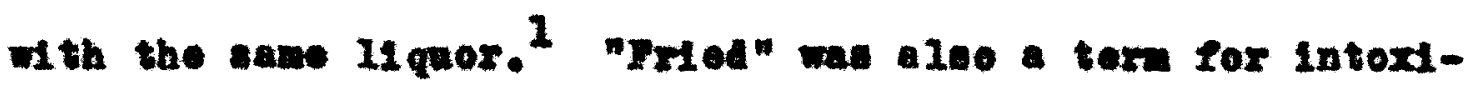
oat10x; at in Beawnont and Floteher' Hit Mithent Monex:

$$
\text { Ion'se mied ne soundis. }
$$

"Pareel-drank" meant half-dxunk, a tern whioh bae boon explained in oompeotion with the pareel-gilt ealt cellart. John Motchor bas used this expreasion in the Chances:

She is pareel-arant. (IT, 111. 00 ).

Also in the sane plar:

She in a 11ttio glated over. (IV, 111, 28).

Alonse in The reaneat any:

And Prinowlo is reeling ripe; where ghould thoy Find this grand ilquor, that hath gildod thoup $(1,1,26)$.

To be "roxed" alse meant to be arank. In The Retr Uald of the Im by Beamwont and Motcher:

1. Ben Jonion, op.olt. Bertholenen zaiz, note p. 19. 
Tonr Datohnan is Iexed. (II, 111, 482 ).

The common invitation moaning to "bare a drink"

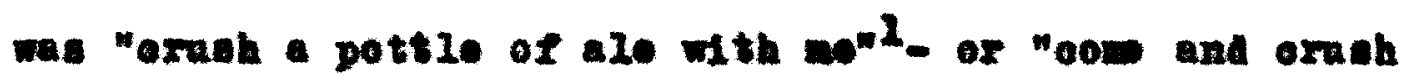
a oup of wine." 2 And noedican to any, theoe phrased are found with great Irequeaej.

A wot graphia desoription of a Peant with 1 te atbendent carouning in giren of Ioang Geraldine in The Ens110h Grareller:

In the holght of their earoualng. all their braing Warmed with the helt of win, Alecoure was offered of ablpe and atorm at cea: whon sudenly

Out of hie glads wilanose, one coneelves

The roon wherein thes quaffed to be a pinases. Hoving and noatingt and the centused notwe To be the manaring winde, conts, mariners: Thet tholr unateadrast footing ia prooeod Fron rookting of the restel: this coneelvel, Beob one begting to apprehend the danger, And to look ont for befoty. 'Mr.' ael th one, 'Tp to the math-top. and discorer: he Climbe by the bod-poet to the tader, there Reports a turbulent see and tempent towards,

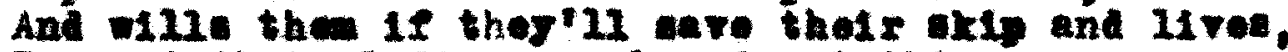
To east theix lallng orerboerd; at this AII fall to work, and hoist into the etreet, As to the sea, what next oome to their hand-

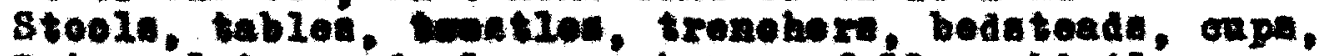
Pote, plote, and glansed hore a foilon whistice, Ther take hin tox the bohtewain; one 11 en etruggling Opon the 2loor, at he man for 11fo: A third takes the bate-r101 for the cookbont, s1te In the belly on's, laboure and rom. His oar the stior wh which the fideler played;

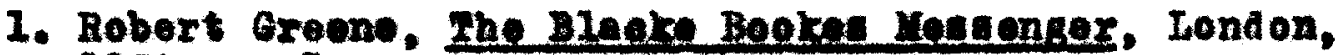
1984. p. 6.

2. Sba kespeare, Ronee and JnIfet. (I, 111, 86 ). 
A fourth bestridea hie follow thiniting to seape An ald Arien on the lolphin's book.

St11l tumbling on a gittorn.

$$
\text { (II, 1, pp.176-177). }
$$

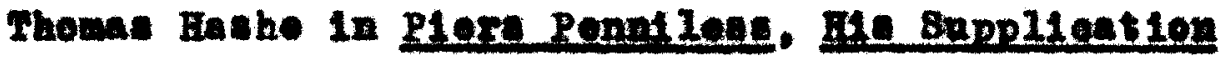

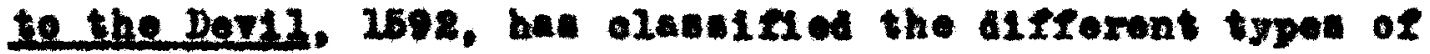
arantarte of his dey:

Wor have we one or two kinds of drankards only. but of ght kinds. The flrot is ape drunt, and he leap and elnge and hollowe and danesth for the hearoni;

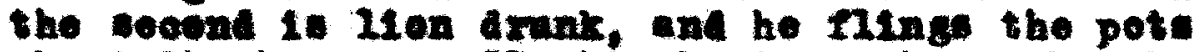
about the hoves, on II, his hosteas whore, breaks the glase winkows 1 th he cager. and is apt to quarrel Wth any man thot speake to hin: the thi ri is owne

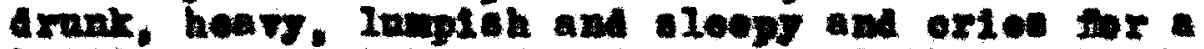
21tt1. wore drink and fon more olethes: the fourth 1. boop irmat, wiec in his own oonoelt, whon he eamot bring forth the right word; the fifth is nandiln dxank, whon a felion will woo for kindnese

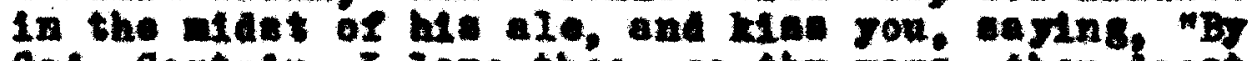
Cod, Captain, I 10ve thee; go thr way. thou deest not think so often of ne an I de of thoe. I wonll(lf it pleane cod) I comla not love thes co wall an I cofl and then be petil his ringer in his ore

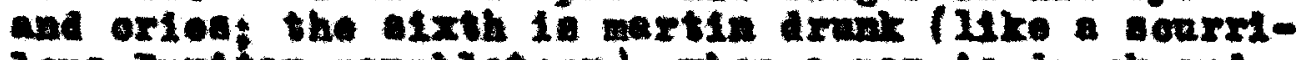
Ious Puritan panphiotear), when an is drunk and arinke himele aboer ore ho stir, the sorenth is goat arruk, when in his dxumbemeas be hath no aind but on leohery: the elght is fex drant, when he fo arefty drant, as maxy of the Datehnex be, that wil never bergals bot when ther are arrent. All these apeetes and more I bare seen praotioed in one ocmpad at one ofting, when I hare been pexitted to reva in sober amonget then, only to note their soveral bunoure. 1

An an ald to the tipplor, there appeared in 1594

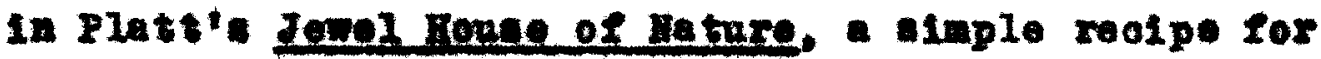
thwarting arrankomoss: "whe porson if advieoth to drink a good large aranght of alind 011. for that will fat

1. G. B. Herrison, Fngland in shakespeare'a Dar, op.o1t.. pP. 130-181. 
epon the wine which gon shil drink and supprese the epirite srow ascenalng inte the brain." 1

Thronghou the pleye are conge in pratse of the "nut brom alo" of the mere fabhioneble wine, and there 18 no doul that real rolsterere anking morm in real taverne and real oountry selk at play lifted thelr voloos in these refralns. Woat of thowe jolls remes are echese of the happs, well-nokriched life of the working elasece, but on oocasion a gentlomen breake into acng. For the tarem ma a denoeratie plece a drifk a leveling intsitation.

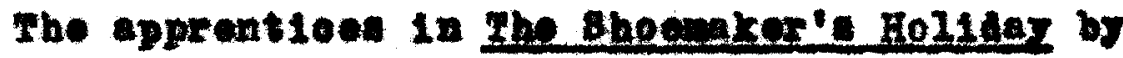
Dokker alng the showakert' song in houor of st. Fhgh:

Cold'a the wine, and wet's the rain, gatnt ingh be oxr good speed:

III Is the weather that briageth no gin, Ior helpe goot hearen in noed.

From(paes) the bem, the jelly mat-brown bowl, And hore, ulne wate, to thee:

Lot's sing a dirge tor seint Hagh' noul, And dow 18 morritel

Rean a lown, hey down a down Hoy dorky derry, dewn cown:

Ho weII done: to mo let cenel RIng, compase, gentio jog."

In the rught of latts the volaters oing:

Sit. coldier, olt and sug, the round is clear, And ooox-a-10041-100 tella is the day is noar. Pheoh tose his oan, nntil his throat be wellom. Drint, langh, and elng; the volder has no followt

1. G. B. Harriaon, The Rlicabethan Journal, op.01t., pp371-2.

2. Dokker, on alt. (7. I7, 78).

8. Baumont and Pietoher, op.01t., (III, 1, 314-816). 
To the a rall pot, 11 t 10 lanoe-prisade. And when thon hat done, a pipe of Trimplado:

Oux glase of 11 fe rum wne, the vintner skinke it, Whilat with bis wife the rollo eoldier drinka $1 t$.

The drume beat, enaigne wave and cannens thanp it; Oor gane 1e rake, and the beat hoart doth trump it: Baeh tos his can, natil his throet be mellom. Drink, laugh, and stagt the solaler bat no fellow.

I'II pledge theo, a oorporal, were it a Inagen; After, wateh flereor than boorge all the dragen: What blood we 10ke it th' tom, wo gein 1" the tuns: Furr'd gown and llat hate, give the wall to gane. Beoh tosa his ean, until his throat be mellor, Drink. Iungh, and alng; the colalor has no follow.

In The Sun' Dar2ing by John Ford is Felly

Sonk, after cach verse of whioh 18 was oustopary to arink: ${ }^{1}$

Oastamay eare; he that Icres eorrow

Ion hene not a day, nor on bay to-morrow:

Howey is tresh, and ho that wiIl apond 14 .

Iet him arink morrils. Portune 7111 aend it.

Herrily. marily, merrily, 0 , hol

Plag $1 \mathrm{t}$ oxt atifty, we moj not part so.

Wne 1: a hara. It heats the bloot too;

Cowarde It will am, if the wine be good too;

Quickens the wit, and eaken the beok able;

Soorm: to mbat to the wetoh or conntable.

(Choras, wrr12, merri15, ato.)

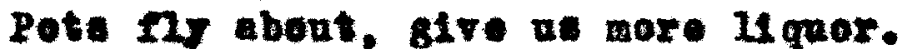
Brethera of a rout, onx bralna w11 Ilow quioker; Rapty the oank: coore up, we care not:

7112 all the pote egatin; drink on, and opare not.

(Choru, merrily, merrily, ete.)

2. John Pord, ghett., (IV, 1, P. 152$)$. 
In the Spandeh Garate by John Flotohor is a song by the ourate' neighbora:

Iot the bells ring, and lot the boys sing, The roung laster aktp and play:

Let the cupe ge round, tIII rovnd gees the ground. our learmod old tiear wil stay.

Let the pig turn merri1y, merr11y, ah, And lot the rat goene awing

Jor verily, verily, verily, ab, onr vioar this day binil bo trin.

The Atowed cook shall orom, cook-aloedie-100,

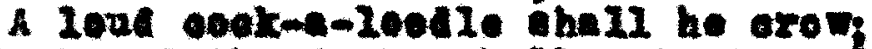

The cuak and the drake thall ent in a Iake of oniens and claret below.

Orr wirea ball be noat, to bring in our neat To the our mont noble adviner:

Aha palns ohaII be great, and bottlea shall oweat. And we onxelve wil be wiser.

Wo'II labonz and swak, wo' 21 ka and w'll drink, And ti the shell bene thioker and thicker:

woll1 enII to oux plingh and got ohildren enow. And then shal be Iearned exd rioar.1

Relle or the Bloedr Brother contalue goomen's

refraln:

Come. Fortune's ahore. I eare not who 5011 her, Wonld offer to israngle a page of the eollex. That chould by his onth, to any man's thinking And place, have had ederenoe for hia arinking; But thus bhe doen otili whon ohe pleases to paiter Insteal of his wages, she glves hin a halter.

1. Beanont and Hetohor, ep.e1t., (III, 11, pp. 279-280). 
Chorne: Three merry boy, and three mexry boys, And three merxy bere are we, A ever aid abiag in hompen string tinder the gallowe treefl

The ook in thic save play is ise not allent in his arinking:

Drint today and drom all sorrom. You silall perbepe not ao it tonorrow, But while jon hare 1 t une rour breath: There is no arinding after denth!

Wine worke the beart up, wake the wt. There in no onre "gainet age bet it. It belps the head-aoh, congh and ptiste. And 1 is 16 for 011 discases phote.

Then let we ewdil, boge, for onr health; Who drinke well, loves the commonwealsh And ho the wiIl to bad 80 sobex. Jile with the jear. Hil in ootober ${ }^{2}$

Praine if oung to the "mot-brown alo" in rexees estributed to meters:

The nut-beown ale, the mut-browa alo, Futs cown all artint when to is stalef The toast. the nutweg, and the ginger Fi11 mate a ching man a cinger. Ale give a bufot in the head. But girger nader-prepe the brain; When ale would strite a trons nadead Thea atoeg toapers 1 it again. The nut-brewn ale, the nut-brom alo/s

1. Beamont and Noteher, oneft., (III, 11, 190)

2. IHA. (II, 21, 158).

8. Goorge Reraben Potter, Glizabothan Veree end grose, Hon York, 1928, p. 168. 
One of the wost rolliading of the ronge is a pattern after whloh nam of our Kentuols movntaln ballade are ades

Beok and side go bare, go bare, Both foot and hand go oold;

Bat, belly, God and hoe good ale enowgh, Whether 1 t be new or cla.

I oannot eat but little moet. 4 stomich is not 8004 ;

Bat oure I think that I gan drink Whth him that weare the bood.

Phough I go bere, take ye no eare, I an nothing a-oole;

I stuff of atin go tall within of jolly goed ale and old.

1 love no roast bat a nat-brown tonst, And a laid in the elre;

A 11tble bread ahmil do mo bteal Hroh bread inmt desire

Her frost nor snow, nox wind I trow. cen mat wo if $f$ woll

I as so wrapt, and thorought lapt, of jolly good nle and bie.

And 1 is wifo that as her 11 fo Loreth wo 21 good alo to coek. Full eft arink sho. 1111 je as wee The tears ran do bu her ohooke. Eren ath she trowl to wo the bowl ITon an altwe mo shold:

And ealth, 'sweethenrt, I took ay part of this jolls good ale and old.

And let thow drink, till they nod and blink dren as goed follows ohould do; and thes aball not fise to have the blisu cood ale deth bring wen to And all poor gunis that have soour' bowle, Or have then Instily trowled,

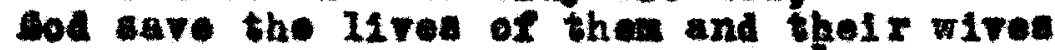
Whe thex they be young or old. I $(\operatorname{sti11}(\varphi)$ or Sterensen $(\gamma)$.

1. George Reuben Pottox, gneat., p. 160. 
With all the loasting of the ITth oentuxy. obesity mat have been goneral, bat there is little on reo ord to abow that it oanked any undue ooment. Howeror.

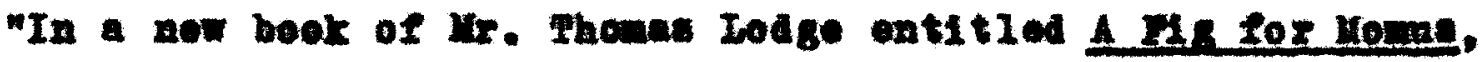
being andry satires, coelogues, and epistlen.....there is an opsotic to a lady that wrote to him anding both the canse and the romedy of puratnens and fat, Giveth this renedy:

Wroh oltting, an long abatinonoe from eare. Drinting of olly wined our tat propare; Hgge, white moat, pottage, de ineroute the seme And bring the maxing body out of frome. Iot therefore men grown fat by gintton (For to the reat in nodi olne I apply) opon a reln; or if that ecen toe oure Dee euppinge, and oft rabbings overmore. Live in that air wh oh 10 both hot and $\mathrm{Ary}$. Watoh weoh, and aleoping littie, hardis 11 . Waik woh, and tear, and tablo in the man, Deilght to rile. to hatk, to hent, to man; Drint littlo, gargartee, ny groscer lood, Ox 11 aome aben a hare or partriage good. Ioed nodestly thoreen, and 19 ho hath Sone oxoms to spend, go orten to the Bath!l

Dovertheless, he is of an opinton that fatnose is

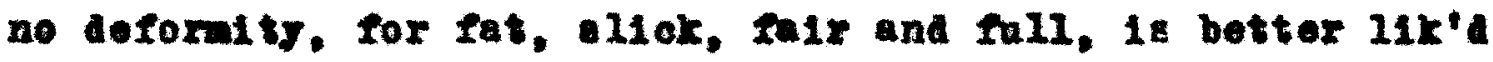
than Iean, Iank, opare and dul1."

In thic same otrain is the sentiment expressed in 01. Fortunates by Dekkex:

1. Q. B. Herrison, A Seoond Bll zabethan Journel, op.oit. P. 28.

2. Ina, 8 . 28 
Anaelogie: ..0 lean alot makes at wt. Shodon(eervant). I had rather be $a$ fool and wear a tat paif of ehooked

(I, 21, 805). 
CHAP2RR IT

GOOD AWD DRTEK AS A PART OY

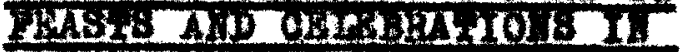

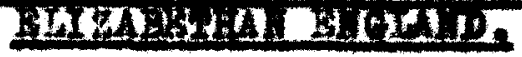




\section{MOOD AIID DRIUY AS A PART OY

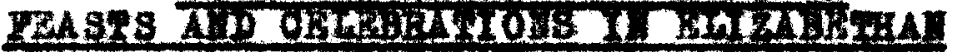 \\ Alctulle}

Prospority. Iong periods of peace, exceltenont ereated by the discovery of new lande acrone the sea, and the rapid obanges oansed by Inoreasing oonta et and trade Wth othor nation all contribeted to the jogous, onrotree apirit that ebaraeterised the time. A foeling of fele de flre permeded the ontire country, from the poereat to the noblest oftiren. At no tine sineo this period bes $21 f 0$ in lingland boen so gey. Ho later age has orowded se mang hollany and oelobrations into the ealendar. Along w th the rogular ohroh holldaye ware font1rals that had oome down Irom pagan times. These added to the ordinary reaste woh a aoompanted weddings, ohristenInge, and other oelebrations formed a coneiderable maber. One pertionlariy intereating hollday was shrove Treaday, known an Penoake Day, whioh narked the beginning of Lent. Daring Flisabeth's time, the rellglone aepeot of the hollday loat ite impertence, bet it remained a great 
ocoarion enpoeially for sohool-boys and apprentices. The eating of paneskes probably beoane a eustom of Shrore Tuesday becauge it wal nooesgary for erery hougebold to we all the greane and irippinga on band before the boginning of Ionton tating. Therofore paneaked relgnod ouprene. They ware almay turnod by teselng then in the a1s and eatohing then in the pan with tho nnoooked side downart. There wal great rivaly as to who conld most adroltig toad them.

This old onston still aurviven in come of the sohoola of Hagland. Boye olooted from every form try to atob a paneake that the chool oook teeses over a bar in the sohoelroon. The boy rotrieving it unbroken is given a prite by the sohool heal. 1

In Dokrer' the Shoegaker'd Hollegr, the shoenaker approntioen hear with joy the ringlng of the paneake bell:

A11: The paneake-bell ringa, the pas-oake belld Friilil, a hearte!

Fixis: on bravel oh oweet belll o delleate paroarea!

Open the deore, w hearts, and shut np the windowa! reep in the hories. let ont the peneaken!

The epprentioes hasten to the now great hall where the now Iord nyor is giving a feast. Mirk oontinues to expilt:

Drexy Shrove-Tueday is onx year of fublice: and when the pewenke-bell ringa, wo are as froe as wy lord-major: we way ahat ap oux shope. and make holiday.

$$
\text { (7. 11, 76). }
$$

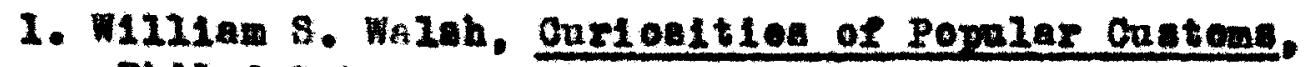
Ph1ladelphta, 1897, p. 884. 
In antiolpetion of the foat that 1 owating then at the Lord Hayor's fant, Mizk gloata:

0 manteal bell, at111!...... There's oboer for the hearons: ronison-patios walk up and dow piping hot. Like sergeantis; bees and

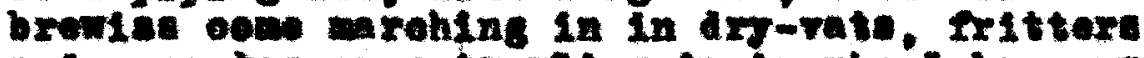
and pracalos oene trowling in in wheel-barrow, hon and oranges hopplng porterw-bakkets, collope and ogen in sentties, and tarts and onstarde come quavering in belt-ohovele. $(7,11,79)$.

Jokn Taylor, he Water Poot, in bie Jeok-a-Iont. 1680, vigoronely attacka Ranoake Day:

Conmonly before nine thore is a bell reng onlled the papock-boll, the sound whereol maked thomeands of pooplo distreoted and forgettri of ther of nanners or hament 10. Then thore is a thing o I'd whoat'n nowre. whioh the sulphory, neorcmant lak oooked doe aing 20 whth water, osg aploo, and ot hor tragloall,

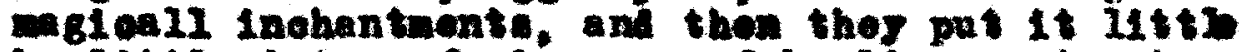

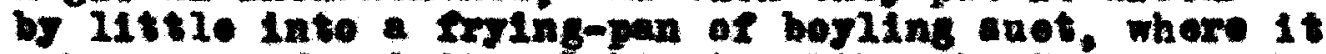

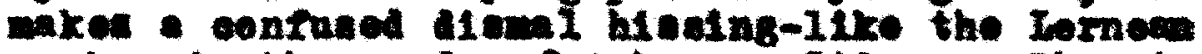
snakes in the reede of Aohoron, 8tix, or Phogetenunt11 at last, by the akil1 of the oooke it is trantformed Into the forme of e flap-jack, whioh in onr tranalation is eall'd paneake, whoh ounlone inoantation the 1 gmorant poople doo dovoure very Breedily..... wherexpan thefr wite formake then, and the runne starke wad, agsembiling in rou to and throngs, moberlense of angorermable nubern, with noolvil consotions. 1

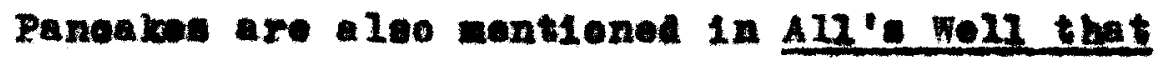

Enda fill in the abawer of the olown:

113 an

A panoke for shrore-mesday.

(II, 11, 26 ).

1. W. Walnh, opotte, p. 804. 
Shoop-shoaring day, partionlarly in conthera Ingland, was the ocoesien for unoh foasting. After the bhoaring a plentiful dinnor me provided for the ehearere, thelx briends and the villagers. In Foser' Hre phndred

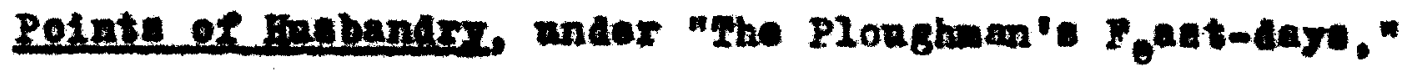
are the following line reforring to the feativity:

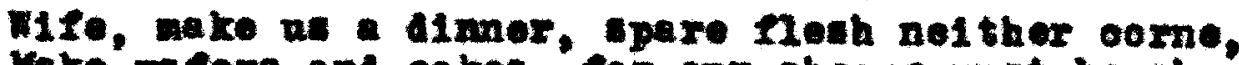
rake mefere and oakes, for our ahoepe wat bo horne; At hoepe sheuring, net ghbor none other thing erave But good oboere and weloome Ilke nolghbonrt to have.1

The olow in The finter'a rele lists the suppliod the are to be bought for the sheop-ahearting fears:

Tat w sees what an I to buy for our aheopohearing reant?

Throe pound of agar. Plve pound of ourrante, $100,-$

What will thic alater of uine do with riee?

Bat ay fattor hath vade her pistese of the reast, and

She Inge it on. She hath made we four and wenty noagegnge

Por the hearers, three-man-eong-men all, and very good oned.

in............

I wat have safrion to oolonr the warden plos; naee an dater?-

Ione, that's ont of ar note; nutwegn, Beven; a raoe or twe of ginger.

Bat that I mag bog: fonr pound of prunes, ant Al man ra ialan of the onn.

$$
\text { (IT, 111, } 26) \text {. }
$$

Chrlateninge ware alwaye attended with wal

foating, and it apparm to hare beon the onston for the

1. John Brand, Observations on the Popelar Antiguitied of Great Britain, Iondon, I8T4, p. 34. 
womon to carry oway as men of the confection as they ploaned. In The Batohellox'n Bangent. Dekker:

What oost and tromble it w111 be to have all thinge fine agalnat the Christenting Day; what otore

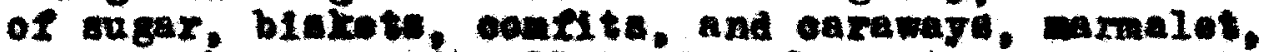
and marohpane, wi th all kind of weet suckere and apertinous banqueting state, with a bundred othor odd and neodioa trifie, whioh of that time wat All the pookete of deinty dames.

It was orten oustemary at ahristeninge to prosont the baby with apoons, usnally apontle epoona, so called becanse of the flgares of the Twelve Apentled carved on the tope. Sines opoons and caulis oups forma almost the onit artiolen of plate posnenand by the middie olagees, they were oone1dered handeom prosonts. In the Hagnetle Iadx by Jons on, Compase eapa:

I cene to invite your ladrahip

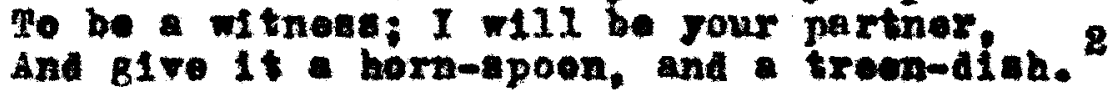

And in Bartholonew Pair:

And all this for the hope of two apostbepoon.

$$
\text { (I. 1, } 884) \text {. }
$$

Bridemalon, Irom whioh the nord bridal ia derivod, are wedaling celobration montioned in wany of tho playe. Cakes and whe were brought to the ohnroh and plajed

2. H. T. Stophenson, Blisabothan Roople, op.oit., p.289. 2. Jonson, The Kagpetie Iear. (IV, 111, 95). 
- part in the wodding onremony. In The Fanotes chaste and loble by Ford appeare the following:

Eark the wedding-jellity!

With bride-eake, on ay life to grace tho mptia ia:

$$
\text { (II, 11, } 400
$$

And in Jena on' The Yagnette Iasr:

A wen that' bid to bride-ale, if he have eare

And axink onough, ho noed not war his stake. $(1,1,188)$.

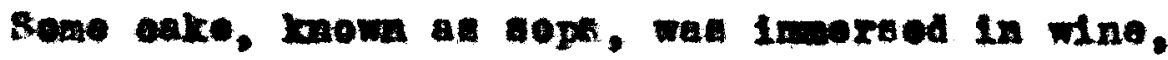
and the oup pasged to the bride, to the groos and to tho rest of the company imbedately arter the ooreanno. The

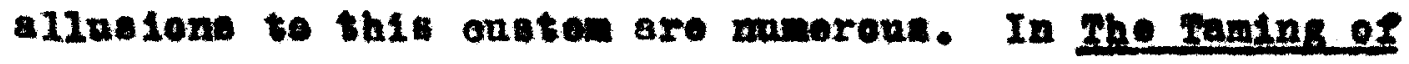
the shree. Crode dosoribes the wodding of Potruchte and Katharino:

But after many oeremonios dene,

Ho onlif rox wine: 'A health! quoth he, al if Ho had been aboard, oaronsing to his nated After aterm: quate' ofs the masoadel And threm the cope all in the sexten's taos. (III, 11, 171).

And In Boanent and Flotohor's The Sogrnful Iady:

If my wodding-amook wore on

Were the gloren breught and given, the 110 enoe oome, were the rosemary branohoe dipt, and all The hippoerse and eakes ent and drank off.

$$
(1,1,1 \text {. }
$$


In Dekker's Sat1re-lanttx:

Bring wine and eaked. ${ }^{\text {are at onr ohuroh }}$

Christmas was the great day of the gear for fonst-

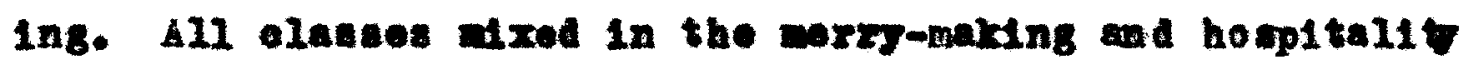
was universel orer the Iand. An Jinglist oountry gentiemen of the 25th and 16th oentreles always hold open house, and troe dajbreal bis temants and nolghbors fllled the ball.

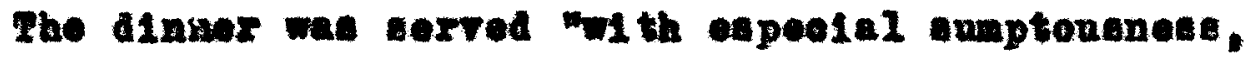
with great attention paid to the 'alahos for ahow,' an

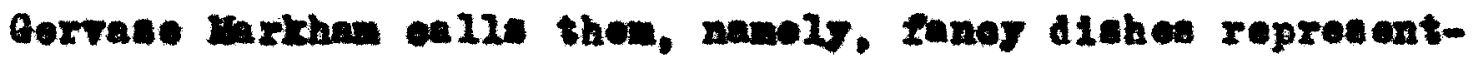
Ing objeote got up with great olaboration, but not meant to be oaton, $m 2$

Inaeparable tron the Chrtatuan feast was the boar's heaf, sexved upon a great platter garniched with rosemary and bay leaves. Qmeen's College, Oxford, hat atill mainteined the old orston along with the alnglng of the anolent carel that has aooompant ed the bringing in of the boar's head for countleas generations;

The boar's head in hand beer $I$, Bodeok' mith bays and roemery; And I pray you, or masters, be merry. guot ostit in convivio, Capa Apri aeroro Reddens Iandes Demine.

John Brand, ep.att., p. 136. H. T. Stophenson, op.eit., p. 169. 
The boar'a-hear, as I nnderatand, I. the mrest aloh in all thie ind. Whioh thus bedeok" with a gaj gexiand Iet ue eerrire cant ios. Capre Apre texero Heddens lonate nomino.

Onr etoware hath provided this

In benour of the $\mathrm{x}$ ing of Blise. Which on this day to be nerv'd 19

In reginenti atrito Caget Apre daforo Readmen Ienden Domkno.

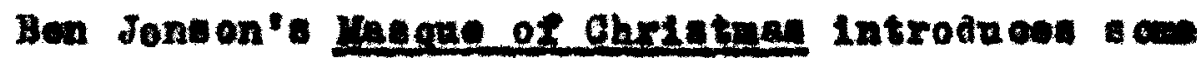
of the traditiona oomponents of Chrietwas coasting. "uinoed PJo" is present, as is the "Waesel" or Iortng-onp. "axest with ribend and rosemary." Jenally the bow held

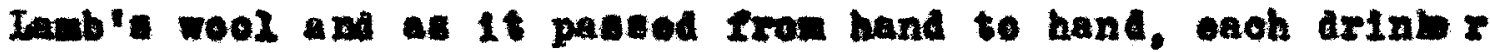

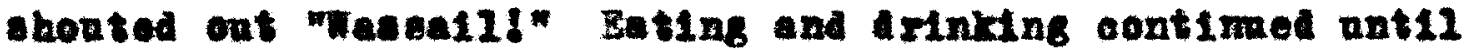
tar into the night, and 18 is reoorded that nang of the guoste were round aneng the rushes in the norning.

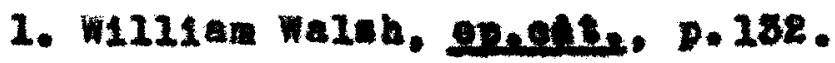


-

CONCDUSTOL

- 
The tmportant relo ylajed by food and axink in Alisabethan IIternture was probably a refleation of natlonal interest in the andeat atiminted by importatlone of now ediblos, goneral prouperity, and poriof of peace is witoh the altisonry had time for thonght upon

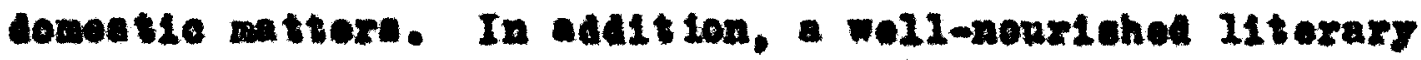

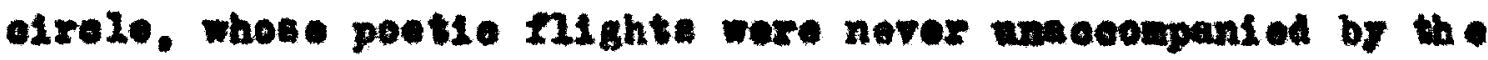
conalderation of oreature oparerte. ple jed an important part.

In this period there are for rooorde of otarving writere of any inportanee. In fnet, sone probably mattored

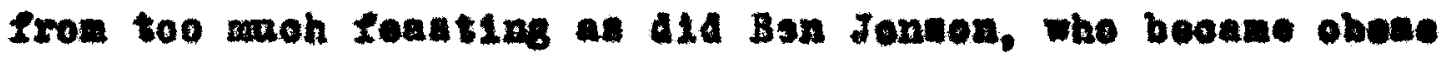
and gonty from oror-1ndulgenoe. Iren Robort Gronn, whose

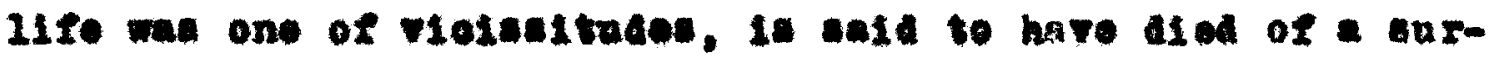
rolt of rod-horring and Rhoninh wine. Poxhap thore is a atronger conneotion than we can guong botween the flumerim of the realistlo aram in the 16 th oentum and pational plomy. Perhape wow grain of trath ile in the woxth of a wodern writer that: "Mo jusen anst be tod generonaly. Good wate and and wines fire and invigoxw te the brain. Thes heat the Imgination inte conding forth dassling and gll ttoring boant.

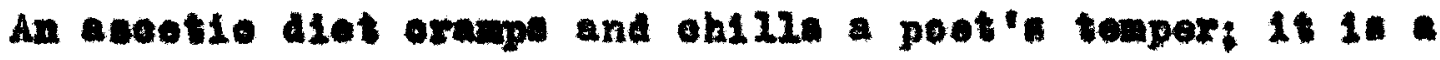
trost to the fanar, and nipe the flower of poetry in the 


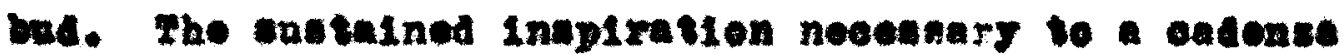
of divine poetry in aften found in "two mutton-ohops wellpoppered" and bogateat of Canary-wine. $n^{2}$

In the cane temper wrote John Tarlor, the Water Poet, in 2680:

A Poot by mator an nover bo rized, By the fules of the grope the Nine is inopired:

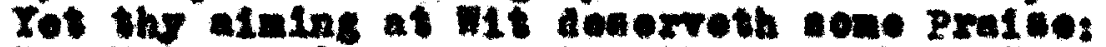
bat Water ne'er nerriehed the Imuxel or Bny.e?

Whaterer be the reletion botween the "onpor-linme"

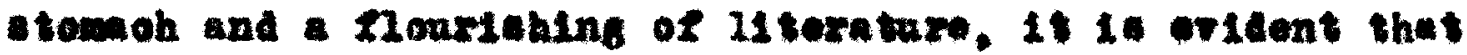
the generral aix of 101 de clure that is the porvading obaracteristle of the oomedien of thit time. conde coareely hare existed under the rotgn of tho Puritenc. The "eat. erink and be merry" philom ophy of the Klisebothan perted would undoubtedis bave beon ohilled by the attitude temra I1fe oxpressed in Hra. Cromwell'a pronounowent that "the

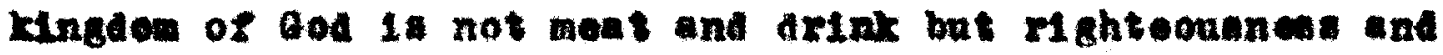
peace." A generation saturated with "mat-brown" ale oonla

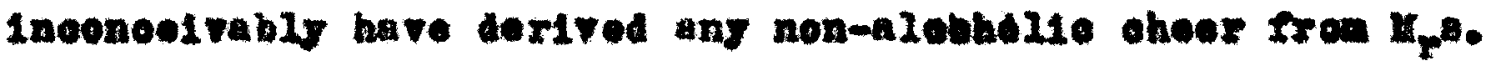
Grombell's panace, a problbition boverage oenopetod from toast, water, and fow onrrants.

The mans ceoned in the ime, in the tarerne, and

1. Drron Steol, Q Bare Ben Jenunt, Iow York, 1988, p. 218.

8. IH. D. 116 . 
the many conversations about eating and drinking all gave an aotuality and reraimilitude that wated the drase of this period fathral pieture of mannera. "Infinitely geoful fron a aramatie point of vion ia faniliar reforenee, the eweoping up inte the belly of the dialogne of the everyday realitied of the Blizabethan bookground. Pood and arink an farniture of shakeapeare's play fand oven more so the work of wang of bis oontcmporaried I, are all BIfabotban. Titanis leop on a bak of wila thyes, - oreanopled with Rnglish woodiand Rowora; Jullot'a corpue

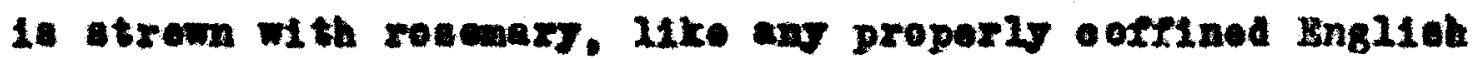
ma1den's: and the gartienors in Rlohare II bind np that Fucer noweomer of frulte, "the angling apricoak. inl

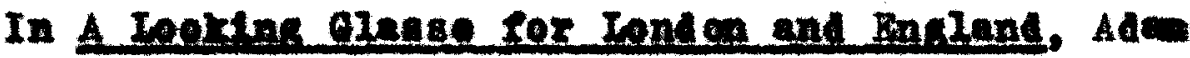
at Mneroh, brahing uhoulders if th Osean, the Prophet, chate of ale and red-horring with wntard. In the Honeat

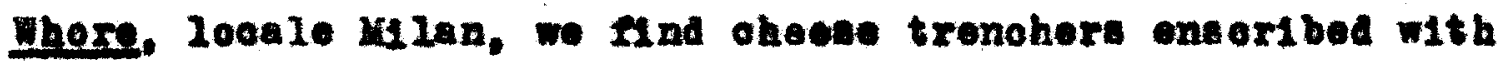
poesios; and in the Repe of Inoreae, in Rowe aro taverne oalled tho Mitre, the KIng's Eead, and the Star; and the orfes of the oity lnolnde onch an angliolun as:

Bread and moat, bread and moet, for the tonder pritoners of Iowgate.

True to the tradition of Bnglish oomedy ainoe the days when the firet banorous charaoter appenred in tho oraft

1. Harleg Orantilie-Barker, A Coupanion to Shakespeare Strales, Ion Tork, 1084, D. IS8. 
play, and when there wa reeorded one of the firat roforenoes to Britioh tool in arane.

Oayn: Haxetom, (heareat thou) boy? Thor 10 a podsag (pudding) in the pot.'

14 is the mumble foIx that are portrayed the more realietleally. It 18 the eervante - the pantlers, the oookn, and the waitingmen - the voldiera, the apprantioes, the yooven and the tradespoople whose convertation so oftom to mo to the engrosing abjoot of eating and drinking. Or 1t 10 charmetore of the paralte type, taken orer from the comodie 'el art1 - Greedy of businger's A now nay to

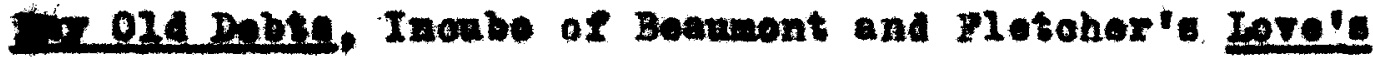

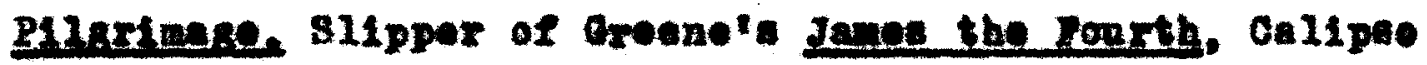

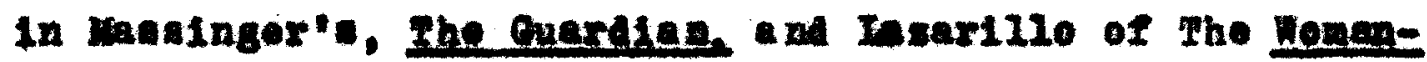
pater by Beandont and letoher and othere - who noror riae abow the thought of a Iaden bable.

"It Ia Intereating to note for "the deteli that ennbles us to reareate the Bll sabethan soene we ge to a dosen of other writerw than shareapeare...... Where the ordinary Bli anbethan writer is topieal in the sitnation, oharaoterIsation and alaloge of an ontire moone, Shekespeare 18 toploal only ont of hil supernatty in an selde, a imile, an 1mge, a Honith, a jeat. Whereas the contemporaneone

1. Joseph Quinoy Adam, Chler Pre-Shakeapearean Drames, Iow York, 1924, p. 995. The RIIIng or Abel, Glover of waker1old. 
10 of the vory body of suoh a writer al Ben Jonson faleo Dokker, Iorwood, and othere 1, it 18 with shakeapeare largels a matter of copurable incleont, 1

In Dekker'e The shoengker'a Rollder is a dotailed pieture of 11fo among the jouxmeyon and apprentioes on Pancake Dag. In Shakenpeare, Shrove Tueatay is morely wontioned in a inile: "Fit as a paneato for shrove Tueeday." In taking the work of shakepare as whole, there it ittie ovidenoe of woh Intereat in food and axink, aave on the part of the gourmand Falataff. Perhap Sheketpoere spoke of himalf in the worde of Iongaville, a loxd of Mavarre, in Iore'a Iaboric Ioat:

W mind aha12 benquet, though the body pine: Fat pannoher hare $200 \mathrm{n}$ patea, and delnty bi to mate rioh the riba, bat bankrapt quite the wital (I. 1, 26).

Honot in reconstrueting the gattatorte I life of El1 gebethan lingland, we turn lose orten to Shakeapeare than to somo of his conteporarios - writers who have given ne to "fal thrul a ploture of the manners of the day that their

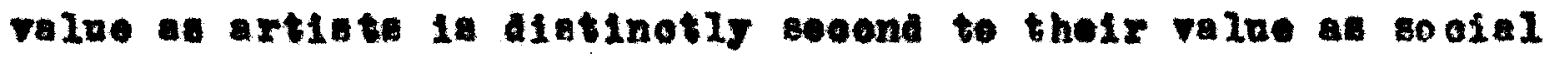
doounente. ${ }^{2}$ It is to their wide neo of the oentemporary 1dion of 11 to and their rocurrent referonos to food and drink and oustom perteining therete, that wo are indebted for a priceleas ing ight into a part of the goolel life of 16th centurs inglana.

1. Harloy Grant1110-Barkor, 0p.01t., p. 187.

2. Ible, p. 187. 
MrghogRartr 
Adans. Joeeph Quinoy, Ghief Pre-Shakedpearean Drapag.

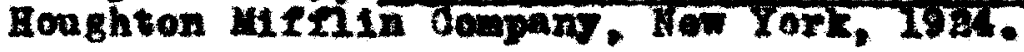

And rewa, 3. C.. Brealeut, Dimner nnd toa, Hawed class1-

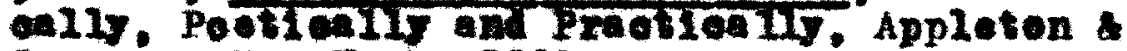
Company, How Tork. IS69.

Bakerv1110, Oharl ce Read, BnRlith Hienents in Jonwon'e

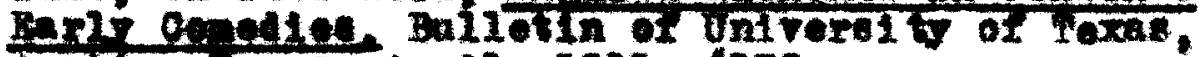

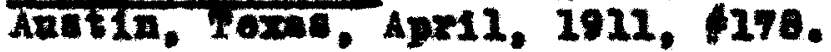

Beanment and plotoher, The Fory of, Introduction and

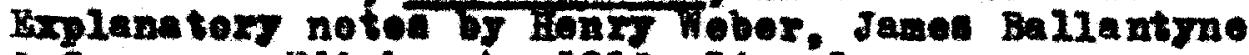
- Companj, Jalnbargh, 1812, 14 volumes.

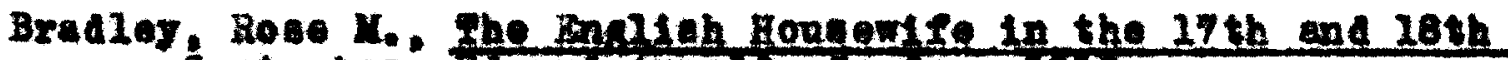

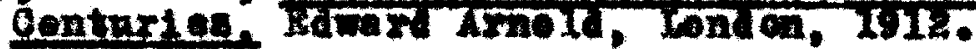

Brane, John, Obserration on the Pomelar Antionitles of Great Britum. Henry 0. Bom, wondon, Ib6.

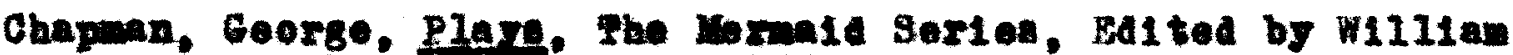
ton Phoips, Mon Tork. 185.

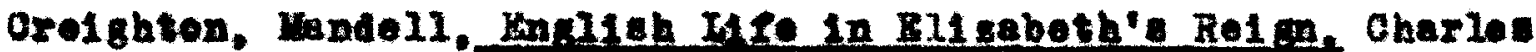
sortbnex, won rort, IEV.

Curt1s, Mry I., Garland of Sene and Stery. Alija Beon, Ien York. TSBI.

Davis, Hlian 8., He in Filsabethan Dare, Haxpor s Bros.. How Tork, iove.

Dotkex, Thomas, The Gele Hornbeek and the Belman of Ionden. J. H. Dent a Compans, Londen, 180t. 
Dokker, Thome, The Drenatie Resk ef. John Poarson, Iondon, Iftb.

Dokker, Thoese, The Plarpe Pamphlete, edited by P. P. Wisen, Grarenton Pron, Oxford, 1925.

Digby. S1x Kenoln, The Clonet of the Folnently rearned s1x

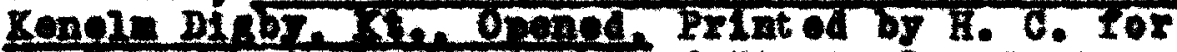
i. Brown af the wot-ent of 8t. Penin, London, 1677. (8xa odstion).

BIlwanger. George H., The Plearnres of the rable, in Aecount

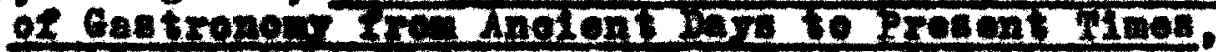

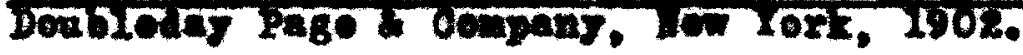

Ford, John, Horke, Jamen Toovey, Ionden, 1859.

Gerare, John, Jeaves frop Corerde Horbal1, 1697, Honghton

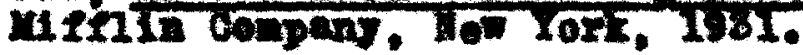

Grami1210-Berzar, Harieg, A Oonentes to Shakespere

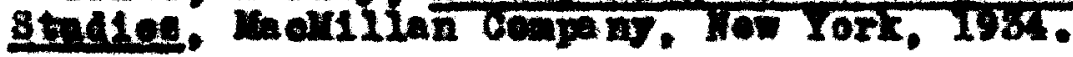

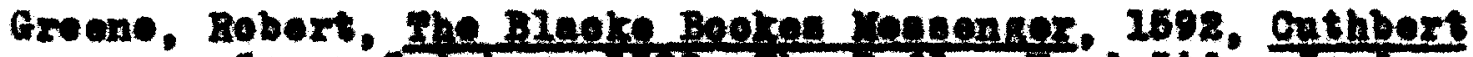

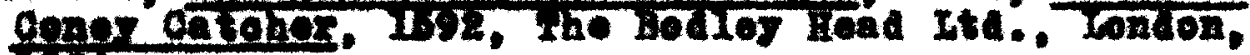
IIST.

Groene, Robert, Plere and Poes, The Clarendon Preat, 0xtord. 190\%.

Heokwood, Irederiok w. Geod Cheer, Sturgie and MaIton, Won Yoxk, 1921.

Harricon, H111an, R11 sabothan knglant, 1577-1598, odited by Lothrop Vithing on, the ititer $\$ 00 t$ PabliahIng Company. Ite., Conden and Howeastlom-on-Fyne, no date.

Harrison, G. B. Bnsland in Shakeareare's Dar, Haroourt, Brace Coupan, Hon York, 1928. 


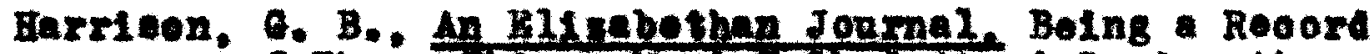
of Those thing rod ralked dbout Daring the Ioa 1601-1694, Conmopolitan Book Corporation, Iow Tork, 1989.

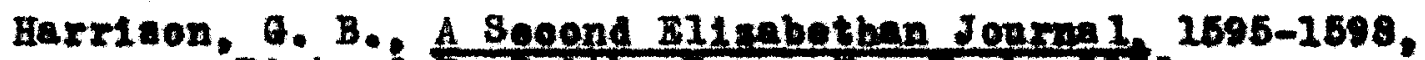

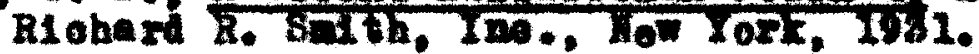

Horwood, Thomes, the Beat Plara of ox Dremet1ats, od 1ted

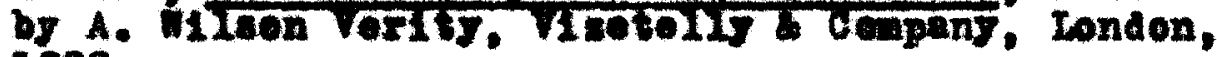
1888.

Jons on, Ben, Werle. W. Buinor Company, Lond on, 1816.

KIng. Dr. Willam, the art of deokery. In Inttation of

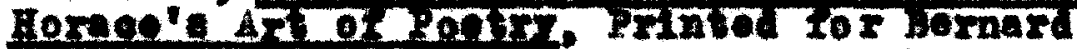
IInte t, at the croen kase between the two Temple cated in Fieet street, Iondon, $1709(9)$.

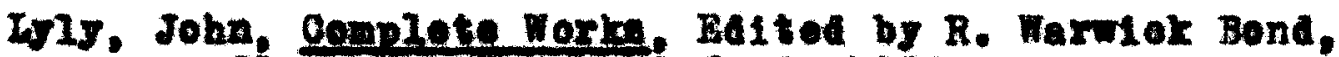
ciarencen Frods, oxfora, 1908.

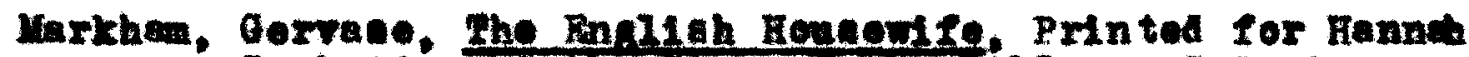
sambridge at the sign or the bible on ted gate H111, London, 26as ( revined).

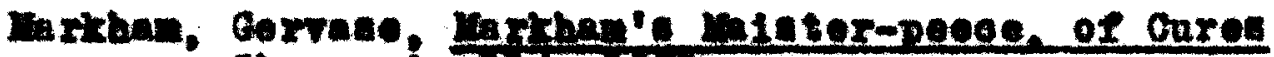

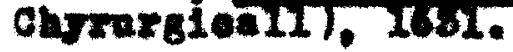

Marlowe, Christopher, Plare, The Kermald Series, edited by W. I. Phelpe, IOF Tork, 1895.

Haselnger, Phillp, Plaze, W. Bulmer and Company, Lond on, 1818.

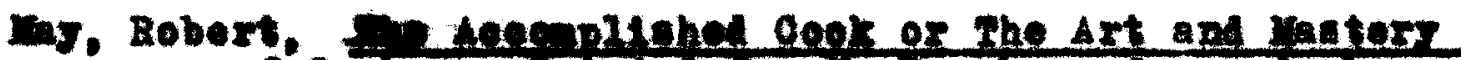

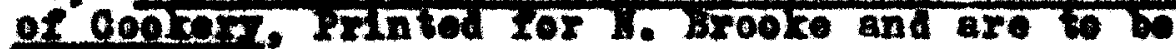
DoIf DI die. Arobor at his ahop nnder the Bral of st. Danstan Chureh in pleet Stroet, 1671. 


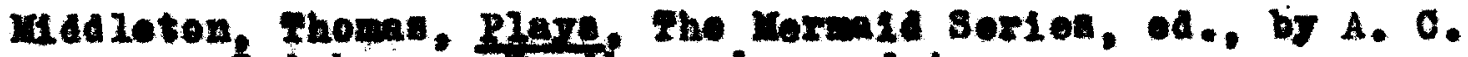
Eninbreme, Soribnore', no date.

Poele, George, Chief Shakeanarian Dramatiate, od., by Wa. A.

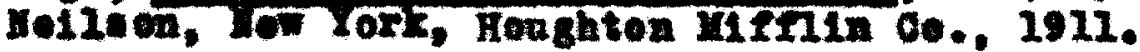

Potter, Coorge Rerbon, Hifrebethen Veres and Prose, Henry

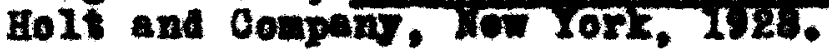

Rolfe, W11l1an J.. Shakeapeare the Box. Farpor and Bros., How Torx, I6:5.

Soott, 81r Waltor, Kennilworth, David Wokay Company. Phlladelphis, bo ento.

Shakespeare, Genplete Worts of, Grosett Danlap, Hen Torr. IJll.

Aleo:

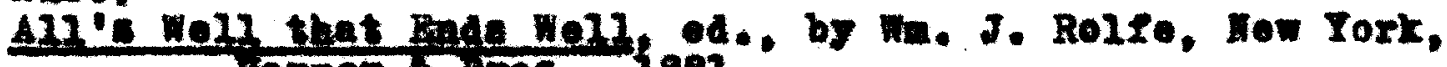
Larper or sroes. 1892.

Grobellag, of., by Wm. j. Relfe, Mow Tork, Amerioan Beok deapans, 1890.

I Henry IV, Wh. J. Roxfe, Amoriean Book 00., 1800.

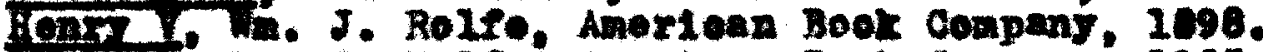

babal. Win. J. Rolfe, Amorioan Book Cempan, 1905.

Ort liven of vindeor, Amert oan Book Company, 1910.

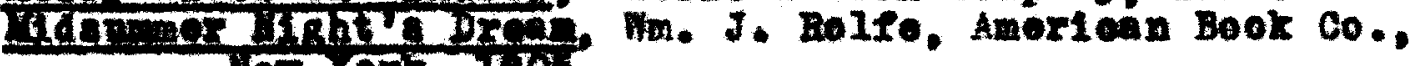
Iot rort, 1908.

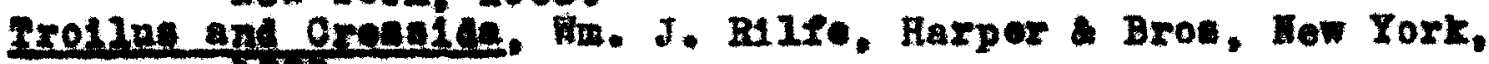
Ibla.

Inter'n Fele, Wa. J. Holfe, American Book Ce., Now York, 1098.

Stec1, Byron, O Rare Ben Jeneen, Alfred knope, How York, 1928.

Stophenson, Homy Thow, Blisebatban Reople, Henry Holt a Compans, Dew yorz. IFlk.

Stophenson. Heary Thow. Sbekeapeare' Londeg, Honry Holt Cempany. Hew Yort. IJU. 


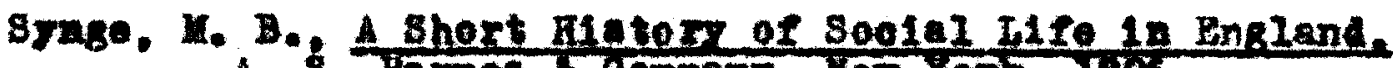
A. 8. Brmos Conpany, hot Yor, 190.

Tournenx and Wobtor, Plere. The Mo mald Serles, od., by

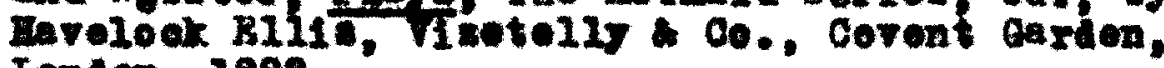
Lond en, 1808.

Ira111, H. D.. and J. 8. Mann, Sootel Ingland, Cassell *

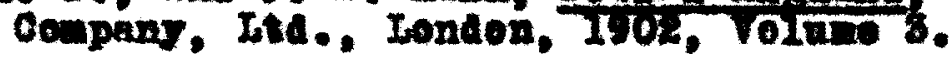

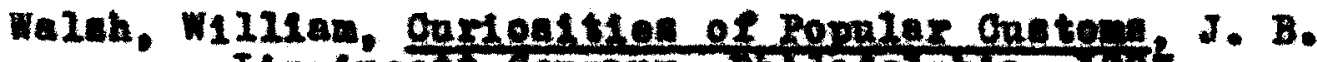
If ppineot cogpany, thitrolphi, 16 t.

Weboter, John, The Drenatie Norta of, John Rnosell Sutth, Lend on, 1667.

Wilnon, John Dover, Life in sheregreare's Bnglant. A Book of Blisabotwa Frose, at tho Unitoral 5 Preas, Conbrise, 1980. 